U.S. Department of the Interios

U.S. Geologjual Survey

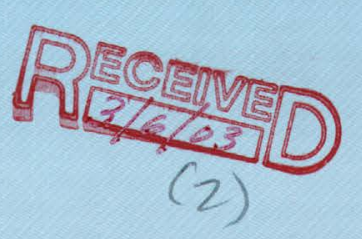

Catastiophic Debris Flows Jransformed from Landslides in Volcanic Terrains: Mobility, Hazard Assessment, and Mitigation Strategies
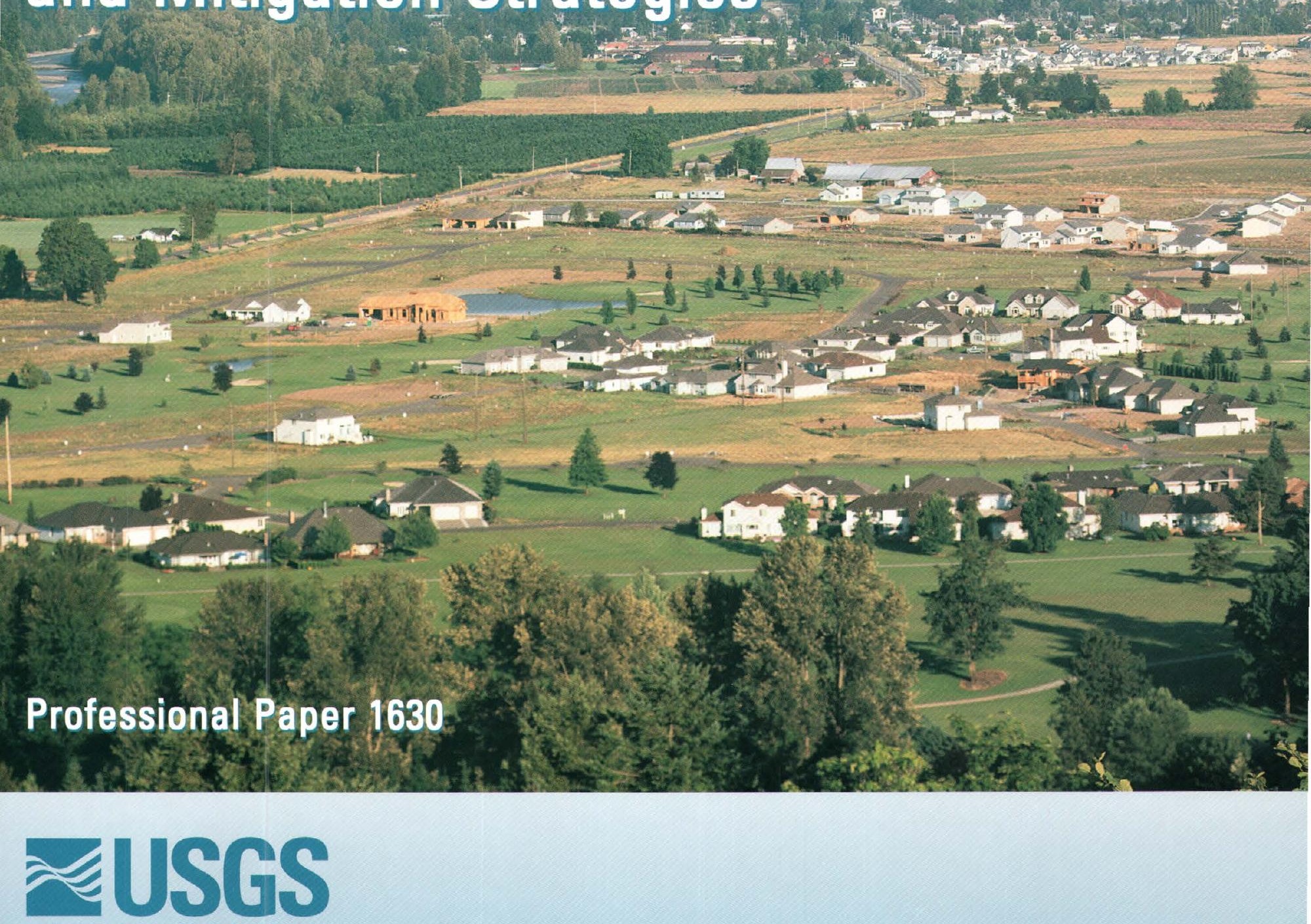


\section{Cover photograph}

Mount Rainier, Washington, with the flood plain of the Puyallup River in the foreground, 50 kilometers downstream from the volcano. The flood plain is a pathway for debris flows (lahars) from the volcano, most recently by the Electron Mudflow about 500 to 600 years ago. (Photograph by David Wieprecht, U.S. Geological Survey.) 


\section{Catastrophic Debris Flows Transformed from Landslides in Volcanic Terrains: Mobility, Hazard Assessment, and Mitigation Strategies}

By Kevin M. Scott, José Luis Macías, José Antonio Naranjo, Sergio Rodríguez, and John P. McGeehin

U.S. Geological Survey Professional Paper 1630 


\section{U.S. DEPARTMENT OF THE INTERIOR \\ GALE A. NORTON, Secretary}

\section{U.S. GEOLOGICAL SURVEY \\ CHARLES G. GROAT, Director}

Any use of trade, product, or firm names in this publication is for descriptive purposes only and does not imply endorsement by the U.S. Government.

Reston, Virginia 2001

For sale by the U.S. Geological Survey, Information Services

Box 25286, Federal Center

Denver, CO 80225

\section{Library of Congress Cataloging-in-Publication Data}

Scott, Kevin M., 1935-

Catastrophic debris flows transformed from landslides in volcanic terrains: mobility, hazard assessment and mitigation strategies / by Kevin M. Scott...[et al.].

p. cm. - (U.S. Geological Survey professional paper; 1630)

Includes bibliographical references and index.

1. Debris avalanches. 2. Lahars. 3. Catastrophes (Geology). I. Scott, Kevin M., 1935II. Series

QE75.P9 no. 1630

[QE599.A2]

557.3 s-dc21

[551.3'07] 


\section{CONTENTS}

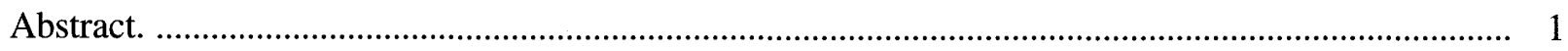

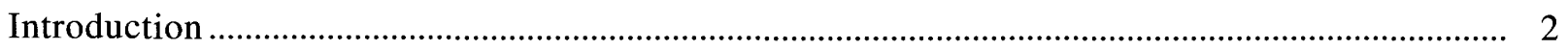

Sediment terminology-size and texture .................................................................... 4

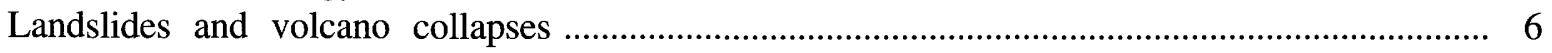

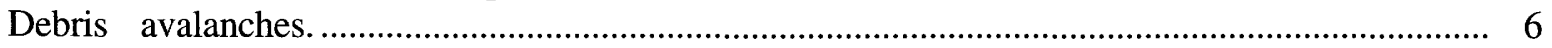

Debris flows ................................................................................................................ 7

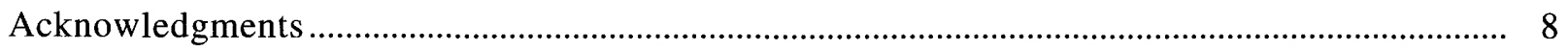

"La avalancha" in the Río Páez, Colombia-an archetypal seismogenic debris flow in

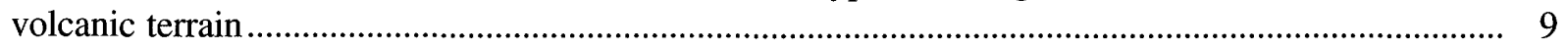

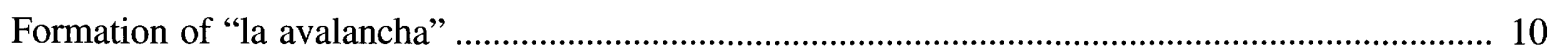

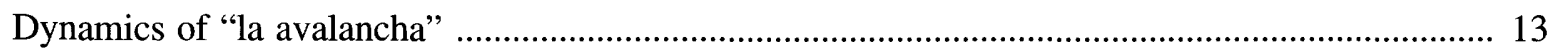

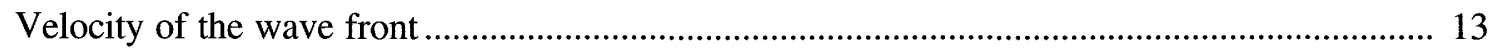

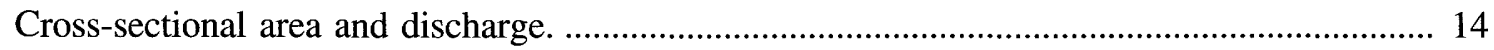

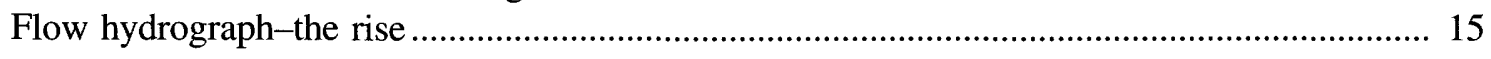

Flow hydrograph-the recession ............................................................................... 16

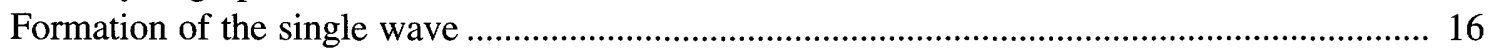

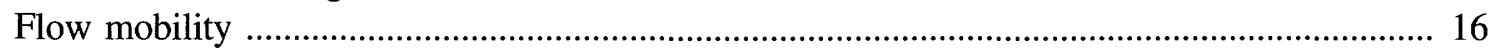

Other debris flows transformed from landslides in volcanic terrains ............................................ 16

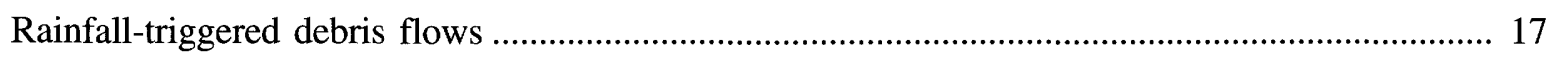

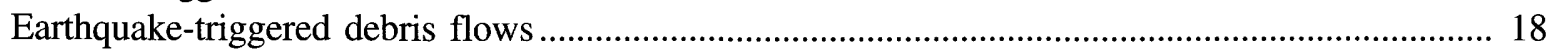

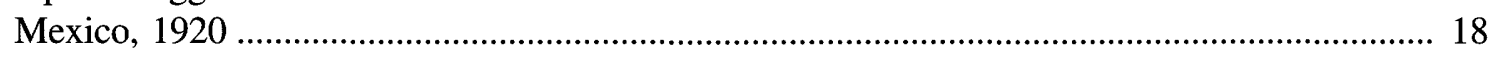

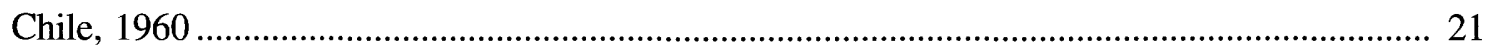

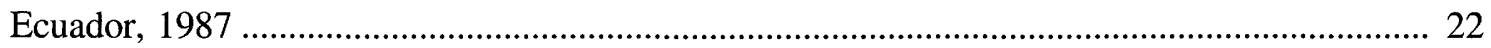

Debris flows from landslides and volcano collapses-triggering mechanisms ................................ 23

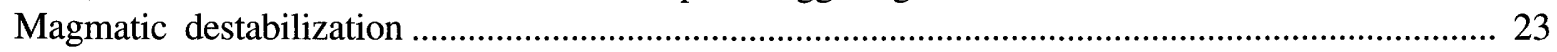

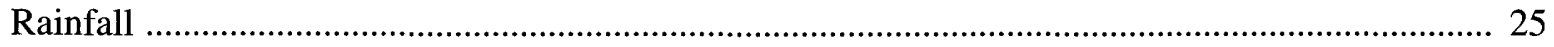

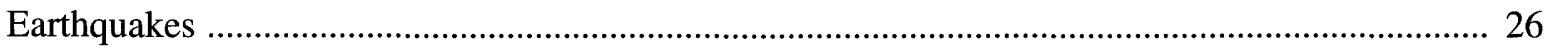

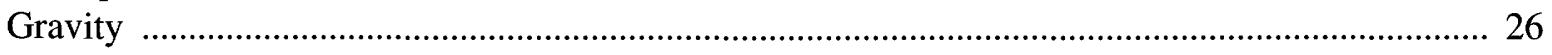

Hydrovolcanic activity (phreatic and phreatomagmatic) ......................................................... 27

Triggering mechanisms related to possibility of pre-event warning. ........................................... 27

Recognition of volcanic debris avalanches and cohesive debris flows (lahars) from deposits .............. 28

Longitudinal transformations and textural changes ................................................................. 28

Interpreting flows and their behavior from their deposits .................................................... 30

Examples from Mount Rainier ...................................................................................... 33

Examples from New Zealand .................................................................................. 34

Debris flows from landslides and volcano collapses-flow mobility ........................................... 34

Debris flows from landslides and volcano collapses-extrapolating case histories ....................... 37

Forensic documentation of flow pathways-Past events and future predictions .......................... 40

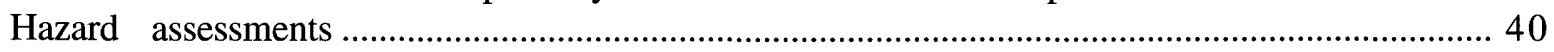

Risk analysis_Example of Mount Rainier ........................................................................ 41 


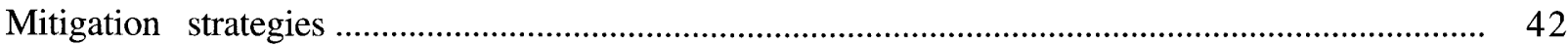

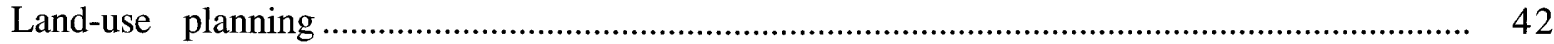

Instrumental event warnings to lowland residents in volcanic terrains ................................ 44

Educating residents of flow hazard zones to recognize the possible initiation or the actual approach of a debris flow ..................................................................................... 45

Recognition of seismic shock as a possible flow trigger ................................................... 45

Recognition of the acoustic signal of an approaching flow ................................................. 45

Education for Self Warning and Evacuation (ESWEV) .................................................. 47

Engineering measures integrating response to volcanic and hydrologic hazards ................. 49

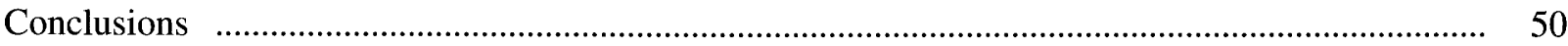

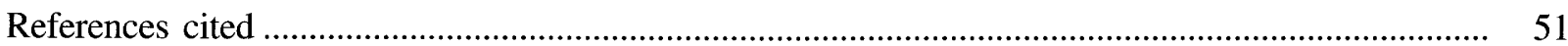

\section{FIGURES}

1. Diagram illustrating origin of textural subpopulations of debris flow deposits ................... 3

2. Photograph of debris avalanche in the Río Teno, Chile, showing clast of incoherent, lightercolored material deforming and mixing with matrix.

3. Index map showing route of debris flow triggered by the Páez earthquake of June 6, 1994 and flow cross sections illustrating growth and decay of peak discharge

4-10. Photographs showing:

4. Site of Irlanda looking northwest, showing near-synchroneity and coalescence of flows

5. Site of Tóez looking southeast.

6. Impact forces of debris flows illustrated by margin of "la avalancha" where 1-2 m of flow inundated animal barn of stone masonry

7. Margin of "la avalancha" looking downstream where it inundated the only remaining street

8. Head scarp of individual failure.

9. Hillside of Río Páez valley upstream of Irlanda showing coalescence of approximately synchronous small debris flows and debris avalanches into a larger single flow

10. Downslope deposits of flow in figure 9 showing intact masses (outlined) of soil and rock $0.7-1.0 \mathrm{~m}$ in diameter

11. Diagram showing schematic hydrographs of evolving flow wave beginning from upstream of the epicenter near Dublín through downstream communities of Irlanda, Tóez, and Belalcázar

12. Photograph showing view looking upstream (from right bank) at superelevated flow of "la avalancha" rounding bend in Río Páez

13. Map showing area of epicenter of the earthquake of January 3, 1920, and route of the seismogenic flow triggered by it.

14. Photograph of hillslopes upstream of Barranca Grande, following earthquake of January 3, 1920

15. Diagram showing stages in formation of a cohesive debris flow or lahar, where the failed mass consists of similar amounts of hard, coherent rock and weak, readily disaggregated material 
16. Photograph of view downstream in the White River valley showing mounded surface of lateral facies of the Osceola Mudflow at Huckleberry Creek, $35 \mathrm{~km}$ downstream of source

17. Aerial photograph of mounded surface of lateral deposits of the Río Teno debris avalanche

18. Longitudinal profiles of large, long-runout cohesive debris flows transformed or derived from slope failures and debris avalanches

19. Volcanic flow hazards at Mount Rainier, Washington, showing the main population centers and downstream inundation areas for the three case histories described in the text

20. Version of ESWEV message posted at campgrounds and trailheads in Mount Rainier National Park, Washington

\section{TABLES}

1. Examples of landslides and debris avalanches, mainly seismogenic, that have produced long-runout cohesive debris flows

2. Velocities of flow fronts and peak-flow velocities of seismogenic debris flows discussed in text

3. Cohesive debris flows of Holocene age beginning as flank and sector collapses on Mount Rainier and Mount Baker

4. Debris avalanches (post-A.D. 1850) from Mount Rainier and Mount Baker ...

5. Intermegaclast texture and mound density of a debris avalanche in the Río Teno, Chile, and the Osceola Mudflow

6. Mobility of volcanic debris avalanches expressed as $H / L$ values and evolution of $H / L$ values proposed to limit their extent.

7. Sources of incoherent material and fine sediment contributing to the formation of cohesive debris flows

8. Historic seismogenic debris flows in the Western Hemisphere and times of arrival of flow fronts following earthquakes at the sites of most casualties

9. Reports of noise and ground shaking associated with the approach of large debris flows

\section{CONVERSION FACTORS}

\begin{tabular}{rll} 
Multiply & By & To obtain \\
\hline millimeters $(\mathrm{mm})$ & 0.03937 & inches (in.) \\
centimeters $(\mathrm{cm})$ & 0.3937 & inches (in.) \\
meters $(\mathrm{m})$ & 3.281 & feet $(\mathrm{ft})$ \\
kilometers $(\mathrm{km})$ & 0.6214 & miles $(\mathrm{mi})$ \\
square kilometers $\left(\mathrm{km}^{2}\right)$ & 0.3861 & square miles $\left(\mathrm{mi}^{2}\right)$ \\
cubic kilometers $\left(\mathrm{km}^{3}\right)$ & 4.168 & cubic miles $\left(\mathrm{mi}^{3}\right)$ \\
meters per second $(\mathrm{m} / \mathrm{s})$ & 3.281 & feet per second $(\mathrm{ft} / \mathrm{s})$ \\
meters per second $(\mathrm{m} / \mathrm{s})$ & 2.237 & miles per hour $(\mathrm{mi} / \mathrm{h})$ \\
kilometers per minute $(\mathrm{km} / \mathrm{min})$ & 37.28 & miles per hour $(\mathrm{mi} / \mathrm{h})$ \\
cubic meters per second $\left(\mathrm{m}^{3} / \mathrm{s}\right)$ & 35.31 & cubic feet per second $\left(\mathrm{m}^{3} / \mathrm{s}\right)$ \\
\hline
\end{tabular}




\title{
Catastrophic Debris Flows Transformed from Landslides in Volcanic Terrains: Mobility, Hazard Assessment, and Mitigation Strategies
}

\author{
By Kevin M. Scott ${ }^{1}$, José Luis Macías² ${ }^{2}$ José Antonio Naranjo ${ }^{3}$, Sergio Rodríguez ${ }^{4}$, and John P. McGeehin ${ }^{1}$
}

\section{ABSTRACT}

Communities in lowlands near volcanoes are vulnerable to significant volcanic flow hazards in addition to those associated directly with eruptions. The largest such risk is from debris flows beginning as volcanic landslides, with the potential to travel over 100 kilometers. Stratovolcanic edifices commonly are hydrothermal aquifers composed of unstable, altered rock forming steep slopes at high altitudes, and the terrain surrounding them is commonly mantled by readily mobilized, weathered airfall and ashflow deposits. We propose that volcano hazard assessments integrate the potential for unanticipated debris flows with, at active volcanoes, the greater but more predictable potential of magmatically triggered flows. This proposal reinforces the already powerful arguments for minimizing populations in potential flow pathways below both active and selected inactive volcanoes. It also addresses the potential for volcano flank collapse to occur with instability early in a magmatic episode, as well as the "false-alarm

\footnotetext{
${ }^{\mathbf{1}}$ U.S. Geological Survey, ${ }^{2}$ Instituto de Geofísica, Universidad Nacional Autónoma de México, ${ }^{3}$ Servicio Nacional de Geología y Minería, Chile, ${ }^{\mathbf{4}}$ Instituto de Geología, Universidad Nacional Autónoma de México
}

problem"-the difficulty in evacuating the potential paths of these large mobile flows.

Debris flows that transform from volcanic landslides, characterized by cohesive (muddy) deposits, create risk comparable to that of their syneruptive counterparts of snow and ice-melt origin, which yield noncohesive (granular) deposits, because: (1) Volcano collapses and the failures of airfall- and ashflow-mantled slopes commonly yield highly mobile debris flows as well as debris avalanches with limited runout potential. Runout potential of debris flows may increase several fold as their volumes enlarge beyond volcanoes through bulking (entrainment) of sediment. Through this mechanism, the runouts of even relatively small collapses at Cascade Range volcanoes, in the range of 0.1 to 0.2 cubic kilometers, can extend to populated lowlands. (2) Collapse is caused by a variety of triggers: tectonic and volcanic earthquakes, gravitational failure, hydrovolcanism, and precipitation, as well as magmatic activity and eruptions. (3) Risk of collapse begins with initial magmatic activity and increases as intrusion proceeds.

An archetypal debris flow from volcanic terrain occurred in Colombia with a tectonic earthquake (M 6.4) in 1994. The Río Páez conveyed a catastrophic wave of debris flow over 
100 kilometers, coalesced from multiple slides of surficial material weakened both by weathering and by hydrothermal alteration in a large stratovolcano. Similar seismogenic flows occurred in Mexico in 1920 (M 6.5), Chile in 1960 (M 9.2), and Ecuador in 1987 (M 6.1 and 6.9). Velocities of wave fronts in two examples were 60 to 90 $\mathrm{km} / \mathrm{hr}$ (17-25 meters per second) over the initial 30 kilometers.

Volcano flank and sector collapses may produce untransformed debris avalanches, as occurred initially at Mount St. Helens in 1980. However, at least as common is direct transformation of the failed mass to a debris flow. At two other volcanoes in the Cascade RangeMount Rainier and Mount Baker-rapid transformation and high mobility were typical of most of at least 15 Holocene flows. This danger exists downstream from many stratovolcanoes worldwide; the population at risk is near 150,000 and increasing at Mount Rainier.

The first step in preventing future catastrophes is documenting past flows. Deposits of some debris flows, however, can be mistaken for those of less-mobile debris avalanches on the basis of mounds formed by buoyed megaclasts. Megaclasts may record only the proximal phase of a debris flow that began as a debris avalanche. Runout may have extended much farther, and thus future flow mobility may be underestimated. Processes and behaviors of megaclast-bearing paleoflows are best inferred from the intermegaclast matrix.

Mitigation strategy can respond to volcanic flows regardless of type and trigger by:

(1) Avoidance: Limit settlement in flow pathways to numbers that can be evacuated after event warnings (flow is occurring). (2) Instrumental event-warning systems: Rapid recognition of the seismic signal of a collapse and/or the acoustic signal of a moving debris flow. (3) Education for Self Warning and Evacuation (ESWEV) is advice to residents in flow pathways near volcanoes to seek high ground after any seismic shock or prolonged rumbling noise. (4) Engineering measures: (a) With inexorable population increases, and in areas already with high population densities, any new engineering works for flood control also can be designed to impound volcanic flows. (b) Advance planning at volcanoes like Mount Rainier can facilitate rapid construction of lahar diversion and impoundment structures when magmatic activity is detected and the risk of collapse escalates.

\section{INTRODUCTION}

Volcanic debris flows (lahars) form when snow and ice are melted by volcanic heat, water is released from a crater lake or a natural dam formed by a volcanic flow, or rainfall runoff erodes recent volcanic deposits. These hazards are well known (Neall, 1976 and 1996; Major and Newhall, 1989). We summarize the origin and behavior of a second type of volcanic debris flows, which transform directly from landslides on volcanoes and in the terrain surrounding volcanoes (fig. 1). The risks of these flows are poorly known, although comparable to the risks posed by the first category. The need for awareness of this second type of risk extends from the villagers in remote Andean valleys to the planning and emergency response staffs of agencies in the areas around Cascade Range volcanoes. We describe long-term mitigation strategies from micro to macro in scale, including networks of Acoustic Flow Monitors (AFM's) that can operate continuously in some high-risk areas.

Two recent disasters in Colombia illustrate the two flow types. Catastrophic debris flows occurred in the areas below nearly identical active stratovolcanoes, both over $5,000 \mathrm{~m}$ in altitude and $200 \mathrm{~km}$ apart on the crest of the Cordillera Central. First, on November 13, 1985, during a relatively small eruption of Volcán Nevado del Ruiz, pyroclastic flows melted snow and ice to form meltwater surges that eroded volcaniclastic sediment to form debris flows, a series of which killed 21,000 people in the city of Armero and another 2,000 elsewhere (Pierson and others, 1990; Voight, 1996). Then, on June 6, 1994, a tectonic earthquake triggered landslides on and near Volcán Nevado del Huila which coalesced to form a flow that killed as many as 1,000 people along the Río Páez.

We initially describe the second flow and its poorly known analogs. Then, because the key to preventing future disasters is knowing past 


\section{Large Volcanic Debris Flows}

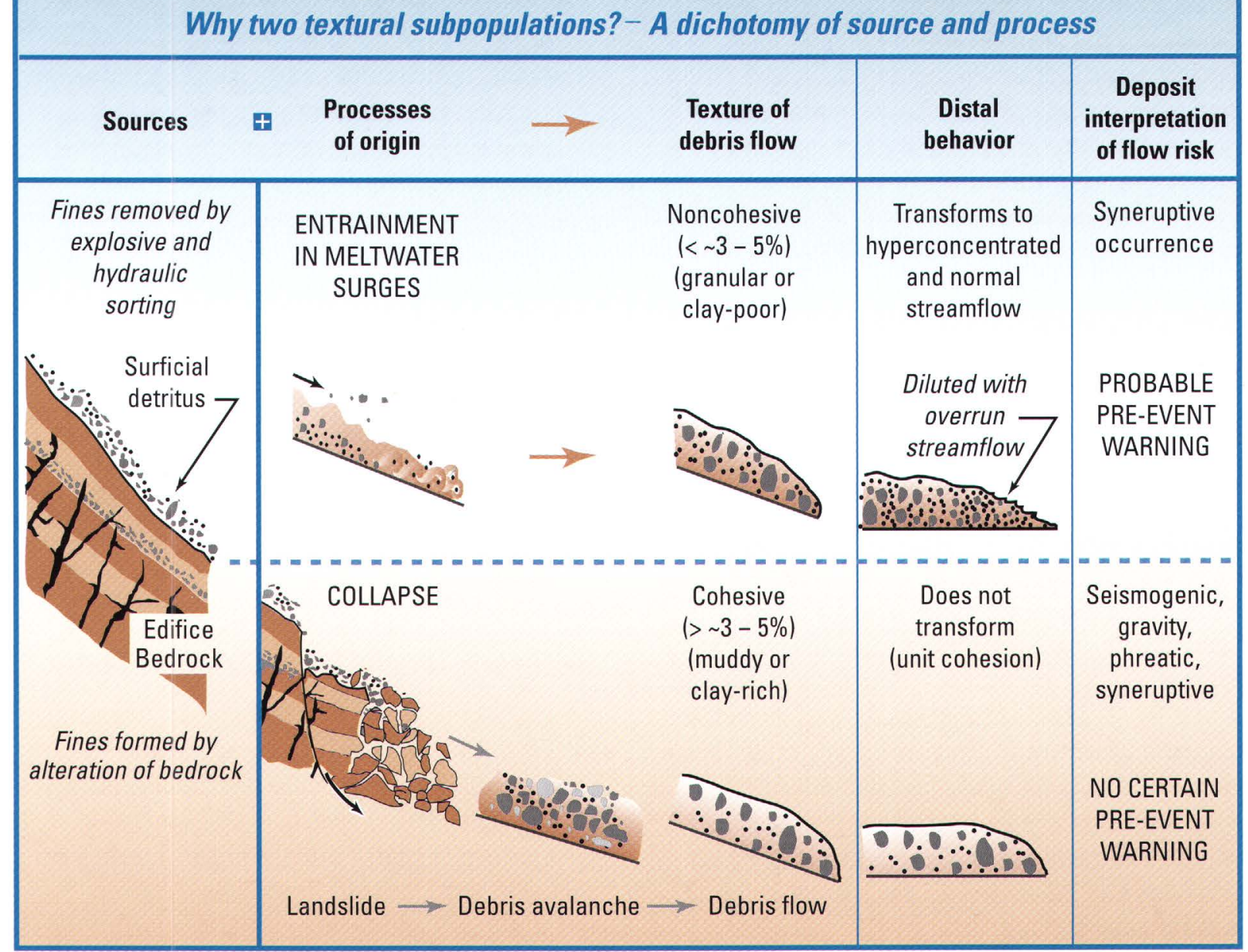

Figure 1. Diagram illustrating origin of cohesive and noncohesive textural subpopulations of debris flow deposits.

events, we describe how to recognize similar flows from paleohydrologic and sedimentologic evidence. We also address the commonly underestimated runout potential of volcanic debris avalanches and cohesive debris flows that begin as volcano collapses. Finally, because mitigation in populated valleys must consider all the flow hazards, we discuss issues of hazard assessment and mitigation strategy that apply to all large debris flows regardless of their origin or trigger. Mitigation will focus both on volcanoes and on the areas surrounding them, for large river systems are the conduits of seismogenic flows that can originate from the circum-volcano watersheds mantled by failure-prone volcanic deposits. We base mitigation strategies on prehistoric case histories, and on historic flows in the Western Hemisphere causing over 49,000 deaths. As one example, we conclude that most of these fatalities could have been prevented with the approach we describe as ESWEV (Education for Self Warning and Evacuation).

The flows that devastated Armero and other cities and towns below Nevado del Ruiz were noncohesive or granular debris flows, characterized by a sandy deposit matrix and commonly originating by volcanic melting of snow and ice, as did those flows. Because noncohesive flows generally occur with an eruption, they will be preceded by events that will warn of an impending eruption. Eruptions are preceded by magmatic activity that is revealed by accompany- 
ing earthquakes, geodetic changes, or changes in the rate or composition of gas emission. As concluded by Voight (1988, 1990, and 1996), with response to the clear precursory signals at Nevado del Ruiz, Armero could have yielded no victims but, owing to cumulative human error and the difficulty in evacuating large populations, tragedy ensued.

The catastrophic seismogenic flow in the Río Páez downstream from Nevado del Huila was the amalgamation of many small flows produced by nearly synchronous slope failures. It was a cohesive or muddy debris flow, distinguished by a muddy deposit matrix and commonly having a landslide origin (Scott and others, 1995) - the more unpredictable of the two flow types. Cohesive debris flows begin with slope failures, and failure on volcanoes is expectable with the destabilization caused by magmatic intrusion. Risk of collapse begins with the start of magmatic activity, possibly before eruption impends and evacuations are ordered. Failure may also be caused by tectonic earthquakes as well as simple gravitational collapse, hydrovolcanic activity, and intense precipitation-triggers without the precursory signals that commonly precede eruptions and most noncohesive flows. Ground vibrations and noise may be the only warning of an approaching flow.

Cohesive debris flows are commonly the final stage of transformation from a landslide of weak or readily disaggregated material to a debris avalanche and finally to a debris flow. The material weakness can result from endogenous hydrothermal activity in a volcanic edifice, where risk is from large single failures, or from exogenous weathering of flow and airfall deposits, with risk of the coalescence of many small failures into large flow waves. The flow in the Río Páez involved materials from both sources.

With our focus on material properties, this discussion may seem to neglect the important role of water in flow transformations. However, the simplification needed in order to assess hazards represented by past events and at large scales makes this necessary. Material properties of potential source materials are observable and assessable; water content may be variable and temporary. Material properties are preserved and can be interpreted in flow deposits; water content is not preserved. The water content necessary for flow transformation from landslide to debris flow occurs frequently in volcanic terrains. Stratovolcanoes have hydrothermal systems and function as aquifers; surficial deposits of steeplands in volcanic zones - many at high altitude, in the tropics, or both-are frequently wet. Both volcanoes and the steeplands of volcanic zones may extend to altitudes of permanent snow and ice in the tropics and elsewhere.

We emphasize that no conclusion of this report: (1) detracts from the vital importance of monitoring volcanoes to detect magmatic activity precursory to eruptions; (2) suggests that such activity may not be detected; or (3) questions any dynamical explanation for the mobility of landslide runouts (one estimate is of at least 20 such proposals).

\section{Sediment Terminology-Size and Texture}

Volcanological size terminology defines ash ( $<2 \mathrm{~mm}$ ), lapilli $(2-64 \mathrm{~mm})$ and blocks $(>64 \mathrm{~mm})$. The sedimentological terminology we use here defines clay $(<0.004 \mathrm{~mm})$, silt (0.004-0.0625 mm), sand $(0.0625-2 \mathrm{~mm})$, granules (2-4 mm), pebbles (4-64 mm), cobbles $(64-256 \mathrm{~mm})$, and boulders $(>256 \mathrm{~mm})$. Mud is silt plus clay; gravel is $>2 \mathrm{~mm}$. Clay refers to clay-size material or to clay minerals.

Debris flows and their deposits are bimodal, characterized by coarse particles (pebbles to cobbles or boulders) dispersed or "floating" in a finer-grained matrix, separated by a critical diameter about $2 \mathrm{~mm}$. Coarse particles are rarely in contact in the matrix of sand, silt, and clay. Cohesive debris flows have significant silt plus clay; hence their common name, mudflows. The size range and the sorting of particles are diagnostically large (examples in Vallance and Scott, 1997), second only to values for glacial till. A large literature treats the textural discrimination of tills and debris flows (for example, Landim and Frakes, 1968).

Much textural terminology for debris avalanches and debris flows is not compatible. The terminology applied in New Zealand, however, can for our purposes unify the descrip- 
tions of both flow types, in part because researchers there have long seen the continuum of flow processes that begin with volcanic landslides (for example, Neall, 1979). A debris avalanche, by definition a coarse, granular flow, contains large clasts (fragmental particles) described as megaclasts (or megablocks). In deposits, the topographic expressions of the megaclasts are mounds (also-hummocks, cerrillos, montículos, or mudflow hills). We will here consider the material finer than and between the megaclasts as intermegaclast matrix. In the case of a debris avalanche transforming to a debris flow, this intermegaclast matrix develops a pronounced bimodal texture - a dispersed or coarse phase in a finer matrix phase, with both phases identical to those of a debris flow as described above. The distinction of an intermegaclast matrix therefore requires an arbitrary size boundary to define this second level of matrix by identifying the clasts- that is, the megaclasts- that are larger than those typical of debris flow. This boundary is usefully achieved by defining megaclasts as $>1.0 \mathrm{~m}$ in intermediate diameter (Palmer and others, 1991). In a typical volcanic debris avalanche, some megaclasts are soft, incoherent, altered rock in the process of disaggregating and contributing mainly to matrix, as shown in figure 2. Other megaclasts are hard, coherent rock in the process of fracturing to smaller pieces in the intermegaclast matrix (in a debris avalanche). A domain in a debris avalanche or debris flow is a region of a deposit over which a coherent megaclast has shattered and become dispersed yet throughout which the pieces can still be seen as parts of an earlier whole (Gaylord and others, 1993). Shattered megaclasts may also remain loosely intact like a three-dimensional jigsaw puzzle (Shreve, 1968), a structure seen widely in debris avalanche deposits (Ui, 1983).

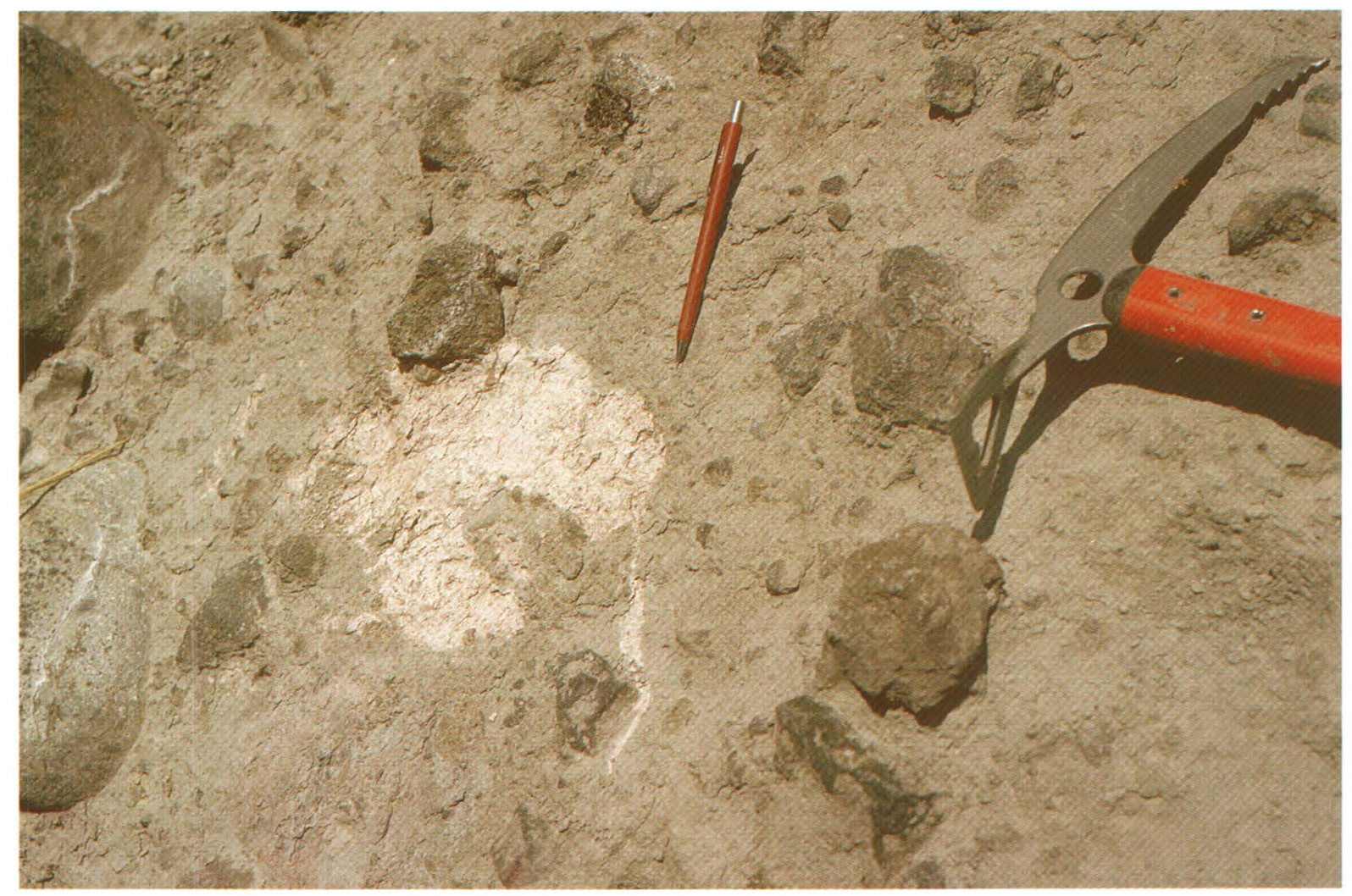

Figure 2. Clast of incoherent, lighter-colored material deforming and mixing with matrix. Note angular clasts (black) from the failed edifice (Volcán Planchón) and rounded porphyritic clasts (gray, left of pencil and at lower left of photo) entrained during flow. Debris avalanche in the Río Teno, Chile. 
A volcanic debris avalanche thus consists of three size ranges, each of which may contain a modal fraction of the total distribution(1) megaclasts $>1.0 \mathrm{~m}$; (2) clasts $<1.0 \mathrm{~m}$ to $2.0 \mathrm{~mm}$; and (3) matrix $<2.0 \mathrm{~mm}$. For our purposes, the latter two size ranges comprise the intermegaclast matrix. In the derivative cohesive debris flow, many incoherent megaclasts have become matrix, and many coherent megaclasts have shattered into the two modes of debris flow, clasts commonly $<1.0 \mathrm{~m}$ and matrix $<2.0 \mathrm{~mm}$. Megaclasts may remain dispersed in the debris flow, becoming rare over distance of travel as they either disaggregate or are stranded to form mounds.

Mistaking a cohesive debris flow for a debris avalanche can thus occur if a mounded surface is the criterion for the latter. If a deposit previously described as a volcanic debris avalanche has an intermegaclast matrix with the characteristics of a debris flow, and if the megaclasts are dispersed (their interaction did not affect flow mechanics), the deposit records a debris flow, and not the grain flow, wet or dry, of a debris avalanche.

\section{Landslides and Volcano Collapses}

Engineering geologists include as landslides all types of gravity-induced mass movements, including rock and debris avalanches and debris flows (Varnes, 1978; Cruden and Varnes; 1996). At volcanoes the term landslide is commonly used for slope movements with shear and displacement in a relatively narrow zone. The largest landslides from volcanoes-slides to engineers-are called sector or edifice collapses, failures in response to destabilization by magma intrusion or associated hydrovolcanism. A typical sector collapse has a volume of at least $1 \mathrm{~km}^{3}$ (Crandell, 1989). Failure may depressurize a magmatic system and thereby trigger explosive activity. Volcanic landslides much smaller than a sector collapse may also yield farreaching debris flows, and we use the term flank collapse (Scott and others, 1998) for these failures. Most of the initiating landslides of the dated cohesive debris flows from volcanoes in the Cascade Range cited herein are so described. Sector collapses can be distinguished from flank collapses by describing the former as large enough to involve the volcano summit, and the latter as smaller failures only involving the flank. Some seismologists (for example, Moran 1997, p. 120) discuss both sector and flank collapses as we do flank collapses. The smaller size of a flank collapse indicates that there need be no repose time before another flank collapse occurs, and hence they can be treated as random events. Edifice reconstruction generally must occur before a second sector collapse. Cohesive debris flows that began with a sector collapse were the 1980 debris flow in the North Fork Toutle River at Mount St. Helens (Scott, 1988a) and the synchronous Osceola Mudflow and Paradise Lahar at Mount Rainier (Vallance and Scott, 1997). Other flows in the data set from Mount Rainier and Mount Baker began as flank collapses.

\section{Debris Avalanches}

A debris avalanche is a sudden, very rapid flow of an incoherent, unsorted mixture of rock and soil in response to gravity (Schuster and Crandell, 1984). It is a common middle stage in the transformation of a cohesive debris flow from a landslide or rockslide. Debris avalanches may be restricted to grain flows or granular flows, in which flow mechanics are governed by particle interactions involving friction and collision (cf., Pierson and Costa, 1987; Iverson, 1997). Debris flows, in contrast, owe much of their behavior to excess pore-water pressure and a pore fluid that is viscous and contains fine sediment (Iverson, 1997). The volcanic debris avalanches described in a large volume of literature include (1) debris avalanches sensu stricto that were mainly grain flows, as described by Glicken (1998), (2) debris avalanches that were grain flows for an interval of proximal flow before transforming to debris flows, and (3) debris avalanches recorded by deposits that are entirely those of debris flows. The latter may have been grain flows for a brief interval unrecorded by deposits. Case histories indicate that the distinction between debris avalanche and debris flow is far from black or white-continuous gradations exist in the percentage of megaclasts, in fine sediment content, and in mobility. 
Recognition of the importance of volcanic debris avalanches owes much to the case histories compiled by Siebert (1984), Inokuchi (1989), and Crandell (1989). The nonvolcanic or alpine counterparts of these flows (Li, 1983; Costa, 1984) are similarly well known, are commonly described as rock avalanches, and are more likely to represent debris avalanches sensu stricto. This difference in behavior largely relates to differences in properties of the failed materials. Stratovolcanoes yield slope failures of soft, hydrothermally altered and clay-rich material that may quickly mobilize to form a matrix-rich slurry that, if saturated, can flow without inherent limitation. In attempting to generalize, we may say that the failures of hard, wet rock in alpine settings tend to produce rock avalanches, and the failures of soft, wet rock in volcanic settings tend to produce debris flows.

\section{Debris Flows}

The deposit-based distinction between cohesive and noncohesive debris flows evolved with the post-1980 (Mount St. Helens) renaissance of interest in volcanic flows. Size analyses from deposits of more than 50 flow with known modern or paleohydrologic behaviors at Mount St. Helens (Scott, 1988a) and Mount Rainier (Scott and others, 1995) revealed that the deposits of flows that had remained debris flows to their distal ends contained distinctly more fine sediment than the deposits of flows that had transformed by dilution and loss of yield strength to hyperconcentrated streamflow, the process described by Pierson and Scott (1985). This observation (fig. 1) differentiates many flows that began as sector or flank collapses (cohesive flows) from many that began as eruption-induced meltwater surges or lake breakouts that entrained volcaniclastic detritus (noncohesive flows). The limiting percentage by weight of clay in the total deposit is about 3 percent, and in the matrix $(<2 \mathrm{~mm})$ is about 5 percent (clay/sand + silt + clay; Vallance and Scott, 1997, fig. 2). This percentage expectedly will vary with factors such as clay mineral species and the degree of clay aggregation. Muddy and granular (Scott, 1997) and relatively clay-rich and clay-poor (Vallance and Scott, 1997) are synonyms for the cohesive- noncohesive distinction in deposits for those concerned with any engineering implications of the terms as applied to the flows. The term cohesive debris flow here refers only to a flow yielding cohesive deposits, as defined above.

The two textural subpopulations fundamentally reflect the two main source materials for debris flows at volcanoes (fig. 1). The fine sediment in cohesive flows of landslide origin reflects the hydrothermal alteration of edifice bedrock to clay (as well as by weathering). The paucity of fine sediment in noncohesive flows reflects the small quantities of fines typical of most surficial volcaniclastic detritus that is entrained in surges of melt- or lake water; the fines were removed during the selective sorting by earlier surficial processes. It may also reflect entrainment of deposits without a lot of primary fine sediment such as those of some pyroclastic flows or tephra, and it may reflect distal transformations of flows without much fine sediment, such as some block-and-ash flows and other kinds of pyroclastic flows.

The textures of most, generally smaller, precipitation-induced and glacial-outburst flows, excluded from our discussion by scale considerations, reflect the vagaries of source materials, but they are commonly noncohesive. Textural exceptions are the fine-grained, so-called rainfall lahars produced from large volumes of fine ash and ash-cloud deposits, such as the many examples east of Popocatépetl in Mexico (Siebe and others, 1996, p. 399). Especially at tropical volcanoes such as those in the Philippines and Indonesia, large rainfall lahars can be extreme hazards that continue for years after eruptions (see Pierson and others, 1992; Newhall and Punongbayan, 1996; and Neall, 1996). For hazard assessment and mitigation, however, a crucial issue for large rainfall-generated flows is their generally syneruptive or posteruptive onset, so that there is a degree of predictability and thus the potential for pre-event warnings. An exception is a rainfall-triggered flank collapse, an example of which produced a large, muddy lahar in 1998 at inactive Volcán Casita in Nicaragua (Sheridan and others, 1998; Scott, 2000). There, although fine sediment came from failed material that was partially hydrothermally altered, most 
was derived by bulking of fine-grained soil and ash beyond the edifice.

Truly catastrophic noncohesive debris flows can result from bulking of the surges released from lakes either in craters (see Neall, 1996) or dammed by volcanic landslides and avalanches. For these cases, future risks at volcanoes may be apparent from present topography or previous occurrence. For example, a sequence of deposits of huge debris flows from prehistoric breakouts of the avalanche-dammed Spirit Lake at Mount St. Helens (the lake was dammed prehistorically and again in 1980) has unique sedimentological characteristics (Scott, 1988b). When a flow creates or enlarges a natural dam that subsequently fails, as opposed to immediately displacing water, a period of time before failure generally will permit evacuation and some degree of mitigation (examples in Costa and Schuster, 1991).

This textural dichotomy based on matrix thus is a useful tool in reconstructing the debris flow history of a volcano. It can be the basis for probabilistic risk assessment based on stratigraphic analysis of volcanic debris flows. The differences in matrix texture are easily observed in the field and are readily confirmed by laboratory analysis. The role of cohesive forces in affecting flow mechanics is not inferred; any interpretations of the role of fine sediment on the physical processes of debris flows should be based on flow-mechanics research (for example, Iverson, 1997; Major and others, 1997).

A volcanic debris flow is a lahar (Vallance, 2000), following worldwide usage and the tradition of Crandell (1971) in the Cascade Range. Some flows, and parts of others described herein, did not originate directly from the edifices of volcanoes so for uniformity we describe all flows here only as debris flows. The public knows debris flows as mudflows or mudslides, but these terms are now discarded in scientific usage because mud is rarely the dominant constituent, and it may be a very minor part of noncohesive debris flows. The term mudflow is retained if part of a formal name, as in Osceola Mudflow.

\section{ACKNOWLEDGMENTS}

We thank the many colleagues cited herein for discussions on the outcrops of volcanic terrains around the Pacific Rim. We owe much to the heritage of our association with Richard J. Janda who, in the years following Mount St. Helens, emphasized the importance of assessing eruption hazards as well as the hazards resulting from volcanoes as unstable landforms consisting of weak, saturated rock at high altitudes.

The difficulties in generating public response to debris flow hazards are, firstly, the extreme distances these mobile flows can travel to populated lowlands, and secondly, the nature of the hazard at volcanoes as less predictable than the hazards that accompany eruptions-with the potential for flank collapse to be the initial hazard in an intrusive or eruptive episode, to occur with magmatic activity but without an eruption, or to occur with no warning at all. We acknowledge the staffs of the Department of Emergency Services and the Department of Planning and Land Services in Pierce County, Washington; Pierce County contains the populated pathways that will be most at risk from future lahars at Mount Rainier. In 1991, William M. Lokey, Director of Emergency Services, was instrumental in integrating a magnitude-and-frequency analysis of flow hazards (Scott and others, 1992 and 1995), based in significant part on the work of Crandell (1971), into that County's Comprehensive Plan as mandated by the 1990 Growth Management Act of the State of Washington. Lokey and Planner Mark T. Truckey coordinated defenses against challenges, including a lawsuit by a municipal agency. The land-use restrictions of the Comprehensive Plan remain in effect, restricting the population growth and location of critical facilities (schools, hospitals, and so forth) within the lahar pathways of Rainier. The present Director of Emergency Services in Pierce County, Stephen C. Bailey, continues this tradition of effective public and governmental enterprise with the consortium of over 30 local, State, and Federal agencies known as the Mount Rainier Working Group. The Working Group develops mitigation strategies for volcanic and hydrologic 
hazards from this dangerous volcano, including the network of Acoustic Flow Monitors we discuss herein and, in 2001, the placement of over 200 road signs that will guide people within lahar pathways to high ground.

\section{"LA AVALANCHA" IN THE RÍO PÁEZ, COLOMBIA-AN ARCHETYPE SEISMOGENIC DEBRIS FLOW IN VOLCANIC TERRAIN}

Seismogenic debris flows emerged clearly as a significant volcano hazard with the occurrence of the catastrophic flow in southwestern Colombia remembered as "la avalancha," triggered by an earthquake on June 6, 1994 (Casadevall and others, 1994; Red Seismológica Nacional de Colombia, 1994). Its conduit was the Río Páez (fig. 3), the river system that drains all of the massive active stratovolcano, Nevado del Huila, elevation 5,364 m (main summit or Pico Central; Pulgarín and Macías, 1998) on the crest of the Cordillera Central. The Río Páez flows $69.8 \mathrm{~km}$ south from Dublín, site of the earthquake epicenter $10 \mathrm{~km}$ southwest of the volcano summit, through mountains with local relief of more than $1,000 \mathrm{~m}$ and slopes typically more than 30 degrees. The only level sites for communities are the terraces formed by deposits of debris avalanches and debris flows. The river then leaves the Cordillera Central, turning $40.8 \mathrm{~km}$ east to join the northward regional drainage of the Río Magdalena.

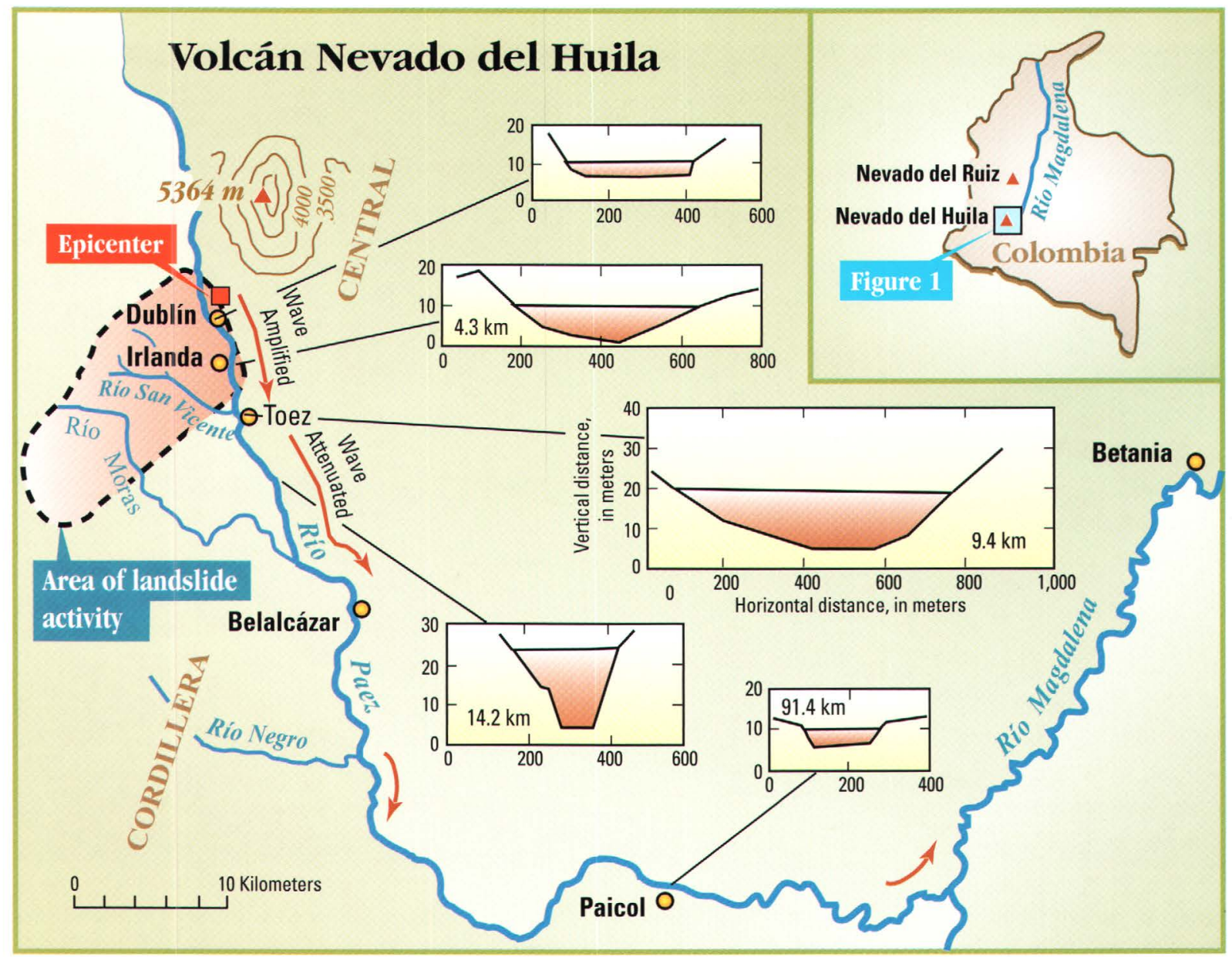

Figure 3. Index map showing route of debris flow triggered by the Páez earthquake of June 6, 1994. Flow cross sections illustrating growth and decay of peak discharge were determined by field estimates and scaling from ground and air photos. Area of intense landslide activity after Martínez and others (1995). 
Within minutes, a catastrophic debris flow wave inundated successive communities along the Río Páez (figs. 3-5). By June 10, 589 deaths were attributed to the flow, although an official count from all causes was lower (United Nations Department of Humanitarian Affairs, 1994). Estimates include total casualties of approximately 1,100 (Avila and others, 1995). Many fatalities were also caused by the earthquake and primary landslides; deaths from each cause are unknown, but most were caused by "la avalancha" and its tributary flows.

Devastation was profound at Irlanda (fig. 4), population 300, $4.3 \mathrm{~km}$ downstream from Dublín; and at Tóez (fig. 5), population 1,000, $9.4 \mathrm{~km}$ downstream (populations estimated by $\mathrm{El}$ Tiempo, June 8, 1994). Both communities were described as "buried," and half the population of Tóez was initially reported killed, but later estimates were lower. Tóez was first leveled by earthquake, then within minutes most of the town was buried by debris flow (figs. 6 and 7).

Unless otherwise cited, quotations in the following sections are translations of eyewitness accounts from the newspapers El Tiempo and $E l$ Espectador in Bogotá.

\section{Formation of "La Avalancha"}

Approximately 50 percent of $>100 \mathrm{~km}^{2}$ of upland terrain failed as shallow slides (Avila and others, 1995). Saturated by recent rainfall, failures mobilized rapidly into debris flows during the 30 second duration of the quake

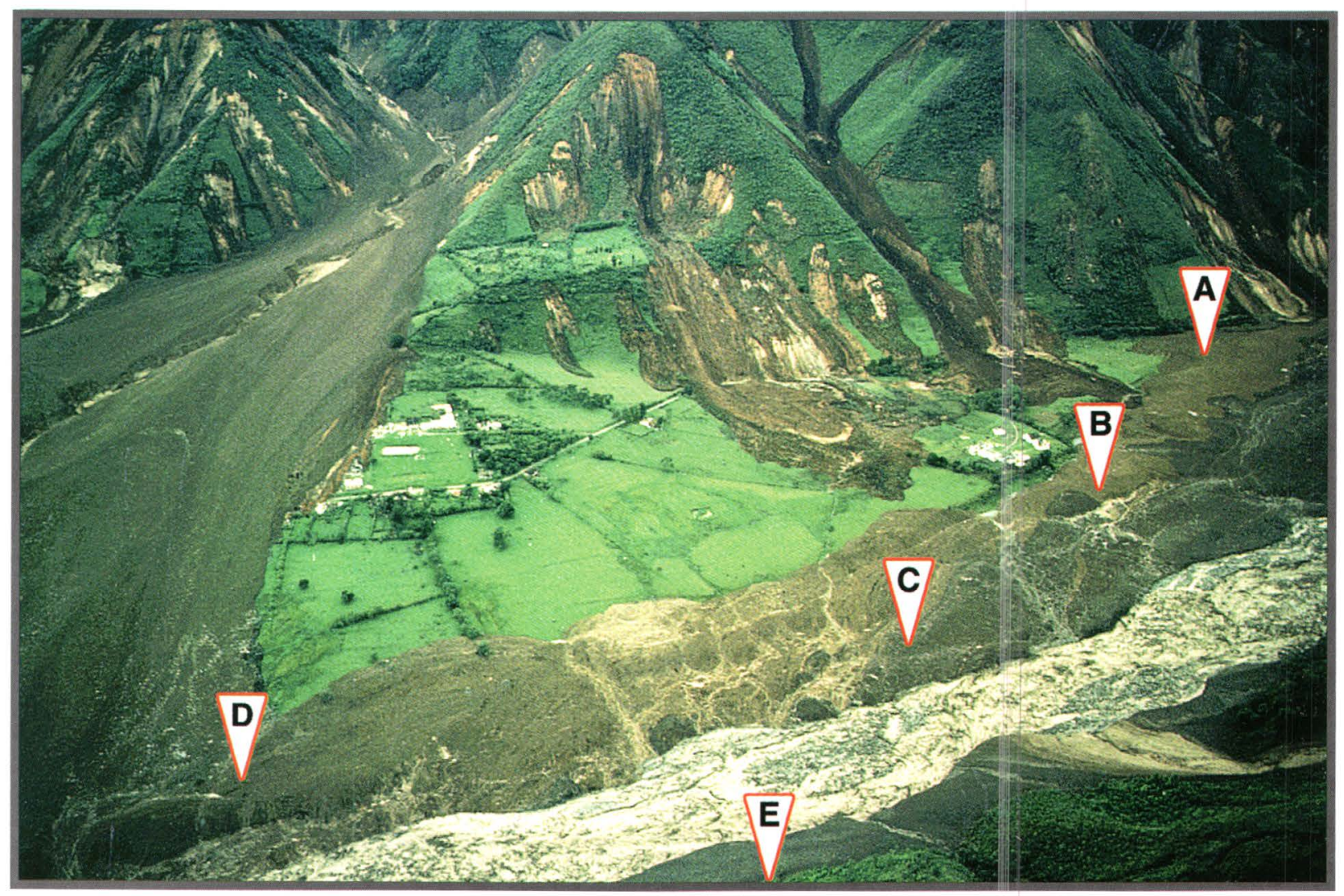

Figure 4. Site of Irlanda looking northwest, showing near-synchroneity and coalescence of flows. Río Páez flows from right to left in the foreground. Note (A) right bank runup of brown flow originating on opposite, left side of channel; (B) peak flow of momentarily later channelized black flow from upstream; (C) runback of part of brown flow over black flow, which had now passed by; (D) brown flow overruning large tributary flow which also overran the channelized and momentarily previous black flow; (E) evidence of only channelized black flow on left bank. Photograph by T.J. Casadevall. 
(Martínez and others, 1995). Slides originated from the edifice of Nevado del Huila, but most came from surrounding terrain (fig. 3). More than 3,000 discrete slope failures, 3-7 $\mathrm{m}$ in depth, were mapped on aerial photos (Avila and others, 1995); typical slides involved soil, colluvium, and altered and weathered bedrock. Much of the failed material, clay-rich and reddish to ochre in color, flowed as slurries containing progressively disaggregating megaclasts to the nearest channel (figs. 8-10), where they overran and mixed with streamflow. Factors adding to the instability of the regolith were the probable presence of tephra layers and the long-term destruction of the tropical highland vegetation by livestock (both illustrated in fig. 8).

Bedrock contributing to failures (Avila and others, 1995) comprised hydrothermally altered lavas of the edifice of Nevado del Huila, weathered granitoid rock, other hydrothermally altered and fractured intrusive igneous rocks, and other volcaniclastic, sedimentary, and metasedimentary rocks. The deposit of a large volcanic debris avalanche and debris flow ( $>10 \mathrm{~km}^{3}$; Pulgarín and Macías, 1998; Pulgarín, 2000) forms a terrace, without mounds in this area, about $100 \mathrm{~m}$ above the Río Páez (fig. 5); deposits of younger volcanic debris flows form the lower, inhabited terraces (figs. 4 and 5).

Near the epicenter, where most of the terrain failed, black soil and rock were mixed with yellow and white material, an unknown proportion of which consists of tephra. Downstream survivors commented on the striking color contrast of the rust-colored flows they saw on slopes (fig. 4) and the black channelized flow that came from upstream (fig. 4 at lower right; fig. 5). This color contrast contributed to early controversy over the origin of the channelized flow. Was it related to collapse of Nevado del Huila, its

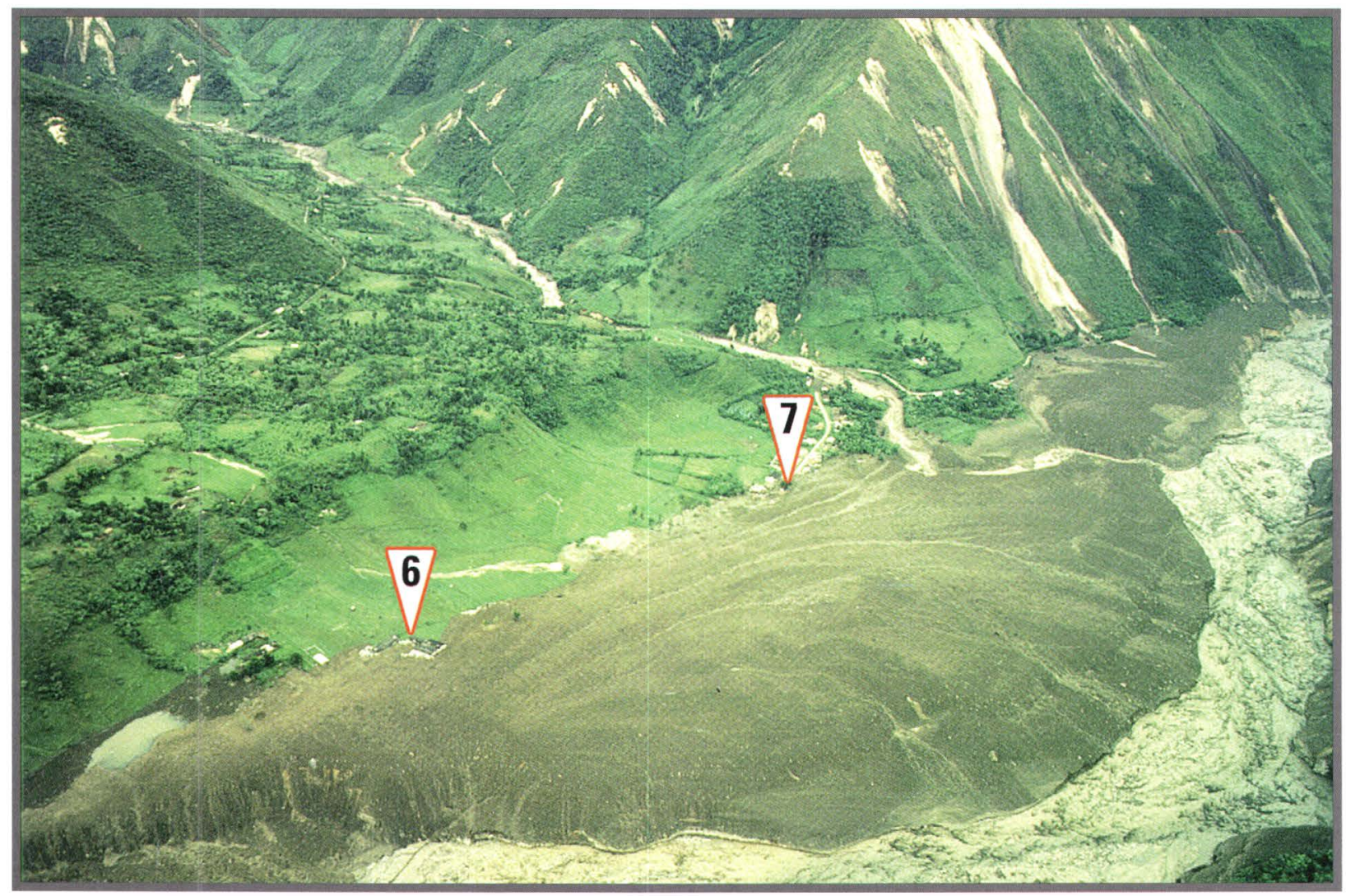

Figure 5. Site of Tóez looking southeast. Río Páez flows from left to right. Pointers show locations of figures 6 and 7. Prominant high terrace (with trees) is formed by deposits (without mounds) of a debris avalanche runout from a collapse of Nevado del Huila. Photograph by T.J. Casadevall. 


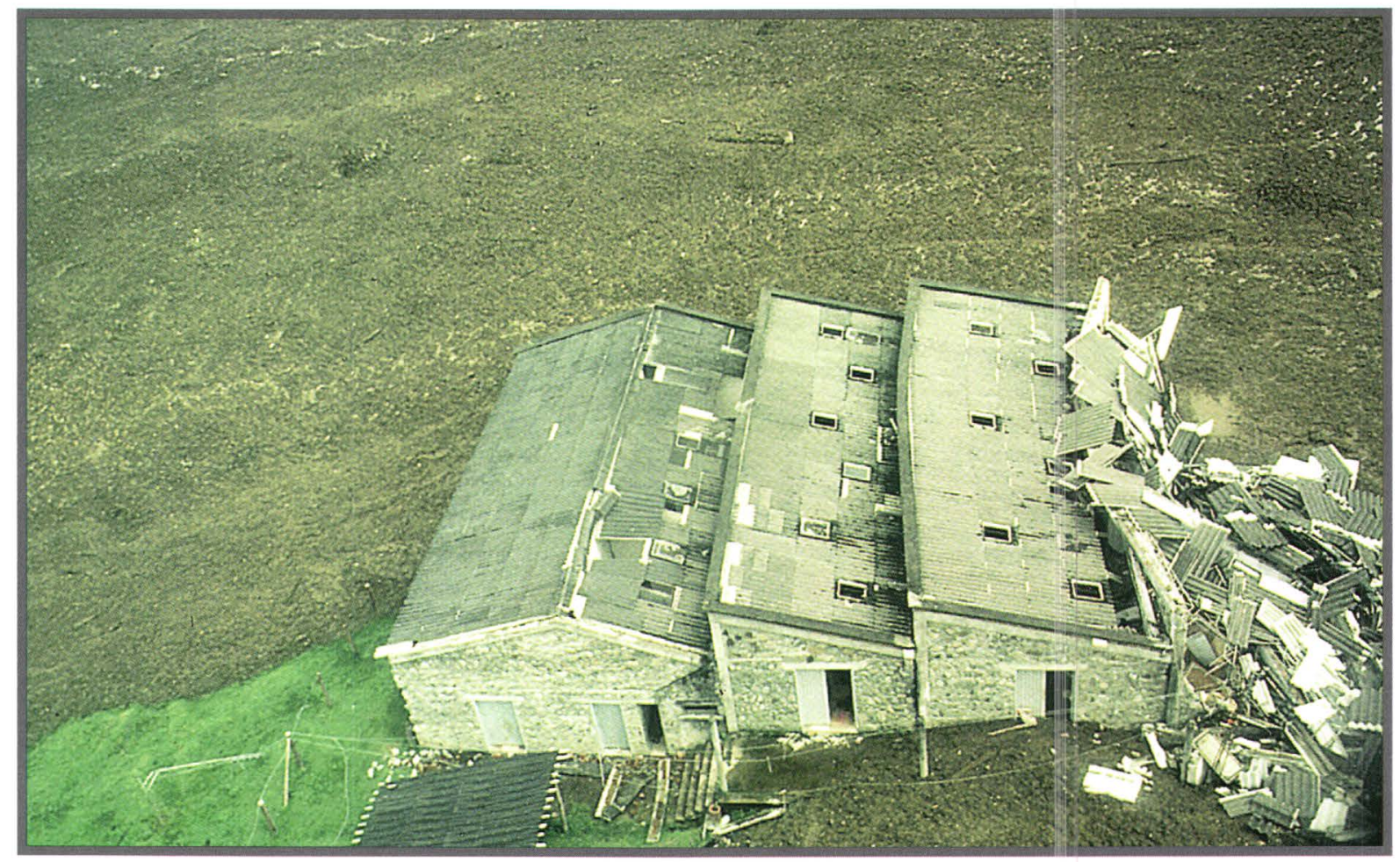

Figure 6. Impact forces of debris flows illustrated by margin of "la avalancha" where 1-2 $\mathrm{m}$ of flow inundated animal barn of stone masonry. Location shown by left pointer in figure 5. Photo by T.J. Casadevall.

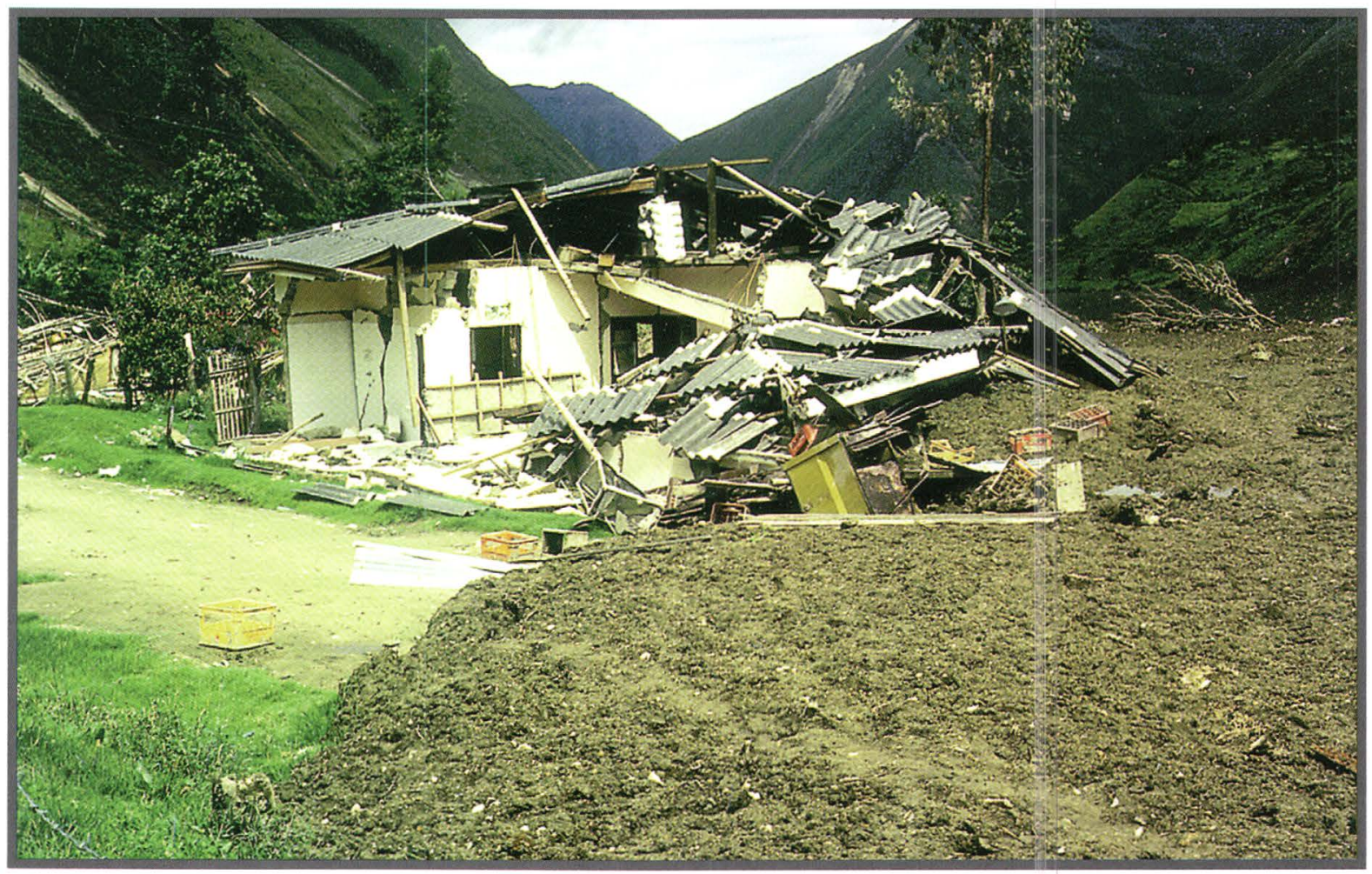

Figure 7. Margin of "la avalancha" looking downstream where it inundated the only remaining street. Deposit thickness is $1.2 \mathrm{~m}$. Location shown by right pointer in figure 5 . 
13.4-km² icecap, or to volcanic activity? Later study showed that the earthquake was tectonic with its epicenter at the base of the volcano (Martínez and others, 1995), that the icecap was not involved, and that, although slides occurred on the volcano, most originated in the surrounding terrain.

The downstream arrival times of the wave front establish that flow in the Río Páez began near and upstream from the epicenter nearly synchronously with the quake. Between Dublín and Irlanda and between Irlanda and Tóez the flow wave grew progressively in response to tributary contributions. Although insurgent revolutionary activity prevented access to Dublín, aerial observations and videotape of the flow cross-section near the site show it to have been less than half of the maximum downstream dimension (fig. 3).

\section{Dynamics of "La Avalancha"}

\section{Velocity of the wave front}

Reports of arrival time of the flow front at Belalcázar, $30.3 \mathrm{~km}$ downstream and the largest community hit by the flow, are variable. Estimates of the time interval between earthquake and flow arrival range from 10 minutes, when the flow was "felt while still $5 \mathrm{~km}$ away" (reported in El Tiempo, June 8, p. 14A), to 20 minutes ( $E l$ Tiempo, June 8, p. 14A), to 30 minutes ( $E l$ Tiempo, June 10). A time of 20 to 30 minutes

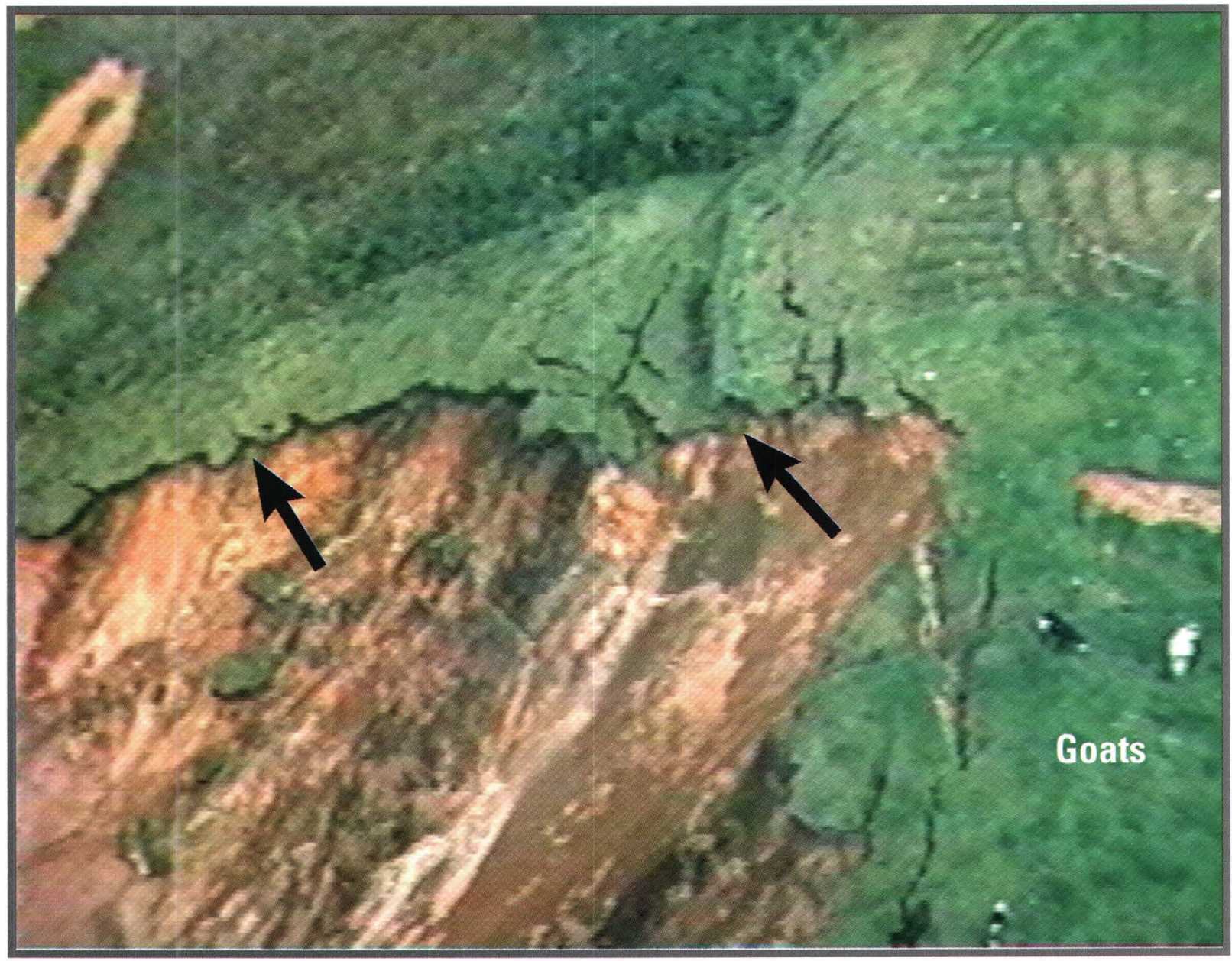

Figure 8. Head scarp of individual failure. Note initial failure as blocks. Note white layer of probable tephra (arrows), about $10 \mathrm{~cm}$ in thickness, beneath black, organic-rich surface layer, approximately $0.3 \mathrm{~m}$ in thickness, and overlying rust-colored, altered and weathered bedrock. From INGEOMINAS (1995b). 
yields a velocity of the wave front from the epicenter of between 60 and $90 \mathrm{~km} / \mathrm{hr}$ (17 to 25 $\mathrm{m} / \mathrm{s}$ ). Channel slope is $0.04 \mathrm{~m} / \mathrm{m}$ between Irlanda and Tóez and decreases to less than 0.015 at the Río Negro (measured on 1:25,000 maps).

Calderón and others (1997) cite an unpublished estimate by INGEOMINAS of flow velocity between 15 and $20 \mathrm{~m} / \mathrm{s}$ over an unknown distance.

\section{Cross-sectional area and discharge}

Estimates of flow cross sections (fig. 3) are from ground photos, aerial videotape, and field notes. The following figures indicate relative changes accurately but are different from and generally less than those derived subsequently by photogrammetry (H. Cepeda, written commun.,

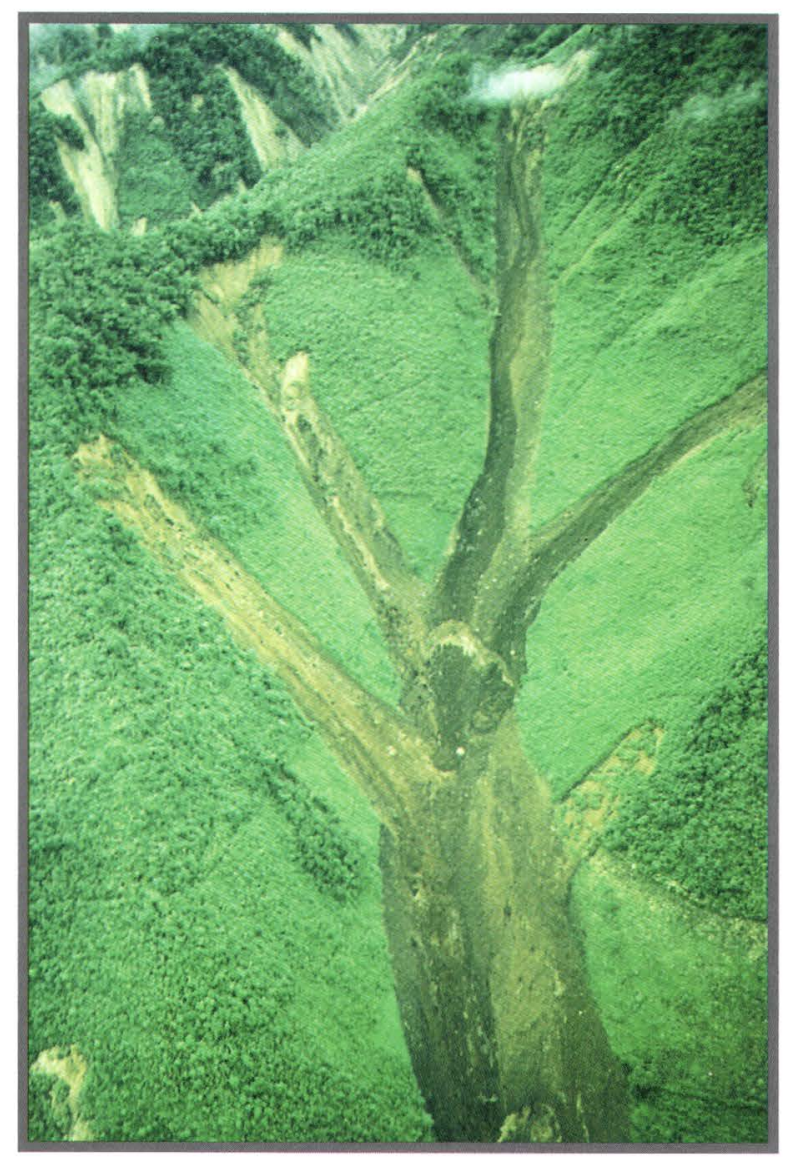

Figure 9. Coalescence of approximately synchronous small debris flows and debris avalanches into a larger single wave of debris flow. Hillside of Río Páez valley upstream of Irlanda. Photograph by R.L. Schuster.
1997). At the epicenter near Dublín, the cross section of flow was estimated at less than $3,000 \mathrm{~m}^{2}$ from aerial video. The peak flow crosssectional area increased to about $4,000 \mathrm{~m}^{2}$ at Irlanda. Initially at Irlanda, a locally derived flow crossed the channel toward the community and produced a superelevated right-bank trimline. There is a striking color contrast between this rust-colored flow of local origin and the black channelized surge that subsequently, probably in a matter of seconds, came from upstream to overrun the first flow. Figure 4 shows the channel reach where this occurred. Similar effects are responsible for some of the differences in stage levels noted above.

The maximum flow cross-sectional area was attained near Tóez, estimated at over $8,000 \mathrm{~m}^{2}$. It was augmented there by a nearly synchronous

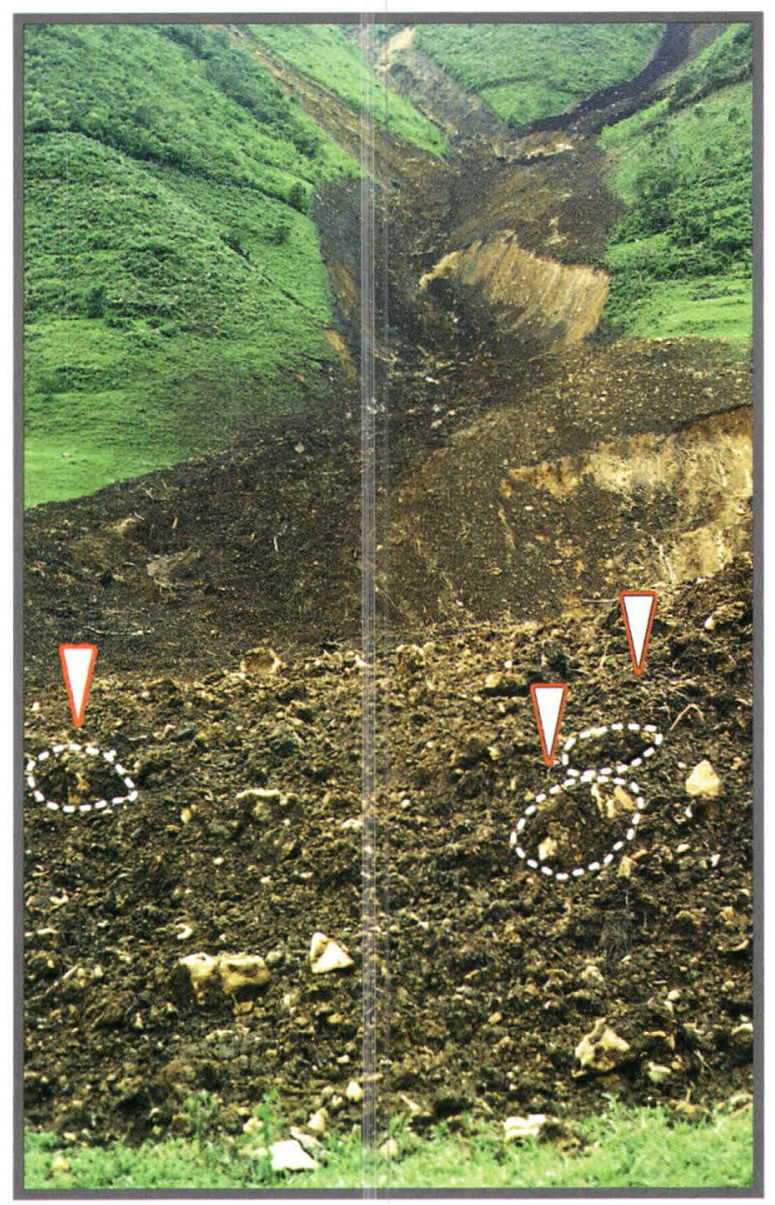

Figure 10. Downslope deposits of flow in Figure 9. Intact masses (outlined) of soil and rock are $0.7-1.0 \mathrm{~m}$ in diameter. Height of berm is $3.5 \mathrm{~m}$. 
flow from the Río San Vicente (fig. 11). The maximum depth of flow was $40 \mathrm{~m}$

(INGEOMINAS, 1995a), attained in confined reaches below Tóez. Downstream from Tóez the flow wave attenuated progressively, to an estimated cross-sectional area of $600 \mathrm{~m}^{2}$ at Paicol, $91.4 \mathrm{~km}$ from the epicenter. By that point, discharge had declined to less than $6,000 \mathrm{~m}^{3} / \mathrm{s}$ from a peak in excess of $100,000 \mathrm{~m}^{3} / \mathrm{s}$ near Tóez.

Figure 11 is a schematic portrayal of the wave formation, its growth and decline, and the time of travel of its front to the four communities.

\section{Flow hydrograph-the rise}

The sudden appearance of the "thundering" 10-12 m high front of the wave stunned the survivors of the earthquake. They had thought the noise and ground shaking caused by the flow were an aftershock. The initial rise was an almost instantaneous front, marked by "cascading trees and boulders." Thereafter, stage continued to rise rapidly as much as $30 \mathrm{~m}$ more, and the trimline of peak stage formed within several minutes of front arrival, according to observations near Belalcázar. One survivor recalled an initial flow (probably the violent front of the surge) followed, apparently shortly ("within moments"), by a second, stronger surge (probably the sustained rise). That surge then rose steadily and rapidly into buildings in backwater areas, flowing through doors and windows to engulf many victims. All structures in the direct path of the flow were crushed.

Survivor recollections are dramatic, but they reveal aspects of the flow behavior-" giant

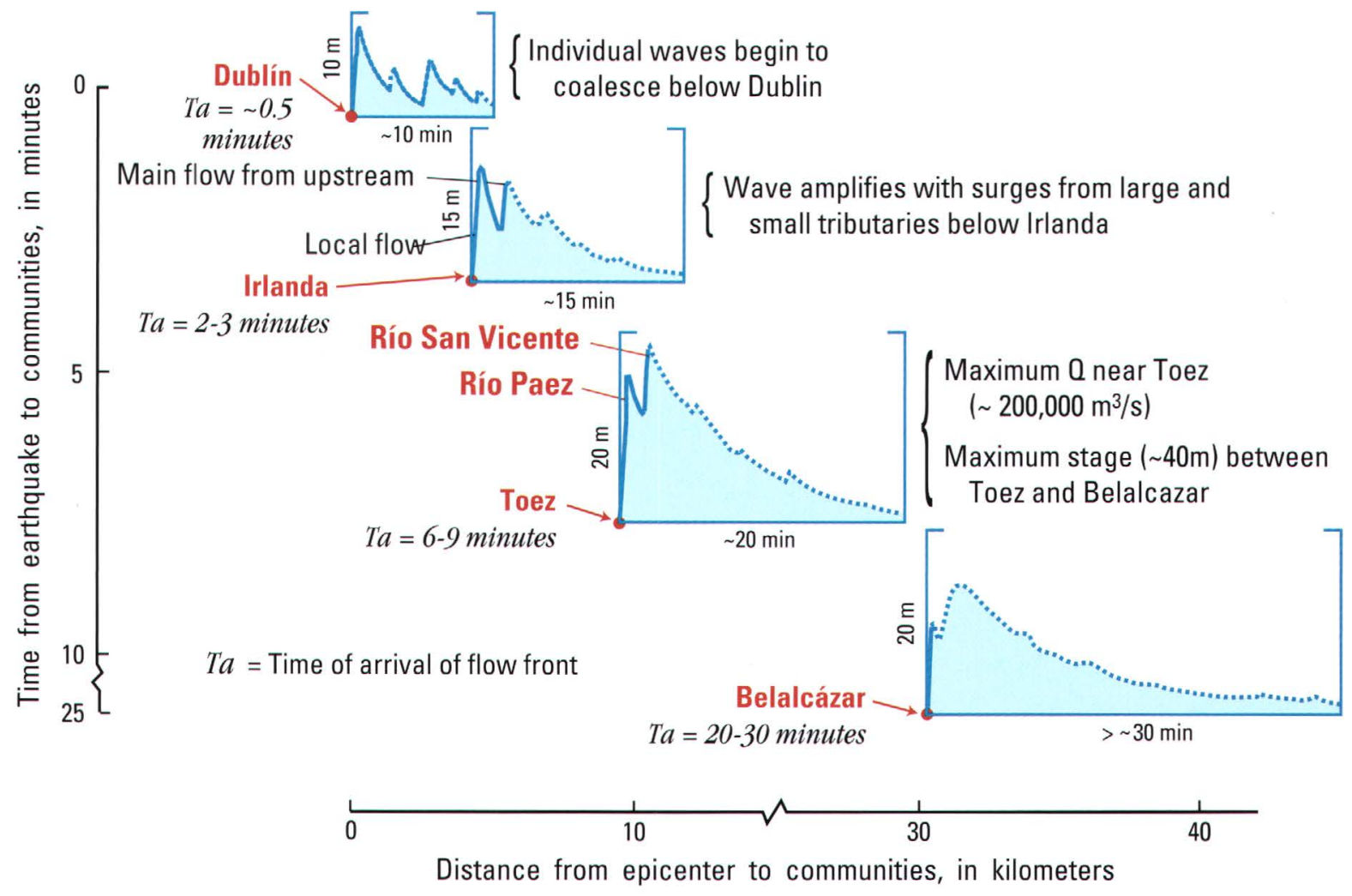

Figure 11. Schematic hydrographs showing evolution of flow wave beginning from upstream of the epicenter near Dublín through downstream communities of Irlanda, Tóez, and Belalcázar (main plot references distance from epicenter and time of flow arrival at the four communities). Flow depth, distance from epicenter, and time of arrival (Ta) after earthquake are estimated, measured, or from published accounts of eyewitnesses; hydrograph recessions are estimated from anecdotal accounts. 
waves of mud and rock," "tracks of the wave of death," "...that came on us (like a) black cloud with the force of a blast," and "obliterating all in its path" (El Espectador, June 8, and El Tiempo, June 9). "First, we heard a sound, as if the earth and mountains were roaring" (ital. added-see subsequent discussion). Then came the torrent, ripping up immense trees as if they were weeds. Within moments, it filled every corner and then passed on" (El Tiempo, June 8).

\section{Flow hydrograph-the recession}

Estimates of the duration of wave recession are variable, ranging upward from "several minutes." Summation of the evidence suggests that initial recession may have been rapid, although more gradual than the rise, followed by gradual decline over much of the next hour. The stage decline was remarkable for its smoothness, as recorded by most accounts and in the uniform coating of mud in the remains of houses and on trees. Variations in mud coatings normally reveal small oscillations in stage during the recessions of debris flows.

At two sites, the wave was recorded on videotape near its peak and shortly thereafter (INGEOMINAS, 1995b). Smooth, streaming fluid like flowing concrete is streaked with the longitudinal shear lines of a debris flow. Standing waves appear to be 3-4 $\mathrm{m}$ in amplitude, and a few megaclasts and many shredded trees are seen at the surface. Momentarily, a photographer recorded the greatly superelevated flow in an upstream bend (fig. 12).

\section{Formation of the single wave.}

"La avalancha" was the channelized amalgamation of earthquake-induced slides from the steep slopes of the Río Páez drainage (fig. 4). The huge wave and its steep front represent the integration of two effects: (1) Cannibalism of early smaller surges by a single large surge. The first flows reaching the main channel dammed and mixed with streamflow, creating many small, dilute surges that continued down the channel. One large surge grew rapidly as it overran the smaller surges in front of it because of its greater speed. (2) Inferred higher resistance to flow once the wave height rose above the level of the active channel. Once the wave height rose above the level of the active channel, the front may have been significantly slowed by high hydraulic roughness from the tropical, streamside forest (observations of "cascading trunks" at the flow front). This may have allowed some subsequent surges, also in the process of cannibalizing their smaller consorts, to catch up, and then for most to coalesce into the single huge wave. Tributary inflows to the main channel after passage of the peak were sufficiently numerous that in aggregate they smoothed and extended the recessional limb of the wave without creating large secondary surges. At Irlanda, evidence indicates that the channelized flow followed, overrode, and then raced ahead of a locally derived surge (fig. 4).

\section{Flow mobility.}

Flow deposits at Paicol, $91.4 \mathrm{~km}$ downstream, were entirely those of a debris flow. Although unconfirmed, debris flow probably extended $40.8 \mathrm{~km}$ beyond Paicol to the confluence with the Río Magdalena. The debris flow was reported by unknown sources to have reached Betania Reservoir, another $40 \mathrm{~km}$ downstream (H. Cepeda, personal commun., 1997). This summary assumes that debris flow extended at least $100 \mathrm{~km}$, but the total runout distance was probably $132 \mathrm{~km}$ and may have been as much as $170 \mathrm{~km}$ to the reservoir (elev. $500 \mathrm{~m}$ ). The $200-\mathrm{km}^{2}$ area of most intense failure was mainly at altitudes of 2,500-3,000 m, resulting in a value of $H / L$ (fall height/runout distance $)=<0.025(<2.5 / 100)$.

\section{OTHER DEBRIS FLOWS TRANSFORMED FROM LANDSLIDES OF SURFICIAL DEPOSITS IN VOLCANIC TERRAINS}

The tephra-rich surficial deposits that mantle large areas of the terrain around volcanoes, as well as the volcanic edifices themselves, are sources of hazardous debris flows. The most common triggering events are rainfall and earthquakes. The contribution of airfall deposits to the instability of volcanic terrains is indicated 
by their association, both as source materials and in stratigraphic section as planes of slippage, with more than half the landslides in large areas of Japan.

\section{Rainfall-Triggered Debris Flows}

Hydrometeorological events commonly trigger multiple, locally disastrous debris flows, described commonly as mudflows or mudslides, but these rarely have the size or the synchroneity of origin necessary to coalesce into large, longrunout flows. However, the potential for creation of catastrophic flows is illustrated by the debris flows from several small drainages $\left(<1.8 \mathrm{~km}^{2}\right)$ near Sarno, Italy, 12-18 km east and prevailingly downwind from Vesuvius, on May 5, 1998

(Pareschi and others, 1998 and 2000). More than 150 people died from these "nearly contemporaneous" flows. The failed material consisted of colluvium interbedded and mixed with a cumulative thickness of more than $6 \mathrm{~m}$ of tephra from numerous eruptions of Vesuvius and the Campi Flegrei volcanoes. Long-term urbanization and the progressive degradation of the natural vegetation were factors contributing to the 1998 disaster (Pareschi and others, 1998 and 2000). Disastrous flows of this origin are likely to recur over long historic periods, as has occurred in the vicinity of Sarno. Migale and Milone (1998) record epi-

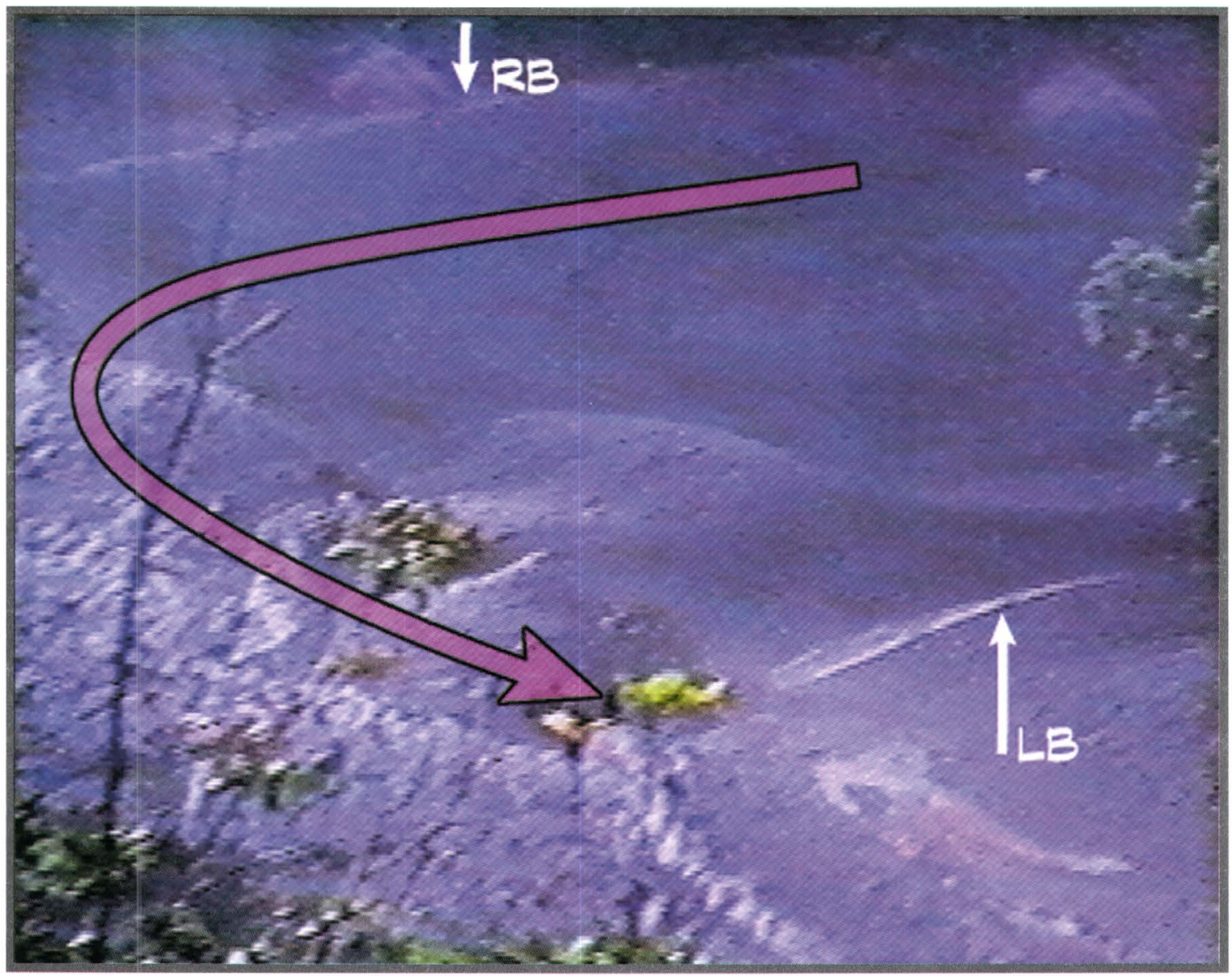

Figure 12. View looking upstream (from right bank) at superelevated flow of "la avalancha" rounding bend in Río Páez in direction of large arrow. Note markedly concave surface of flow, causing flow cross sectional area to be greatly overestimated if the flow surface is subsequently assumed to have been a straight line connecting the trimlines. Difference in altitude between left and right edges of flow (LB and RB arrows) is 12-15 m. "Waves" in flow reflect topography. Triangular shapes at top of frame are reflections in camera lens. From INGEOMINAS (1995b). 
sodes of rainfall-triggered, circum-Vesuvian debris flows: in 1640 (40 deaths); 1764 (43 deaths); 1823 (120 deaths); 1841 (120 deaths); 1910 (170 deaths); 1924 (30 deaths); and 1954 (30 deaths).

\section{Earthquake-Triggered Debris Flows}

The coalescence of multiple, seismogenic landslides into a wave of debris flow, as occurred in the Río Páez, is a process that would seem to have a high potential for recurrence. Some earthquakes in tropical but not necessarily volcanic steeplands have produced an intensity of slope failures (Pain, 1972; Garwood and others, 1979) comparable to that from the Páez earthquake, but long-runout debris flows in channels were not recognized. They may have occurred, however, but simply not been reported because of a lack of communities along river channels or of hydrologically oriented observers. Conversely, they may not have occurred because of the lack of sufficient moisture to mobilize failed material at the time of the earthquake or, more probably, the absence of unstable and easily mobilized deposits such as the surficial deposits of volcanic airfall and ashflows. The following analogs of the flow in the Río Páez emerge from literature review (table 1 ):

\section{Mexico, 1920}

On January 3, 1920, a powerful tectonic earthquake caused debris flows like those in the Río Páez in rugged highlands $30 \mathrm{~km}$ northeast of Pico de Orizaba. Pico is a major stratovolcano and the highest peak in Mexico (Carrasco-Núñez and Gómez-Tuena, 1997). The main conduit was the Río Huitzilapan (fig. 13) with headwaters draining the Las Cumbres volcanic complex (Rodríguez and Komorowski, 1997). The magnitude of the earthquake was $\sim 6.5-7.0$, based on reported intensity values (fig. 13), evaluation of those results in terms of Modified Mercalli intensities, and conversion to moment magnitude M as calibrated by Bakun and Wentworth (1997). Singh and others (1984) estimated a magnitude of 6.4. "Enormous" mudflows 40 to $65 \mathrm{~m}$ deep formed in channels as the amalgamations of many small landslides, mobilized by ground water, of ashflow- and tephra-mantled volcanic bedrock and limestone (Camacho, 1922; Flores, 1922). In a reconnaissance report, Oddone (1921) describes the failed material as "powdered and muddy material, for the most part volcanic tuff." A 1920 photograph (fig. 14) shows numerous surficial failures like those along the Río Páez. Prior to a description by Siebe and others (1993) and the trip to the area by Rodríguez and Scott in October 1996, the event was largely unrecognized, in spite of the insightful reports of Camacho and Flores (Instituto Geológico de México, 1922).

The largest destroyed town was Barranca Grande, built on a valley flat in the valley of the Río Huitzilapan $15 \mathrm{~km}$ downstream from the epicenter. Flores (1922, p. 28) reported the loss of 220 lives from a population of 300 , but Camacho (1922, p. 88) noted the downstream recovery of 600 bodies. A local resident today recalls 30 survivors among 900 villagers in 1920. The population of modern Barranca Grande is also estimated at 900 by that resident, and about half of the modern generation has settled on ground higher than the inundation of 1920.

Villagers "heard" the flow "5 minutes before it arrived" (Flores, 1922, p. 28), and most, like those near the Río Páez who felt it $5 \mathrm{~km}$ away in 1994, thought it was an aftershock ("a second earthquake"). The noise was described as " $a$ prolonged muffled thunderclap, many wagons rolling across pavement, or charging cavalry" (ital. added-see subsequent discussion). But, " $a$ few said it was not a subterranean sound but was a flow in the river (ital. added-see subsequent discussion). These few fled toward the high ground, but such was the velocity of the flow that some of these, in spite of recognizing the danger and running rapidly, simply perished" (translation of account in Flores, 1922, p. 28). Flores (1922) notes that a father, leading two small sons, found that the boys could not run fast enough, and to save himself he left them to be overrun. An important aspect of this account, discussed in our final section on event warning, is the perception by only a few individuals that the noise and ground tremor were not from an earthquake but were from a flow in the river. 
Table 1. Examples of landslides and debris avalanches, mainly seismogenic, that have produced long-runout cohesive debris flows.

\begin{tabular}{|c|c|c|c|c|c|c|}
\hline Locality & Date & Associated earthquake & Texture of debris flow & Runout distance (km) & Source rock and water & References \\
\hline $\begin{array}{l}\text { Río Páez, Colombia } \\
\text { near Nevado del Huila }\end{array}$ & $6-6-94$ & $\begin{array}{l}\text { M } 6.4 . \\
\text { Source near epicenter, } \\
10 \mathrm{~km} \text { southwest of } \\
\text { volcano. }\end{array}$ & Cohesive ( $3-12 \%$ clay) & $>100$ & $\begin{array}{l}\text { Shallow landslides of soil } \\
\text { and altered and weathered } \\
\text { rock. Ground water, } \\
\text { surface water. }\end{array}$ & $\begin{array}{l}\text { Martinez and others, } \\
\text { 1995; Avila and others } \\
\text { 1995; this report }\end{array}$ \\
\hline $\begin{array}{l}\text { Río Huitzilapan, Mexico, } \\
\text { near Pico de Orizaba }\end{array}$ & $1-3-20$ & $\begin{array}{l}\mathrm{M} \sim 6.5-7.0 \\
\text { Source near epicenter. }\end{array}$ & $\begin{array}{l}\text { Cohesive ( } 5 \% \text { clay, } \\
\text { sampled in 1996) }\end{array}$ & $>40$ & $\begin{array}{l}\text { Shallow landslides of } \\
\text { soil and altered and } \\
\text { weathered rock. Ground } \\
\text { water, surface water. }\end{array}$ & $\begin{array}{l}\text { Flores, } 1922 ; \\
\text { Camacho,1922; } \\
\text { this report }\end{array}$ \\
\hline Lake Rupanco, Chile & $5-22-60$ & $\begin{array}{l}\text { M } 9.2 \\
\text { Epicenter } 200 \mathrm{~km} \\
\text { northwest. }\end{array}$ & $\begin{array}{l}\text { Unknown, but probably } \\
\text { cohesive }\end{array}$ & 5 to lake & $\begin{array}{l}\text { Shallow landslides in } \\
\text { tephra-rich regolith. } \\
\text { Ground water from } \\
\text { "heavy"rain on 5-20. }\end{array}$ & $\begin{array}{l}\text { Wright and Mella, } \\
1963\end{array}$ \\
\hline $\begin{array}{l}\text { Río Due and Río Coca, } \\
\text { Ecuador, near } \\
\text { Reventador Volcano }\end{array}$ & $3-5-87$ & $\begin{array}{l}\text { M } 6.1 \text { and } 6.9 \\
\text { Epicenter } 25 \mathrm{~km} \text { north } \\
\text { of volcano. }\end{array}$ & $\begin{array}{l}\text { Probably cohesive; } \\
\text { described as rivers of } \\
\text { mud and rock }\end{array}$ & $>60$ & $\begin{array}{l}\text { Shallow landslides of } \\
\text { soil and altered and } \\
\text { weathered rock. Ground } \\
\text { water, surface water. }\end{array}$ & $\begin{array}{l}\text { Ishihara and Nakamura, } \\
\text { 1987; Nieto and others, } \\
\text { 1991; Schuster and } \\
\text { others, } 1996\end{array}$ \\
\hline $\begin{array}{l}\text { North Fork Toutle River, } \\
\text { drains Mount St. Helens }\end{array}$ & $5-18-80$ & $\begin{array}{l}\text { Debris avalanche } \\
\text { associated with M 5+ } \\
\text { earthquake. }\end{array}$ & $\begin{array}{l}\text { Type example of } \\
\text { cohesive debris flow } \\
\text { (>3\% clay) }\end{array}$ & $\begin{array}{l}\text { Avalanche } 29 \text {; debris } \\
\text { flow a further }>80 \\
\text { to sea level }\end{array}$ & $\begin{array}{l}\text { Altered rock from } \\
\text { edifice. Ground water, } \\
\text { snow and ice, surface } \\
\text { water. }\end{array}$ & $\begin{array}{l}\text { Voight and others, 1983; } \\
\text { Fairchild, 1985; } \\
\text { Scott, 1988a }\end{array}$ \\
\hline $\begin{array}{l}\text { Río Santa, Peru, drains } \\
\text { Nevados Huascarán }\end{array}$ & $5-31-70$ & $\begin{array}{l}\text { M } 7.75 . \\
\text { Epicenter } 130 \mathrm{~km} \text { west. }\end{array}$ & $\begin{array}{l}\text { Cohesive; matrix "soft } \\
\text { and sticky" (3-24\% silt } \\
\text { and clay) }\end{array}$ & 160 to sea level & $\begin{array}{l}\text { Fractured granitoid rock. } \\
\text { Snow and ice from } \\
\text { source area and glacier, } \\
\text { surface water. }\end{array}$ & $\begin{array}{l}\text { Plafker and Ericksen, } \\
1975\end{array}$ \\
\hline $\begin{array}{l}\text { Osceola Mudflow in } \\
\text { White River, drains } \\
\text { Mount Rainier }\end{array}$ & $\begin{array}{l}\text { Prehistoric } \\
(4,832 \pm \\
43 \text { B.P. })\end{array}$ & $\begin{array}{l}\text { Occurred with eruptive } \\
\text { activity. }\end{array}$ & $\begin{array}{l}\text { Cohesive (mean of } 7 \% \\
\text { clay in } 13 \text { samples } \\
\text { from axial facies) }\end{array}$ & $\begin{array}{l}\text { Mound-bearing facies } \\
\text { to } 70 \mathrm{~km} \text {; flow } 125 \mathrm{~km} \\
\text { to sea lavel }\end{array}$ & $\begin{array}{l}\text { Altered rock from edifice. } \\
\text { Ground water, snow } \\
\text { and ice, surface water. }\end{array}$ & $\begin{array}{l}\text { Crandell, 1971; } \\
\text { Scott and others, 1995; } \\
\text { Vallance and Scott, } 1997\end{array}$ \\
\hline
\end{tabular}

Note: Age of Osceola Mudflow is given in radiocarbon years before present as determined by Vallance and Scott (1997). 
Two elderly residents of Barranca Grande remember the actual event, and their oral history of the disaster is clearly appreciated by the modern residents. Another resident told Rodríguez that the town was hit by three successive waves, believed by modern residents to have resulted from damming and sudden release of flow. Large deep-seated slides appear to have temporarily dammed the upstream channel; a landslide described by Camacho (1922, p. 90) can be seen today to have dammed the river upstream of Patlanalá in 1920. Most slides were shallow failures (fig. 14) that mobilized to slurries transporting debris to the main channel where, just as in Colombia in 1994, the flows continued and coalesced into one or more catastrophic waves. "There is no mountain [bordering $10 \mathrm{~km}$ of the main channel in the epicentral zone] that does not show the prints and scars of slides" (Camacho, 1922, p. 90).

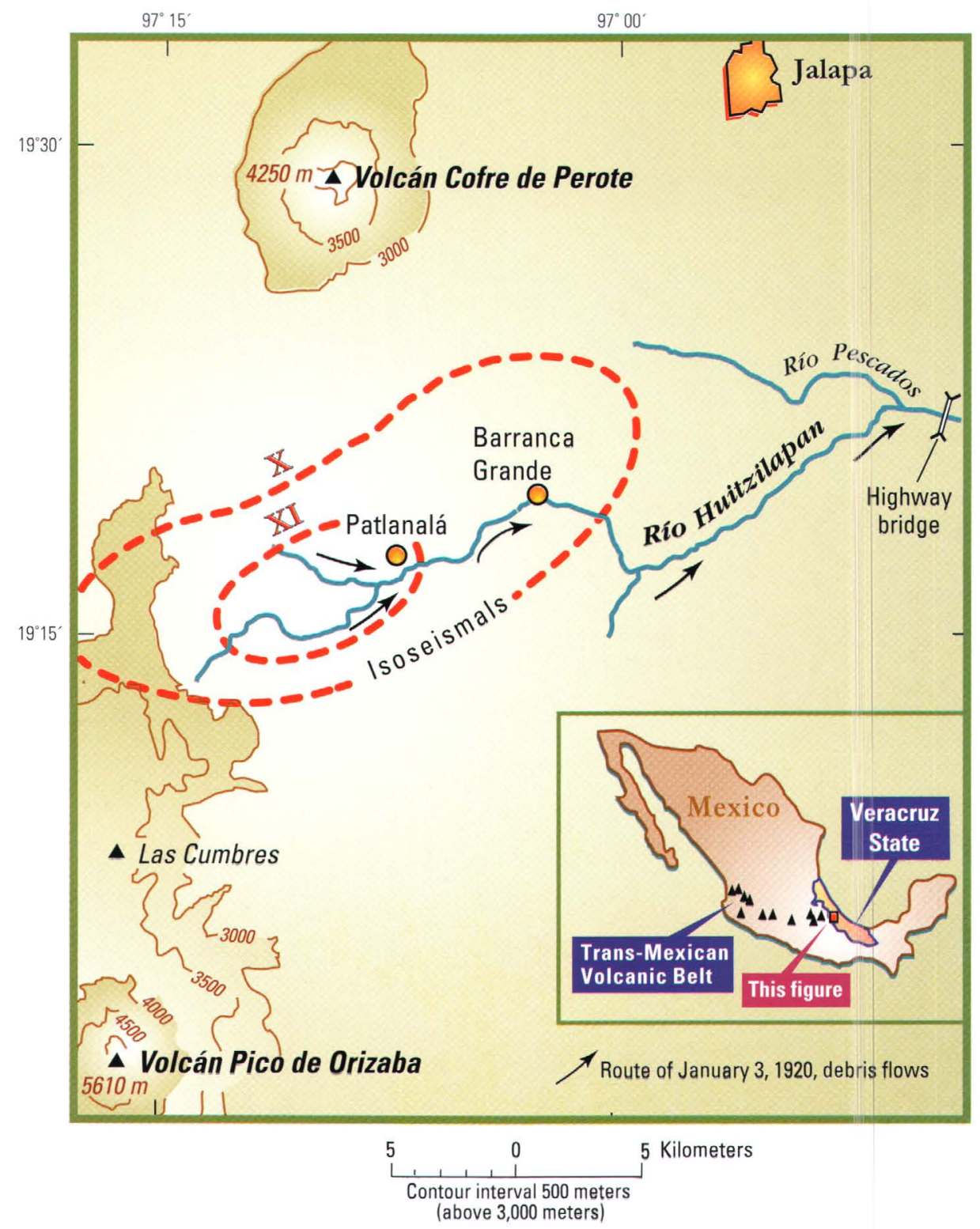

Figure 13. Map showing area of epicenter of the earthquake of January 3, 1920, and route of the seismogenic debris flows triggered by it. Isoseismals (Escala de Cancani) after Instituto Geológico de México (1922, Lam. I-B). 
In the Río Huitzilapan, superelevations of approximately $10 \mathrm{~m}$ (Camacho, 1922, p. 92) indicate velocities of in excess of about $20 \mathrm{~m} / \mathrm{s}$ (table 2). Laboratory analyses of our samples of the 1920 flow deposits at Barranca Grande indicates the texture (clay $\sim 5$ percent of matrix) of a cohesive debris flow. Similar deposits were seen in 1996 at a bridge crossing $30 \mathrm{~km}$ downstream (fig. 13) and are inferred to be correlative with the 1920 flow. The deposits of an older and larger debris flow are reported to underlie the 1920 deposits (M.F. Sheridan, personal commun., 2001).

\section{Chile, 1960}

The Chilean earthquake (M 9.2) of May 22, 1960 produced huge seismogenic debris flows in at least one area, near Lake Rupanco, $200 \mathrm{~km}$ southeast of the offshore epicenter (Wright and Mella, 1963). However, because reports concentrated on the dramatic coastal devastation by tsunamis, seismogenic debris flows in channels were almost certainly more widespread than in this small part of the total affected area. Much of the area, within the Southern Volcanic Zone of Chile, is underlain by soils weathered from fine- grained tephra with a significant content of allophane, a clay mineral with water-absorbing properties that can cause slope instability. One of us (Naranjo) notes the additional importance of bedrock jointing and fault cataclasis in the area. Lake Rupanco is surrounded by stratovolcanoes active in historic time-Puyehue, $31 \mathrm{~km}$ northeast; Osorno, $24 \mathrm{~km}$ due south, and Calbuco, $50 \mathrm{~km}$ south. At the east end of the lake, debris flows killed 125 people, including a man fleeing a debris flow on horseback (table 2): "others (victims) were enveloped in rapid-moving layers of mud, rocks, and trees that developed wherever landslides converged" (ital. added). "In some cases, whole mountainsides 5 to $8 \mathrm{~km}$ wide were suddenly completely stripped of vegetation and soil. In places this enormous mass thundered down directly into the lake... In two places..., debris avalanches converged and formed enormous mudflows, which advanced with surprising rapidity over the intervening rolling land and then finally discharged into the lake" (Wright and Mella, 1963, p. 1379, 1382-3).

Debris flows in this area were entirely contained in Lake Rupanco but, without that large impoundment (10 x $44 \mathrm{~km})$, flows would

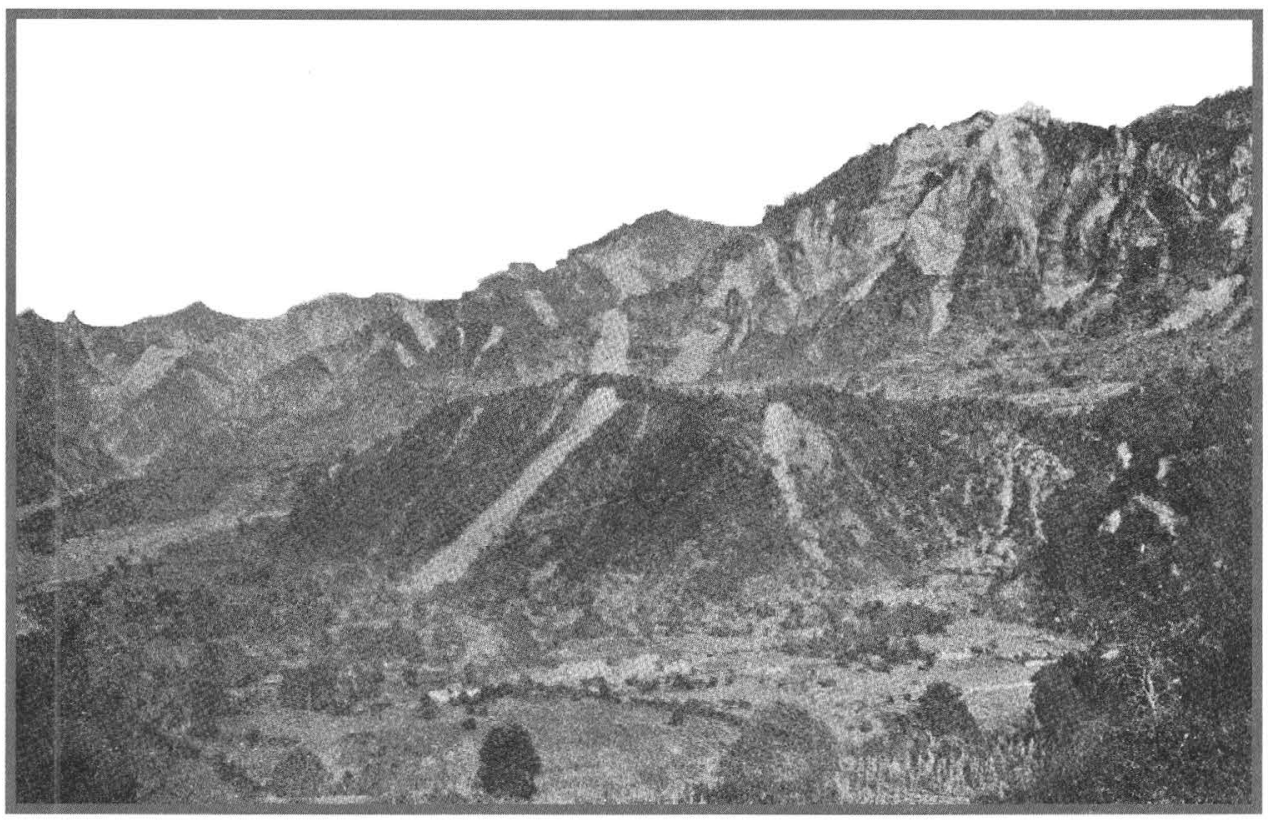

Figure 14. Photograph of hillslopes upstream of Barranca Grande, following earthquake of Jan. 3, 1920. Reprinted from Plate VI-A, Instituto Geológico de México (1922). 
Table 2: Velocities of flow fronts and peak-flow velocities of several seismogenic debris flows discussed in text. [km, kilometers; $\mathrm{km} / \mathrm{hr}$, kilometers per hour; $\mathrm{m} / \mathrm{s}$, meters per second]

\begin{tabular}{|c|c|c|c|}
\hline Case history & $\begin{array}{l}\text { Average velocity of } \\
\text { flow front }(\mathrm{km} / \mathrm{hr})\end{array}$ & $\begin{array}{l}\text { Channel reach } \\
\text { or point }(\mathrm{km})\end{array}$ & $\begin{array}{l}\text { Peak-flow velocity at } \\
\text { distance from source } \\
\text { (m/s@ } @ \text { km) }\end{array}$ \\
\hline $\begin{array}{l}1994 \text { Colombia } \\
\text { (Río Paez) }\end{array}$ & $\begin{array}{l}>60 \\
60-90\end{array}$ & $\begin{array}{c}0-9.4 \\
0-30.3\end{array}$ & \\
\hline & & & $\begin{array}{c}14.1 @ 43.1^{*} \\
8-12 @ ?^{\dagger}\end{array}$ \\
\hline 1920 Mexico & & & $\begin{array}{l}>30 @ \sim 5-10^{*}, \S \\
>20 @ \sim 5-10^{\S}, \#\end{array}$ \\
\hline 1960 Chile & $>30$ & $\sim 2^{* * *}$ & \\
\hline \multicolumn{4}{|l|}{1970 Peru $^{\dagger \dagger}$} \\
\hline Proximal debris avalanche & 280 & $0-16$ & \\
\hline Debris flow & 60 & $16-31$ & \\
\hline Distal debris flow & 30 & $>31^{\S \S}$ & \\
\hline 1987 Ecuador & & & $>15.0$ @ $10-30^{\# \#}$ \\
\hline
\end{tabular}

* Measurement of runup or interpreted from observation of runup (cf., Pierson, 1985).

† Reported by Avila and others (1995) at unknown locations for "initial field observations" and the accounts of inhabitants; believed to be mainly from downstream locations.

$\S$ Based on observations by Camacho (1922).

\# Interpreted from observation of superelevation (cf., Pierson, 1985).

** Based on observation of flow overtaking a galloping horse (Wright and Mella, 1963, p. 1383).

t† Eyewitness accounts combined with runup and superelevation measurements (Plafker and Ericksen, 1975).

$\S \S$ Recorded "far downstream" (Plafker and Ericksen, 1975).

\# Based on observations of Ishihara and Nakamura (1987), Nieto and others (1991), and Schuster and others (1996).

have traveled farther or they may have catastrophically displaced part of a smaller body water to create a flood surge.

\section{Ecuador, 1987}

Two earthquakes (M 6.1 and 6.9) caused a similar landscape response in Ecuador on March 5, 1987, from and near Volcán Reventador (Nieto and others, 1991; Schuster and others, 1996; Schuster, 2001). “...a large percentage of this huge mass of material (from seismically triggered mudslides and debris avalanches on and near Reventador) combined with water (in channels)...to form thick debris flows that descended...tributaries of the upper Amazon" (Nieto and others, 1991, p. 73). On steep slopes underlain by lateritic soils and tuff, "slope failures commonly started as thin slides, which rapidly turned into fluid debris avalanches and debris flows" (Schuster and others, 1996).

The runout distance of the debris flows is unrecorded, but flows were described as extending from the headwaters of the Río Due to beyond its confluence with the Río Aquario, a distance of over $50 \mathrm{~km}$ (Ishihara and Nakamura, 1987). Schuster and others (1996, fig. 16) recorded trimlines $8 \mathrm{~m}$ above river level $10 \mathrm{~km}$ downstream from the confluence. Thus, debris flows probably extended at least $60 \mathrm{~km}$. Estimates of the total volume of the slides and flows ranged from 75 to 110 million $\mathrm{m}^{3}$. 


\section{DEBRIS FLOWS FROM VOLCANO COLLAPSE}

We can probably assume that all sector collapses $\left(>1 \mathrm{~km}^{3}\right)$ are related to magmatic eruptions or, as in the famous 1888 collapse of Mount Bandai in Japan, probable phreatomagmatic eruptions (interpreted as phreatic by Siebert and others, 1987). This association, however, has led to underestimation of the potential for lahars beginning as collapses to be other than one of a group of eruptionrelated volcanic hazards. Other scenarios and nonmagmatic triggers must be considered now that we recognize that smaller volcanic landslides, those we call flank collapses, can also transform to far-reaching debris flows that enlarge significantly by bulking after they leave the volcano.

Of the flows in tables 3 and 4, the synchronous Osceola and Paradise are directly linked by stratigraphic evidence to eruptive activity at Mount Rainier (Vallance, 1995; Vallance and Scott, 1997). Within the limits of accuracy of radiocarbon dating, many of the largest flows at Rainier (table 3) occurred near or at the times of magmatic eruptions (Vallance, 1995; Vallance and Donoghue, 1999; Sisson and others, 2001) and were probably associated with magmatism directly or indirectly. The largest flows at Mount Baker occurred during a single magmatic cycle, first with magmatic destabilization (Park Creek and Middle Fork Nooksack River lahars) and then with phreatomagmatic activity (Ridley Creek lahar) that culminated in a magmatic eruption. Two flows at Rainier occurred near the times of paleoearthquakes (Events $\mathrm{N}$ and L; Atwater and Hemphill-Haley, 1997) but they cannot be correlated with those events. A significant flow at Mount Baker (Morovitz Creek lahar, table 3) followed a major hydrovolcanic and probable phreatomagmatic explosion (A.D. 1843) within weeks to months. The historic flows after the late Neoglacial maximum of A.D. 1850 (table 4) resulted from gravitational collapse, although hydrovolcanic activity has been suggested as a possibility in several instances.

The confidence limits on ages determined by radiocarbon dating complicate the correlation of collapses with either paleoearthquakes or the episodes of magmatic activity recorded by tephras. For planning hazard mitigation, this increases the importance of historic events, like the case histories described here, as well as those for which the chronology and sequence of events can be well established, like the association of a sector collapse with a blast deposit, or the reconstruction of the A.D. 1843 events at Mount Baker.

Our concluding discussion of mitigation strategies is based on the two primary factors that we emphasize herein-the mobility of debris flows beginning as volcanic landslides, and their ability to increase in volume by bulking as they flow long distances from a volcano. Triggering mechanism is a factor that adds a significant element of unpredictability. In the case of most collapses-directly or indirectly magmatically triggered-precursory signs of magmatic activity will be recognized, and we can hope they will be acted upon to the extent that the downstream flow pathways will be evacuated. Nevertheless, uncertainty of an effective pre-event warning is created both by the difficulties in ordering an evacuation, and by the potential for unanticipated flows. To emphasize this point, in the following sections we summarize the possibilities for volcanic landslides to occur other than at times of magmatic eruption.

\section{Magmatic Destabilization}

Collapse may be triggered by magmatic intrusion whether an eruption occurs or not, and even whether magma intrudes and destabilizes the edifice directly or not. For example, 10 magmatic episodes that climaxed in plinian eruptions (sustained jets yielding large volumes of pumice) are believed to have triggered sector collapses after the onset of magma ascent but before intrusion within the edifice (Belousova and others, 1998). Where collapse is not associated with an eruption that yielded juvenile material, ascent or intrusion of magma may have begun at depth but simply not have continued to eruption. During magma ascent into an edifice, collapse itself may unload an edifice sufficiently to be the trigger of a large magmatic eruption, as at Mount St. Helens in 1980 and at Bezymianny and Shiveluch volcanoes in Kamchatka in 1956 
Table 3. Cohesive debris flows of Holocene age formed by transformation of flank and sector collapses on Mount Rainier and Mount Baker — [km, kilometers $]$

\begin{tabular}{|c|c|c|c|c|}
\hline Volcano and flow & $\mathrm{Age}^{*}$ & $\begin{array}{l}\text { Volume } \\
\left(\mathrm{km}^{3}\right)\end{array}$ & $\begin{array}{l}\text { Known runout } \\
\text { distance }(\mathrm{km})\end{array}$ & $\begin{array}{l}\text { References } \\
\text { and notes }\end{array}$ \\
\hline \multicolumn{5}{|l|}{ MOUNT RAINIER } \\
\hline Tahoma Lahar & $\begin{array}{c}\sim 400 \\
\text { (calendar years) }\end{array}$ & $\sim 0.10$ & $>18$ & $\begin{array}{l}\text { Scott and others (1995); } \\
\text { volume revised down }\end{array}$ \\
\hline Electron Mudflow & $\begin{array}{c}\sim 500 \\
\text { (calendar years) }\end{array}$ & 0.23 & $\begin{array}{c}68 \\
\text { (Puget Sound) }\end{array}$ & $\begin{array}{l}\text { Crandell (1971); Scott and } \\
\text { others (1995); P.T. Pringle } \\
\text { (personal commun., 2001) }\end{array}$ \\
\hline "1,000-yr-old" lahar & 1,000 & $<\sim 0.20$ & $>24$ & $\begin{array}{l}\text { Crandell (1971); volume } \\
\text { revised down }\end{array}$ \\
\hline Round Pass Mudflow & $\begin{array}{c}2,600 \pm 155 \\
\text { (Puyallup River) }\end{array}$ & $>0.40$ & $>31$ & $\begin{array}{l}\text { Crandell (1971); Scott and } \\
\text { others (1995) }\end{array}$ \\
\hline Round Pass Mudflow & $\begin{array}{c}2,600 \pm 50 \\
\text { (Nisqually River) }\end{array}$ & 0.17 & $>25$ & $\begin{array}{l}\text { Crandell (1971); Scott and } \\
\text { others (1995); this report }\end{array}$ \\
\hline Unnamed lahar & $2,900 \pm 60$ & $\sim 0.15$ & $>14$ & This report \\
\hline "Pre-Y Lahar" & $3,490 \pm 60$ & $\sim 0.15$ & $>36$ & $\begin{array}{l}\text { Crandell (1971); Scott and } \\
\text { others (1995); this report }\end{array}$ \\
\hline Osceola Mudflow & $4,832 \pm 43$ & 3.8 & $\begin{array}{c}125 \\
\text { (Puget Sound) }\end{array}$ & $\begin{array}{l}\text { Crandell (1971); Vallance } \\
\text { and Scott (1997) }\end{array}$ \\
\hline Paradise Lahar & $\begin{array}{c}\text { same age as } \\
\text { Osceola Mudflow }\end{array}$ & 0.10 & $>36$ & $\begin{array}{l}\text { Crandell (1971); Scott and } \\
\text { others (1995) }\end{array}$ \\
\hline \multicolumn{5}{|l|}{ MOUNT BAKER $\#$} \\
\hline Lahar from Sherman Crater & $\begin{array}{c}\text { Post A.D. } 1847 \\
\text { (1858?) }\end{array}$ & 0.002 & $>12.5$ & This report \\
\hline Morovitz Creek lahar & A.D. $1845-1847$ & $0.02-0.03$ & $\begin{array}{c}>15 \\
\text { (to natural } \\
\text { Baker Lake) }\end{array}$ & $\begin{array}{l}\text { Scott and others }(2000) \\
\text { this report }\end{array}$ \\
\hline Ridley Creek lahar & $\begin{array}{l}5,700 \pm 50- \\
5,900 \pm 50\end{array}$ & $\sim 0.10$ & $>33$ & This report \\
\hline $\begin{array}{l}\text { Middle Fork Nooksack } \\
\text { River lahar }\end{array}$ & $\sim 5,900 \pm 50$ & $\sim 0.20$ & $>44 \dagger$ & $\begin{array}{l}\text { Scott and others }(2000) \\
\text { this report }\end{array}$ \\
\hline ParkCreeklahar & $\sim 5,930 \pm 50$ & $\sim 0.05$ & $>15$ & $\begin{array}{l}\text { Scott and others }(2000) \\
\text { this report }\end{array}$ \\
\hline Schriebers Meadow lahar & $\sim 8,500 \pm 70$ & $\sim 0.02$ & $>9$ & $\begin{array}{l}\text { Scott and others (2000); } \\
\text { this report }\end{array}$ \\
\hline
\end{tabular}

* Ages are in radiocarbon years before present unless otherwise indicated.

$\dagger$ Known runout distance is $44 \mathrm{~km}$ (Dragovich and others, 1997) to elevation $20 \mathrm{~m}$ in the Nooksack River (P.T. Pringle, written commun., 1997); probably $>60 \mathrm{~km}$ to mid-Holocene coastal area of Puget Sound.

\# Magmatic tephras: SP, 10,870 \pm 80 ; SC, 8,830 \pm 30 ; BA, 5,740 \pm 50. Phreatomagmatic tephras: $0 P, 5,800 \pm 50$; YP, A.D. 1843 
Table 4. Debris avalanches (post-A.D. 1850) from Mount Rainier and Mount Baker. [km, kilometers]

\begin{tabular}{|c|c|c|c|c|}
\hline Volcano and flow & Date & $\begin{array}{l}\text { Volume } \\
\left(\mathrm{km}^{3}\right)\end{array}$ & $\begin{array}{c}\text { Avalanche } \\
\text { runout distance } \\
(\mathrm{km})\end{array}$ & References \\
\hline \multicolumn{5}{|l|}{ MOUNT RAINIER } \\
\hline $\begin{array}{l}\text { Tahoma Glacier } \\
\text { debris avalanche }\end{array}$ & $1910-1927$ & 0.004 & 7.2 & $\begin{array}{l}\text { Crandell (1971); Scott and } \\
\text { Vallance (1995) }\end{array}$ \\
\hline $\begin{array}{l}\text { Carbon Glacier } \\
\text { rockslide }\end{array}$ & 1916 & $\sim 0.006$ & $>6.0$ & $\begin{array}{l}\text { Driedger (1986); Scott and } \\
\text { Vallance (1995) }\end{array}$ \\
\hline $\begin{array}{l}\text { Little Tahoma Peak } \\
\text { debris avalanche(s) }\end{array}$ & 1963 & 0.011 & 7.5 & $\begin{array}{l}\text { * Crandell and Fahnestock } \\
\text { (1965); Scott and Vallance } \\
\text { (1995) }\end{array}$ \\
\hline $\begin{array}{l}\text { Curtis Ridge } \\
\quad \text { debris avalanche }\end{array}$ & 1989 & $<0.001$ & 4.4 & $\begin{array}{l}\text { Norris (1994); Scott and } \\
\text { Vallance (1995) }\end{array}$ \\
\hline $\begin{array}{l}\text { Curtis Ridge } \\
\text { debris avalanche }\end{array}$ & 1992 & $<<0.001$ & 2.0 & Norris (1994) \\
\hline \multicolumn{5}{|l|}{ MOUNT BAKER } \\
\hline $\begin{array}{l}\text { Avalanche Gorge } \\
\text { debris avalanche } \\
\text { (debris avalanche transformed } \\
\text { to cohesive debris flow) }\end{array}$ & $1890-1891$ & 0.020 & 10.5 & $\begin{array}{l}\dagger \text { Hyde and Crandell (1978); } \\
\text { Fuller (1980); this report }\end{array}$ \\
\hline $\begin{array}{l}\text { Boulder Glacier } \\
\text { debris avalanches }\end{array}$ & $\begin{array}{l}1960,1962 \\
1969,1973\end{array}$ & $<<0.001$ & $2.1-2.6$ & Frank and others (1975) \\
\hline
\end{tabular}

* Flow(s) may have extended significantly farther if not dammed by a Neoglacial terminal moraine. Small secondary debris flow continued downstream.

$\dagger$ Flow is a cohesive debris flow ( $>6.0 \%$ clay) by $\mathrm{km} 8.5$. Source rock is mainly a mid-Pleistocene unit mapped as "andesite of Lava Divide" by W. Hildreth (written commun., 1997).

and 1964, respectively (Belousov and Bogoyavlenskaya, 1988; Belousov, 1995).

Surface inflation with initial injection of magma into the subvolcanic crust within $5 \mathrm{~km}$ of the surface can readily be detected with adequate geodetic monitoring (Dzurisin, 1998). Nevertheless, collapse potentially may occur so early in a magmatic episode that staged alert levels may not have reached the point at which eruption is believed to impend and thus flow pathways are evacuated. Collapse probability will begin to increase as soon as magmatic activity is detected and will continue to increase as it proceeds.

\section{Rainfall}

The role of water in destabilizing source material and in mobilizing landslides of all types is pervasive. Multiple, mainly asynchronous failures triggered by rapid infiltration and slope erosion in all steeplands are common during major storms, but are especially so in volcanic terrains as in the case of Sarno, Italy, described above.

The most recent example of a single, catastrophic flank collapse was the 1998 failure of part of the edifice of Volcán Casita in Nicaragua in response to precipitation from Hurricane Mitch. A single landslide transformed to a debris flow that took 2,500 lives and destroyed two towns $7 \mathrm{~km}$ downstream (Scott, 2000). The flow wave enlarged by mobilizing and eroding surficial deposits, increasing in volume by several times relative to the contributing volume of the flank collapse. The flank collapse yielded a hyperconcentrated flood with separation of 
coarse bedload on the edifice flank, but then, beyond the base of the edifice, mobilized saturated surficial material to bulk and transform to the catastrophic debris flow. The two "new towns," sited in a prehistorically active debris flow pathway, were obliterated by the $3.5-\mathrm{m}$ deep, 1.2-km-wide debris flow.

\section{Earthquakes}

Stratovolcanic edifices in tectonically active belts are obvious source areas of seismogenic landslides. The potential for volcanic landslides triggered by earthquakes of nonmagmatic origin is indicated by the case histories discussed here and by the general frequency and hazards of historic landslides triggered by tectonic earthquakes (Keefer, 1984). About 35 percent of historic landslides that blocked and dammed drainages were caused by earthquakes (Costa and Schuster, 1991). Post (1967) recorded numerous landslides triggered by the 1964 M 8.4 Alaska earthquake.

The seismogenesis of many large prehistoric landslides in the Pacific Northwest is based on correlation of the ages of multiple radiocarbondated failures with the times, also radiocarbondated, of both crustal and subduction-zone paleoearthquakes (Schuster and others, 1992 and 1995; Engebretson and others, 1996; Pringle and others, 1998). No significant correlation is yet apparent, however, between the times of the most recent subduction-zone paleoearthquakes and the times of volcano collapse in the Cascade Range. However, based on the reported numbers of large landslides that have been linked to paleoearthquakes in the Cascade Range and the Pacific Northwest, for seismogenic volcano collapses to be other than a significant hazard, the altered rocks of stratovolcanoes will have to shown to be more stable than the ancient eroded terrains that yielded these landslides.

Volcanoes are subject to earthquakes related to regional tectonic forces, to gravitational forces related to the progressive disintegration of an edifice, to forces associated with cooling magma bodies and the resulting hydrothermal circulation, and to edifice effects-gravitational forces relating to loading of the crust by the mass of the volcano (Moran, 1997). Mount Rainier, for example, is relatively seismically active (Malone, 1996; Malone and Moran, 1997), but the source of the stresses for the abundant shallow earthquakes centered beneath the volcano is unknown (Moran, 1997). Nearby seismic zones are potential sources of an earthquake large enough to trigger a flank collapse (Moran, 1997, p. 17, 120-121).

Volcanoes in Nicaragua have yielded several catastrophic flows in addition to the collapse of Volcán Casita in 1998. Two of those flows, at Mombacho in A.D. 1570 with about 400 fatalities and at Cosiguiina in 1950 with about 1,000 deaths, were seismogenic (W. Strauch, personal commun., 1999). Both triggering earthquakes are believed by Strauch to have been tectonic in origin.

A $0.034 \mathrm{~km}^{3}$-flank collapse was triggered by a reportedly tectonic earthquake (M 6.8), yielding a $0.056-\mathrm{km}^{3}$ debris avalanche (volume increased by bulking) at Ontake Volcano, Japan, in 1984 (Inokuchi, 1985; Endo and others, 1989).

Earthquakes may also trigger noncohesive flows in volcanic zones. A granular debris flow formed by bulking of a glacier-outburst flood with proglacial alluvial deposits in Peru on January 13, 1998, apparently as a delayed response to several earthquakes, the first and largest (M 5.5) at 23:55 hours on January 9. The debris flow traveled over $20 \mathrm{~km}$ from Nevado Sacsarayoc in the Río Sacsara to cause 18 fatalities in the villages of Yanatile and Santa Teresa, $10 \mathrm{~km}$ west of Machu Picchu. Investigations by one of us (Macías) indicate that fatalities were significantly reduced by villagers' awareness of the danger of debris flows, some possibly seismogenic, from past history. Alluvial terraces contain the deposits of at least three previous noncohesive debris flows. An event warning came from the noise of the flow, described by villagers as so loud it was heard in the adjoining valley of the Río Santa Teresa.

\section{Gravity}

The potential for gravitational collapse without a discrete triggering event relates to the continuous weakening of the edifice by alteration 
possibly combined with such progressively destabilizing changes as tectonic tilting (Johnson, 1987; Siebe and others, 1992), tectonic spreading (van Wyk de Vries and Francis, 1997; van Wyk de Vries and others, 2000), faulting (Alloway and others, 1986), sea level changes at coastal volcanoes (Wallmann and others, 1988), or the debuttressing effects of erosion (Day, 1996) or glacial recession (Scott and Vallance, 1995, sheet 2). Collapse may simply occur as weakness progresses to some unknowable point at some unknowable time. Lopez and Williams (1993) make a general case for collapses related primarily to the instability caused by hydro-thermal processes, with failure presumably triggered by a variety of events. In the words of Hoblitt and others (1998), "like a house infested with termites, the affected part of the volcano eventually becomes so weak that it collapses under its own weight," and thereby generates a cohesive-debris flow or debris avalanche.

Small historic debris avalanches and rockslides, with volumes less than approximately $0.020 \mathrm{~km}^{3}$, have occurred at Mounts Rainier and Baker since the initiation of Neoglacial recession about A.D. 1850 (table 4). Of the flows in Table 4, only the Avalanche Gorge debris avalanche at Mount Baker in A.D. 1890-1891 transformed to a cohesive debris flow. Hydrovolcanic activity is considered a possibility in the triggering of several of these events (for example, Crandell and Fahnestock, 1965), but most have no explanation other than gravitational collapse. Debuttressing of unstable slopes by the progressive loss of Neoglacial ice over the last 150 years is possibly a contributing factor. These historic collapses, with runouts extending as much as $10.5 \mathrm{~km}$ from the base of a Cascade Range volcano, can be interpreted as part of a population of gravitational collapses that may include examples large enough to transform to debris flows that will extend to more highly populated areas.

\section{Hydrovolcanic Activity (Phreatic and Phreatomagmatic)}

Phreatic activity at a volcano is described by Francis (1993) as resulting from small amounts of water coming in contact with hot volcanic rock, not necessarily molten magma, and producing small-scale steam explosions; phreatomagmatic activity is described as resulting from generally larger amounts of water interacting directly with magma to produce violently explosive eruptions. Therefore, phreatic tephras consist of lithic, non-juvenile material, whereas phreatomagmatic tephras contain juvenile material. This necessarily tephra-based distinction creates a black-or-white classification of the events recorded in eruptive products that can be misleading in, for example, a purely lithic tephra from an explosion related to magma too deep to be incorporated in the tephra. There is a spectrum of interactions involving various degrees of linkage between water, hot rock, and magma that are best described generically as hydrovolcanic activity. As evidence accumulates of a relationship or lack thereof with magma, activity can be described as phreatic or phreatomagmatic. For example, the tephra produced by a large hydrovolcanic explosion triggering the largest collapses at Mount Baker consists of altered lithics, with a trace component of equivocally juvenile material. Nevertheless, we consider that eruption as phreatomagmatic because it was closely followed by a magmatic eruption.

The $1.5-\mathrm{km}^{3}$ sector collapse at Bandai Volcano in Japan in A.D. 1888 is widely cited as having been triggered by phreatic eruptions with no magmatic component (for example, Siebert and others, 1987; Nakamura and Glicken, 1997). However, at the time of his death in 1991, Harry Glicken (personal commun., 1991) was investigating the possibility of that event being related to a local deposit of a lateral blast that may contain juvenile material. That association remains unconfirmed.

\section{Triggering Mechanisms Related to Possibility of Pre-event Warning}

In planning mitigation for cities near volcanoes, a burden of certainty rests on the assumption that collapse will be preceded by magmatic activity that is detected, recognized, and acted upon by evacuating and sustaining the evacua- 
tions in potential flow pathways. Even if collapse is certain to be associated with magmatic activity and thus can be anticipated, can it be anticipated to the degree that evacuations of cities at risk far downstream have been ordered and completed? It is the remarkable ability of debris flows to extend to lowlands many tens of $\mathrm{km}$ beyond the edifice that makes the hazardous potential of cohesive debris flows so difficult to comprehend and appreciate. Mount Rainier, draining to communities that are suburbs of Tacoma and Seattle, Washington, is an example of this dilemma, in that sustained evacuation of flow pathways there could disable an economy of regional scale.

Earthquakes, gravitational forces, and rainfall are triggers without useful or detectable precursors. Hydrovolcanic explosions, if phreatic and not phreatomagmatic, may likewise occur without precursors. Phreatic explosions are "common, if rather minor" (Francis, 1993), and have been considered possible triggers of some historic landslides at Cascade Range volcanoes (Crandell, 1971; Crandell and Fahnestock, 1965). Mount Rainier is now, following significant Neoglacial recession, covered by $4.2 \mathrm{~km}^{3}$ of snow and ice (Driedger and Kennard, 1986). Thus, it has probably been the site of numerous phreatomagmatic as well as purely phreatic explosions at various scales throughout eruptive and quiescent periods of the Holocene.

The net result of the above summary is that flank collapse, at a scale potentially catastrophic at a Cascade Range volcano and elsewhere, is a hazard that is both a significant syneruptive volcanic hazard that can be predicted, and a hazard relating only to the presence of large volumes of weak, unstable and probably saturated material underlying steep slopes at high altitudes in tectonically active zones. No effective pre-event warning of a catastrophic debris flow can be assured for many communities in volcanic terrains, as survivors near volcanoes such as Nevado del Ruiz and Nevado del Huila (Colombia), Pico de Orizaba (Mexico), Osorno (Chile), Reventador (Ecuador), or Casita (Nicaragua) can attest.

\section{RECOGNITION OF VOLCANIC DEBRIS AVALANCHES AND COHESIVE DEBRIS FLOWS (LAHARS) FROM DEPOSITS}

Documenting past flows and their frequencies and mobilities is vital to assessing future volcanic flow hazards. Figure 15 attempts to show a general progression from a landslide of weak, altered material to cohesive debris flow. Variations on this theme are many, most notably in the distance over which the transformation can occur.

\section{Longitudinal Transformation and Textural Change}

Deposits show that megaclasts may dominate the larger flows for only a short distance. Flow transformation is so efficient that in many of the cases with which we are familiar (table 3) debris flow formation occurs within $1-5 \mathrm{~km}$ of source. Thereafter, the remaining megaclasts $(>1.0 \mathrm{~m}$ in diameter) are dispersed in an intermegaclast matrix consisting of clasts $(2 \mathrm{~mm}$ to $1 \mathrm{~m}$ in diameter) and matrix $(<2 \mathrm{~mm})$. Then, as these remaining mega-clasts disaggregate or are deposited, the intermegaclast matrix in effect becomes the debris flow that may travel upwards of $100 \mathrm{~km}$ without further transformation.

Subsequent longitudinal changes may consist of eventual complete loss of megaclasts, a higher clay content, and a higher proportion of lithologies bulked during flow. Megaclasts of poorly consolidated or weaker material contribute mainly to the finer matrix component of the developing intermegaclast matrix (fig. 2) or are deposited; megaclasts of more durable lithologies may fracture into both clasts and matrix material or be deposited (fig. 15, B-D). Any remaining megaclasts commonly protrude as mounds once deposition occurs, and their photogenic presence is the main reason that several hundred large volcanic debris avalanches have been recorded around the world. 
A few megaclasts may remain to form mounds on lateral and distal debris flow deposits (fig. 15, $\boldsymbol{B}$ and $\boldsymbol{C}$ ), in cases causing the flow to be incorrectly identified as a volcanic debris avalanche. Or, all the megaclasts may have disintegrated or been deposited upstream, so that the runout deposit lacks mounds (fig. 15, D) and may not be readily recognized. If it is identified, its moundless surface may cause it to be assessed as a separate flow unrelated to its upstream facies, probably identified there as a mound-bearing "debris avalanche."

Debris flows of all scales are characterized by the tendency for a concentration of the largest clasts at the moving flow front, which may correspond to or be closely followed by the peak stage and discharge. A progressive decline in clast size from the front to the tail of a single flow wave is a general characteristic of both large volcanic and small alpine debris flows, as illustrated by Sharp and Nobles (1953, fig. 3). Flow at the front is continuously cycled toward the channel boundaries, both to the sides and bottom, described by Johnson (1984) as being like the circular movement of a caterpillar-tractor tread as the tractor moves forward. In this model, flow toward the channel boundaries reverses and re-enters the main thread of the flow after the peak passes, again to move forward to the front to complete one in a series of continuous loops. Megaclasts moved in this way may get stranded in the shallows when the lateral flow reverses,

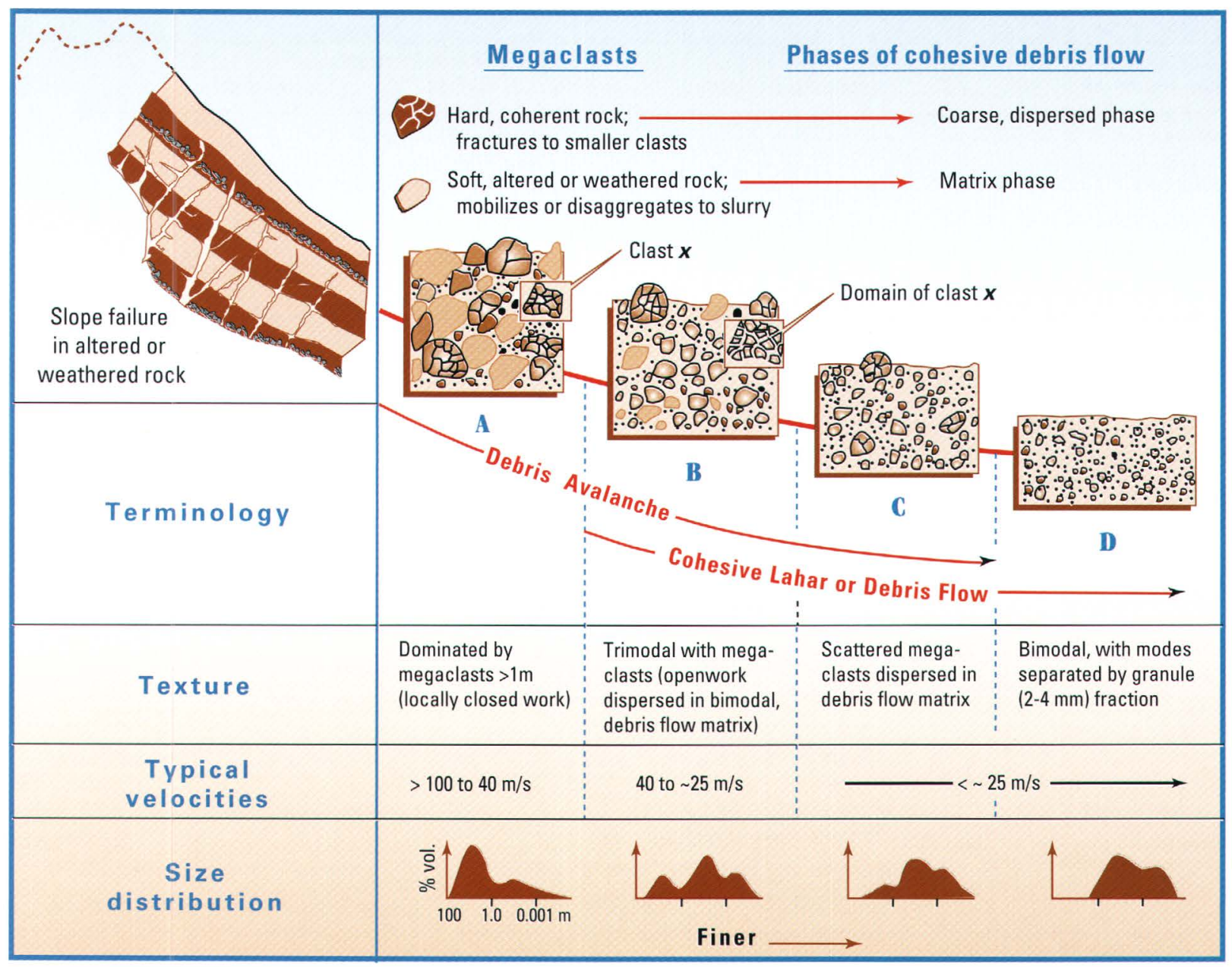

Figure 15. Diagrammatic portrayal of stages in formation of a cohesive debris flow or lahar, where the failed mass consists of similar amounts of hard, coherent rock and weak, readily disaggregated material. 
forming a megaclast-bearing lateral facies. With the variation superimposed by the bulking from channel sides of both consolidated and unconsolidated megaclasts (Scott, 1988b, fig. 8),

megaclasts generally get smaller downstream (Ui, 1981; Palmer and others, 1991).

\section{Interpreting Flows and their Behavior from their Deposits}

The best known volcanic debris avalanche began as a sector collapse at Mount St. Helens in 1980 (Glicken, 1996 and 1998). The megaclastrich and mounded deposits of that $2.5-\mathrm{km}^{3}$ flow (table 1) quickly stimulated the recognition of other debris avalanches on the basis of megaclasts and mounds. Its lack of direct transformation to debris flow and consequent low mobility became the behavioral model for the runout of a volcanic collapse, despite early descriptions of the deposits of some other mound-bearing collapse runouts as those of mudflows. For example, Escher (1925) described a mound-bearing flow deposit $\left(2.9 \mathrm{~km}^{3}\right)$ with "10,000 hills" (actually 3,600) that extended over $250 \mathrm{~km}^{2}$ below Galunggung Volcano in Indonesia as that of a "wet lahar." Likewise, McPhail (1973) described a typical volcanic debris avalanche $\left(>10 \mathrm{~km}^{3}\right)$ in Chile as the Río Teno Lahar.

Table 5. Inter-megaclast texture and mound density of a debris avalanche in the Río Teno, Chile (McPhail, 1973; Naranjo and others, 1997) and the 0sceola mudflow (Vallance and Scott, 1997).

$[\%$, percent; $\mathrm{km}$, kilometers]

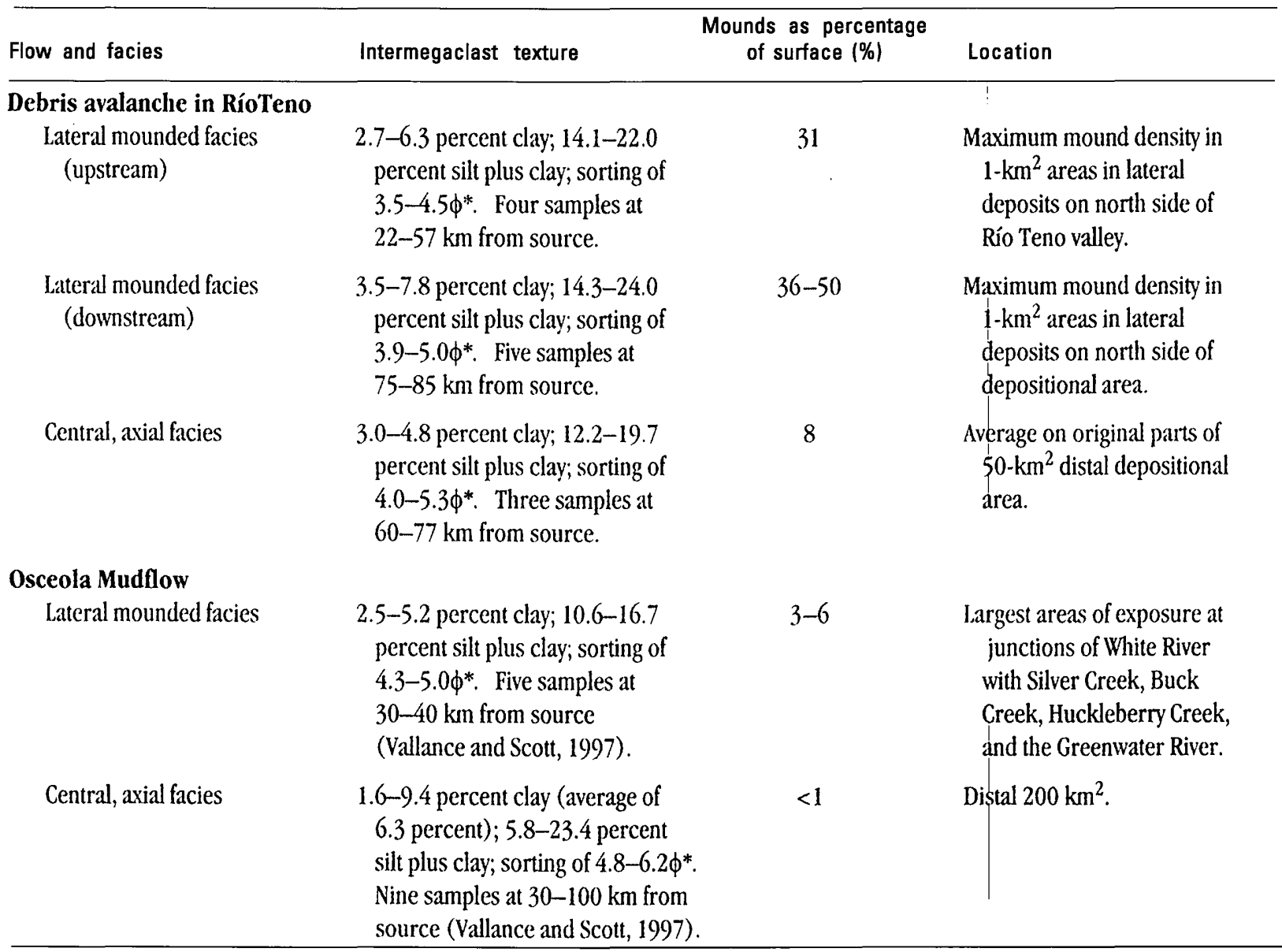

Note: Mound spacing based on aerial and ground photos at each location.

*Sorting as the inclusive graphic standard deviation defined by Folk (1980) as $\sigma_{1}=\left(\phi_{16}-\phi_{84}\right) / 4+\left(\phi_{5}-\phi_{95}\right) / 6.6$; $\phi$ values $=-\log _{2}$ (diameters in $\left.\mathrm{mm}\right)$. 
The textures of two volcanic debris avalanches are described in table 5-the Osceola Mudflow (Vallance and Scott, 1997), a cohesive lahar of which a mound-bearing lateral facies has been interpreted as a debris avalanche (fig. 16); and the volcanic debris avalanche in the Río Teno, Chile (fig. 17) with deposits that are in significant part those of a cohesive lahar. The surface percentages of mounds are indications of the percentages by weight of large megaclasts in the deposits, based on the equivalence of areal and weight percent (Kellerhalls and Bray, 1971). The intermegaclast matrix of these flow deposits preserves, not the grain flow of finer particles, but the slurry of debris flow. Where megaclasts are dispersed in a matrix with the texture of a cohesive debris flow, as in the examples in table 5 and $\boldsymbol{B}$ and $\boldsymbol{C}$ of figure 15, they define a debris flow that evolved from a debris avalanche. This is probably, in fact, an accurate description of a significant number of the deposits now described as those of volcanic debris avalanches.

Some well-known volcanic debris avalanches are clearly grain flows or granular flows, with or without interstitial water (debris avalanches sensu stricto). The flow of blocks in the block facies (runout to $17 \mathrm{~km}$ ) of the primary debris avalanche at Mount St. Helens in 1980 was as grain flow with air as a significant interstitial component in addition to water, water vapor, and juvenile gases (Glicken, 1996 and 1998). The flow process of the more mobile matrix facies (runout to $29 \mathrm{~km}$ ) is less clear; although deposits showed evidence of movement as a turbulent

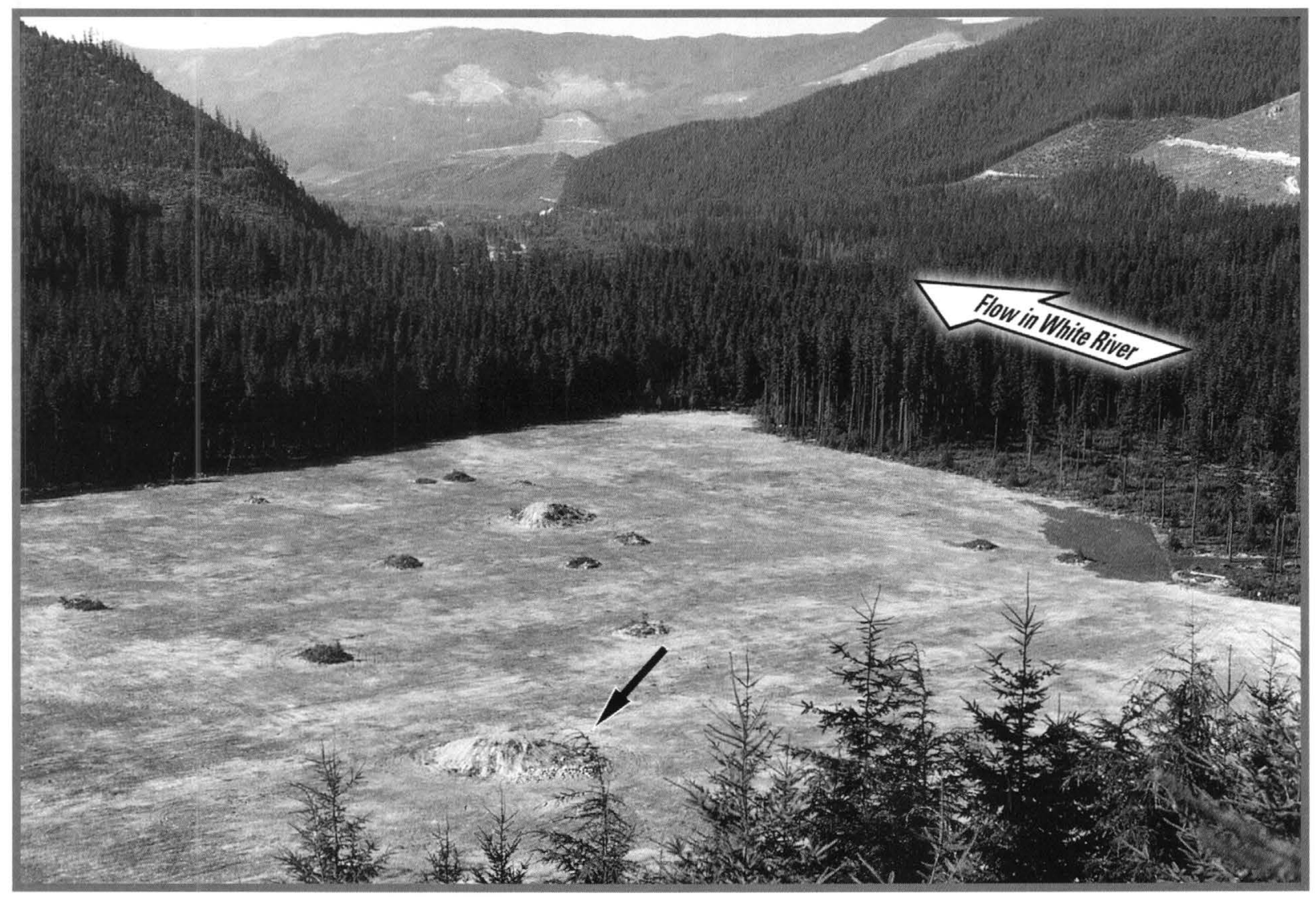

Figure 16. View of mounded surface of lateral facies of the Osceola Mudflow at Huckleberry Creek, $35 \mathrm{~km}$ downstream of source. View is downstream in the White River valley (arrow). The mounded deposits in the tributary embayment (Huckleberry Creek enters from left) represent deposits of peak flow that entered the embayment and then flowed back out, contributing to the recession stage and stranding some megaclasts. Largest mound in foreground is $12 \mathrm{~m}$ in maximum diameter (small arrow). 
fluid in which mixing occurred, complete transition to a fully mobile debris flow did not result (Glicken, 1996 and 1998). This partial transformation is represented by the transition from block facies to matrix facies of Glicken (1998, fig. 30), equivalent to the transition between $\mathrm{A}$ and $\mathrm{B}$ in figure 15. In early literature (Nakamura, 1978; Ui, 1983), volcanic debris avalanches were generically described as "dry", but this distinction was discarded with the recognition that most examples, like the 1980 flow at Mount St.

Helens, contained significant moisture.

Invaluable awareness of the frequency and hazards of the collapse runouts described as volcanic debris avalanches has resulted from the work of Ui (1983), Ui and others (1986), Siebert

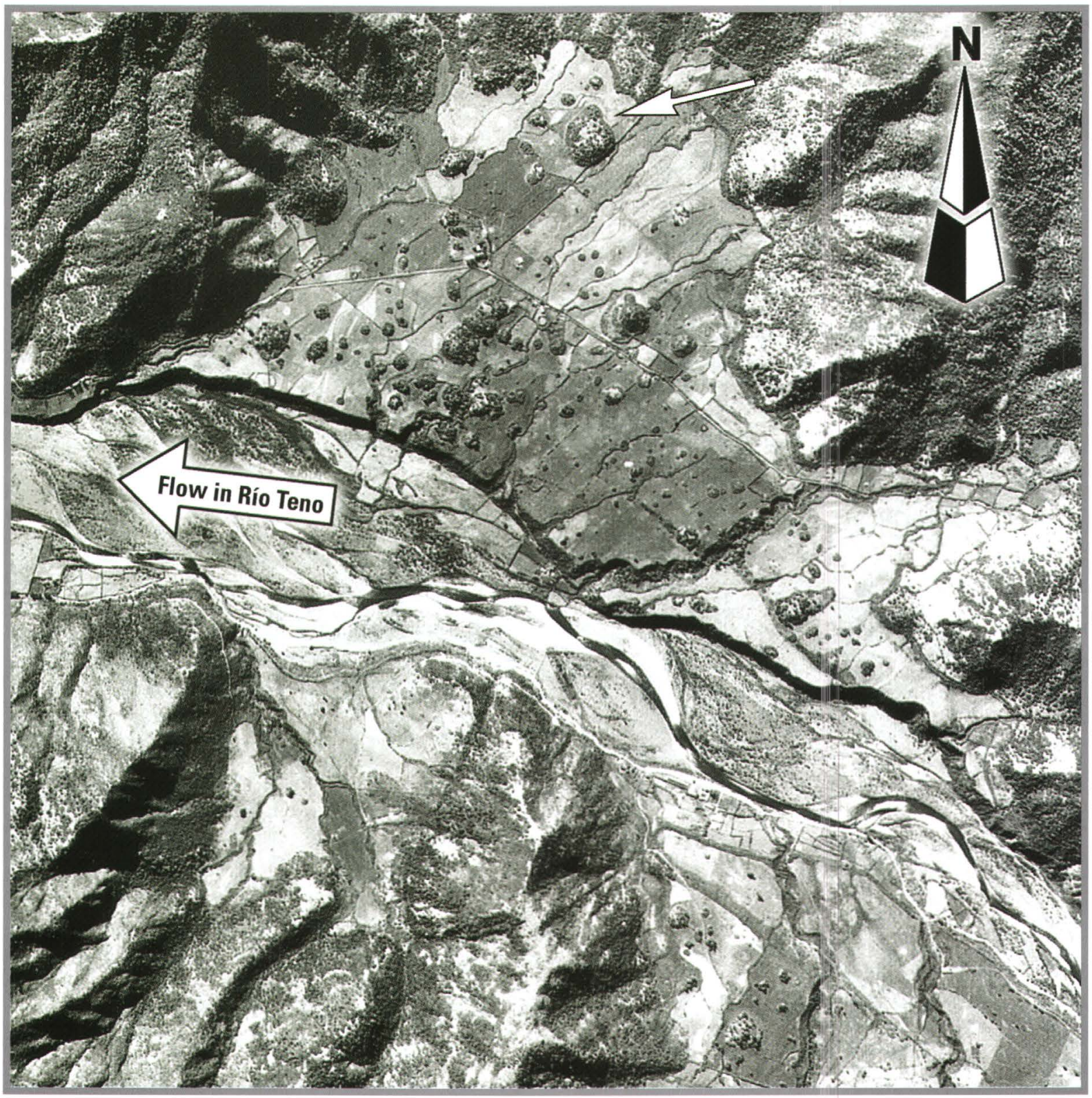

Figure 17. Aerial view of mounded surface of lateral deposits of the Río Teno debris avalanche (McPhail, 1973; Naranjo and others, 1997), 57 km downstream of source. Flow in the Río Teno is to left. Largest mound at north edge of embayment is $100 \mathrm{~m}$ in maximum diameter (small arrow). 
(1984 and 1996), and Siebert and others (1987). We believe this awareness is too valuable for perturbations by new terminology at this stage of our evolving knowledge about these flows. We suggest that for the present we continue to describe flows as those researchers have done. Although many volcanic debris avalanches may be better described as cohesive debris flows or lahars, the more important conclusion is that, as a consequence of identifying their distal deposits and true extent, their future analogs may be more mobile than we thought and that hazard assessment and mitigation strategies must be planned accordingly.

\section{Examples from Mount Rainier}

The series of Holocene-age flows at Mount Rainier, Washington, shows how mound-based interpretations may confuse cohesive debris flows and their high mobility, with debris avalanches and their limited mobility (tables 3 and 4). Most of the flows in table 3 began as a landslide, rapidly transformed to a debris avalanche, and then transformed directly to a cohesive lahar. For example, the $3.8-\mathrm{km}^{3}$ Osceola Mudflow (Crandell, 1971; Vallance and Scott, 1997) transformed and began to behave as a debris flow within the first two kilometers of flow. Adjacent to the axial Osceloa deposits are deposits with mounds (table 5; Vallance and Scott, fig. 1) that Crandell (1971) inferred was a pre-Osceola flow named the Greenwater lahar (figs. 16 and 18). Those lateral deposits were quite logically interpreted as those of a pre-Osceola debris avalanche (Siebert, 1984, table 1), but they subsequently were seen to be a lateral facies of the Osceola Mudflow (Vallance and Scott, 1997).

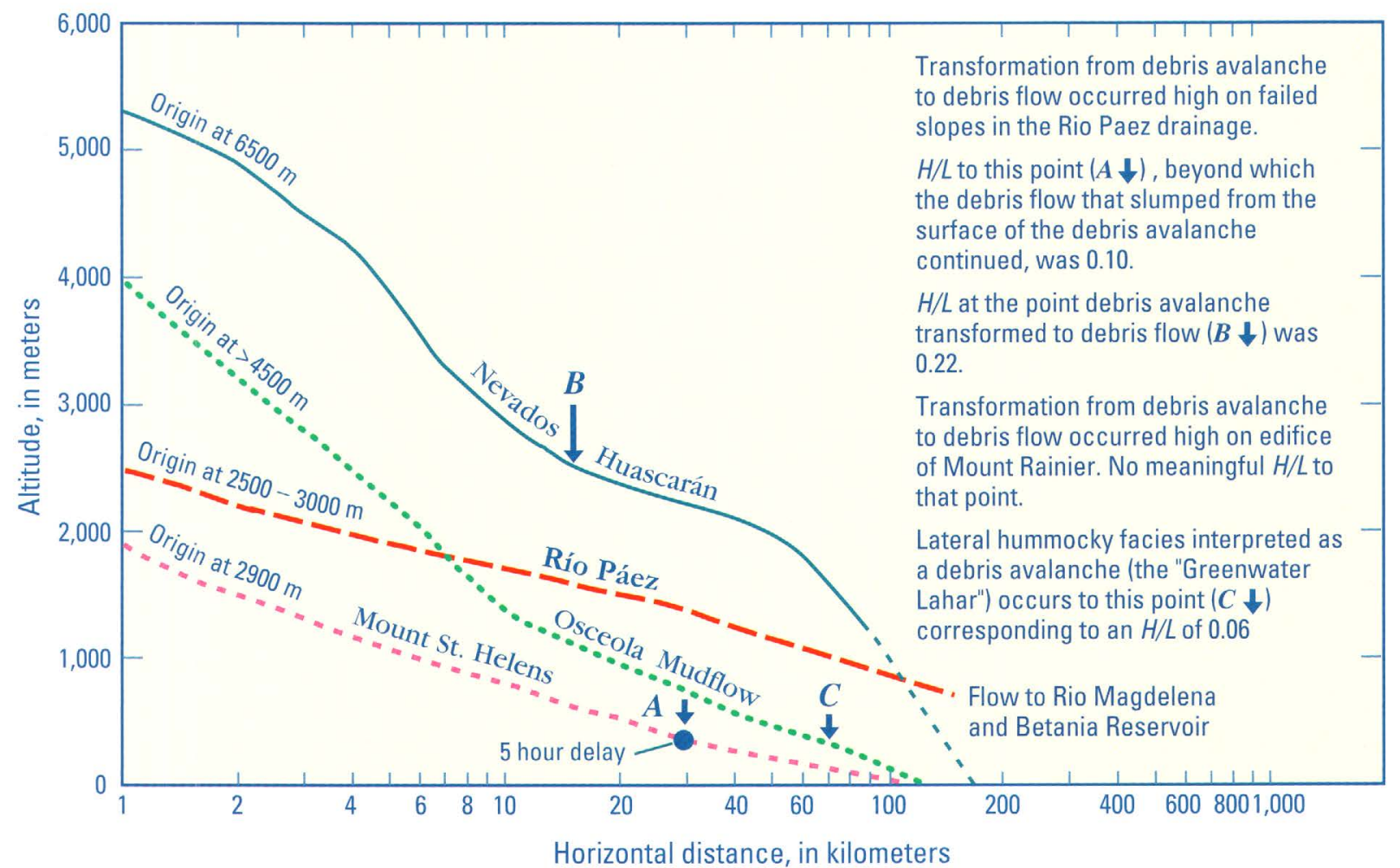

Figure 18. Longitudinal profiles of large, long-runout cohesive debris flows transformed or derived from slope failures and debris avalanches: Río Páez, 1994—this report; Mount St. Helens, 1980-Voight and others (1983), Fairchild (1987), Glicken (1996), and Scott (1988a); Nevados Huascarán, 1970—Plafker and Ericksen (1975); and Osceola Mudflow, prehistoric —Crandell (1971), Scott and others (1995), and Vallance and Scott (1997). 
The Osceola Mudflow began as a landslide and huge debris avalanche that, like the multiple slope failures from Nevado del Huila and the surrounding terrain drained by the Río Páez, quickly disintegrated to a slurry rafting a few megaclasts. These megaclasts were grounded in lateral backwater areas within the first $70 \mathrm{~km}$ to form the mounded Greenwater facies, with an apparent $H / L$ of 0.06 to that point (fig. 18). The flow actually continued $55 \mathrm{~km}$ farther, leaving a gigantic cohesive deposit with few megaclasts (about 30 according to Crandell, 1971) over 210 $\mathrm{km}^{2}$ of lowland plain before entering Puget Sound. Mound-bearing proximal portions of other cohesive debris flows at Mount Rainier could in similar fashion have been identified as separate flows and thus as debris avalanches.

\section{Examples from New Zealand}

Similar transformations and high mobility occur where debris avalanches spread, unconfined, on the relatively undissected, detritusmantled aprons (ring plains) of volcanoes such as Mounts Egmont and Ruapehu in New Zealand. In several cases, an axial-A facies with large megaclasts is deposited synchronously with a surrounding, finer-grained marginal axial-B facies rich in introduced (exotic) megaclasts (Palmer and others, 1991). A third facies is a marginal facies of cohesive debris flows (lahars). Flows characteristically spread and thin, to widths of as much as $10 \mathrm{~km}$ in the case of the Opua Formation at Mount Egmont (Neall, 1979, p. 22), and the associated lahars may reach as much as $60 \mathrm{~km}$ beyond the ring plains (Palmer and others, 1991). Although some marginal lahars may be contemporaneous failures from the area of initial collapse (Palmer and Neall, 1989), they are generally interpreted as direct transformations of matrix-rich avalanches (Palmer and others, 1991, p. 96). The pattern of the moremobile, finer-grained parts of a flow traveling beyond the initial coarse facies deposited axially (see fig. 8 of Palmer and others, 1991) corresponds strikingly to the behavior of the valleyconfined flows in table 3, in which finer-grained parts of a flow travel beyond the initial coarse facies deposited laterally (Vallance and Scott,
1997). In unconfined flows the axial facies of Palmer and others (1991) is the coarser material from the wave front; in confined flows the axial facies of Vallance and Scott (1997) is the finer material deposited during flow wave recession.

\section{DEBRIS FLOWS FROM LANDSLIDES AND VOLCANO COLLAPSES-FLOW MOBILITY}

The $H / L$ ratio or "equivalent coefficient of friction" (Heim, 1932; Shreve, 1968; cf., Iverson, 1997) applied originally to the distance moved by the center of gravity of a sliding block, but it has become a common measure of the mobility of debris avalanches and other flow types with less rigorous distinctions. Measurements of both $H$ (fall height) and $L$ (runout distance) may be approximations. For example, the original height of an edifice summit that failed in a sector collapse may be an estimate; and runout distance may be only the known extent of a flow which, for the reasons we present, may be greatly underestimated. Predictive limits of flow mobility, particularly of volcanic debris avalanches, are commonly expressed as minimum values of $H / L$. In practice, however, such values are more discussed than they are actually applied in order to distinguish the boundaries of safe and unsafe areas.

Because cohesive debris flows evolve directly from debris avalanches, any predictive $H / L$ is questionable if it was originally based on the more restricted extent of debris avalanches sensu stricto, those that do not transform beyond stage A, figure 15 . This uncertainly derives both from the high mobilities of the debris flows described here, and from the little-recognized frequency of transformation of debris avalanches to debris flows. Awareness of this transformation evolved gradually from Crandell's (1971) work describing the origin of the Osceola and Electron Mudflows at Mount Rainier.

At least two problems affect the data used in proposals of $H / L$ limits of the flows - described generally as volcanic debris avalanches - that are runouts of volcanic landslides. (1) As explained above, $L$ has commonly been based on mounded 
Table 6. Mobilities of volcanic debris avalanches expressed as $H / L$ values and evolution of $H / L$ values proposed to limit their extent.

$[H / L$, fall height/runout distance; $\mathrm{km}$, kilometers $]$

\begin{tabular}{|c|c|c|}
\hline$H / L$ & Reference & Observation or proposed use \\
\hline $0.06-0.18$ & Ui (1983) & $\begin{array}{l}\text { Reported range for volcanic debris avalanches thought to } \\
\text { be "dry." }\end{array}$ \\
\hline $0.06-0.2$ & Ui and others (1986) & Reported range for 71 avalanches in Japan. \\
\hline 0.11 & Siebert (1984) & $\begin{array}{l}\text { Median value (range } 0.05-0.02 \text { ) for } 73 \text { Quaternary debris } \\
\text { avalanches. }\end{array}$ \\
\hline 0.09 & Siebert (1996) & $\begin{array}{l}\text { Proposed as maximum runout distance for avalanches with } \\
\text { volumes between } 0.1 \text { and } 1 \mathrm{~km}^{3} \text {. }\end{array}$ \\
\hline 0.075 & Schuster and Crandell (1984) & $\begin{array}{l}\text { Proposed as basis for hazard analysis. Mean of } 11 \\
\text { representative debris avalanches with a volume of more } \\
\text { than } 10 \mathrm{~km}^{3} \text { is } 0.09 \text {. }\end{array}$ \\
\hline 0.075 & Crandell (1989) & $\begin{array}{l}\text { Proposed as limiting value, except where a "debris } \\
\text { avalanche becomes directly transformed into a mudflow } \\
\text { as it moves downvalley." }\end{array}$ \\
\hline 0.05 & Siebert and others (1987) & $\begin{array}{l}\text { Proposed as "worst case" value for "very large avalanches." } \\
\text { Values of } H / L \text { for } 41 \text { debris avalanches with a volume of } \\
\text { more than } 1 \mathrm{~km}^{3} \text { are } 0.05-0.13 \text {, with an average of } 0.09 \text {. }\end{array}$ \\
\hline 0.04 & $\begin{array}{l}\text { Carrasco-Nuñez and others } \\
\text { (1993) }\end{array}$ & For "runouts of large avalanche-induced lahars." \\
\hline 0.04 & Siebert (1996) & $\begin{array}{l}\text { Minimum value for avalanches }>1 \mathrm{~km}^{3} \text { in volume, but not } \\
\text { proposed as limiting value because of possible over- } \\
\text { estimation in many cases. }\end{array}$ \\
\hline$<0.02$ & This report & $\begin{array}{l}\text { No practical limit, with recognition that volcanic debris } \\
\text { avalanches commonly transform directly to cohesive } \\
\text { debris flows that increase in volume by bulking. }\end{array}$ \\
\hline
\end{tabular}

deposits. Consequently, the true extent of the flows, which as cohesive debris flows downstream may contain few or no megaclasts $(\boldsymbol{C}$ and $D$, fig. 15), may be understated. Measuring runout to the farthest downstream mounds commonly underestimates $L$. (2) Determining the true runout distances of debris flows without mounds can be difficult because of poor distal exposures, mantling deposits, little channel incision, inhospitable lowland conditions, and even urban development. However, the more the deposits of flows like those we describe from the Cascade Range are studied, the more mobile the flows are found to have been. Reflecting this trend, the proposals for use of limiting $H / L$ ratios have become progressively more cautious (table 6).
The cases discussed (tables 3 and 5) show that volcanic debris avalanches do not have practical limits. There is no $H / L$ that can represent a practical boundary between a dangerous area and a safe area. The potential $H / L$ for recurrence of most of the flows cited here is certainly $<0.02$ for channelized volcanic debris avalanches with a minimal volume on the order of $0.1 \mathrm{~km}^{3}$. Where the components of a flow are coherent, runout limits can more probably be constrained with an $H / L$ ratio, as in the approach of $\mathrm{Li}$ (1983). The behavior of these flows in some alpine settings may approach that of dominantly granular flows where runout distance is controlled by a coefficient of friction. However, the circumstances of the 1970 flow from Nevados Huascarán (tables 1 and 7; Plafker and 
Table 7: Examples of sources of incoherent material and fine sediment contributing to formation of cohesive debris flows.

\begin{tabular}{|c|c|c|c|}
\hline Source & Susceptible terrain & Water sources & Case histories \\
\hline $\begin{array}{l}\text { Weathered regolith } \\
\text { and bedrock }\end{array}$ & $\begin{array}{l}\text { Tropical, subtropical steeplands, } \\
\text { especially in volcanic zones }\end{array}$ & $\begin{array}{l}\text { Ground water of rainfall } \\
\text { origin }\end{array}$ & $\begin{array}{l}\text { Río Páez, 1994; Ecuador, 1987; } \\
\text { Mexico, } 1920 \text { (Table 1) }\end{array}$ \\
\hline \multirow[t]{2}{*}{$\begin{array}{l}\text { Hydrothermal alteration } \\
\text { of bedrock }\end{array}$} & $\begin{array}{l}\text { Stratovolcanoes of andesitic } \\
\text { composition }\end{array}$ & $\begin{array}{l}\text { Ground water of hydro- } \\
\text { thermal and rainfall } \\
\text { origin; snow and ice }\end{array}$ & $\begin{array}{l}\text { Mount Rainier, Mount Baker, } \\
\text { (Table 3) }\end{array}$ \\
\hline & $\begin{array}{l}\text { Stratovolcanoes of basaltic } \\
\text { composition }\end{array}$ & $-\mathrm{do-}$ & $\begin{array}{l}\text { Río Teno debris avalanche from } \\
\text { Volcán Planchón, Chile } \\
\text { (Table 5)* }\end{array}$ \\
\hline $\begin{array}{l}\text { Cataclasis (either fall- or } \\
\text { explosion-induced) }\end{array}$ & $\begin{array}{l}\text { Stratovolcanoes or bedrock } \\
\text { at high altitude in precipitous } \\
\text { terrain }\end{array}$ & $\begin{array}{l}\text { Ground water; snow and } \\
\text { ice; overrun surface } \\
\text { water }\end{array}$ & $\begin{array}{l}\text { Paradise Lahar (Crandell, 1971; } \\
\text { \$cott and others, 1995); } \\
\text { Nevados Huascarán (Table 1) }\end{array}$ \\
\hline $\begin{array}{l}\text { Primary surficial deposits } \\
\text { such as tephra } \\
\text { (weathering may } \\
\text { increase clay content) }\end{array}$ & $\begin{array}{l}\text { Steeplands near active } \\
\text { volcanoes }\end{array}$ & $\begin{array}{l}\text { Ground water of } \\
\text { rainfall origin }\end{array}$ & Lake Rupanco, Chile (Table 1) \\
\hline
\end{tabular}

Note: Other sources of both fine sediment and water are possible in each of the cited case histories.

*Significant contribution to matrix silt and clay was from cataclasis of relatively unaltered basalt.

Ericksen, 1975) and the debris avalanche from Volcán Planchón in the Río Teno, Chile (table 7) suggest general caution. In those cases, fine sediment facilitating the transformation of debris avalanche to debris flow was produced simply by cataclasis of coherent, relatively little-altered bedrock (granitoid at Huascarán; basaltic at Planchón) during avalanche flow.

Well-documented examples of large volcanic debris avalanches that did not transform directly to debris flows clearly exist. In addition to Mount St. Helens in 1980, they include collapses from Bezmianny and Shiveluch volcanoes in Kamchatka which produced debris avalanches with $H / L$ 's of 0.12 in 1956 and 0.14 in 1964, respectively (Belousov and Bogoyavlenskaya, 1988; Belousov, 1995). Nevertheless, the only area where a limited runout distance is sufficiently well documented to be applied as a prediction may be northern Chile, where remote sensing has documented flows with sharp flow fronts and which apparently did not completely transform to debris flows (for example, fig. 13.14 of Francis, 1993). In this extremely arid area- from edifices with no glaciers, almost no surface runoff, and presumably little ground watertransformation of a debris avalanche to debris flow presumably might not occur because of a low primary water content or a lack of surface water for entrainment. Possible examples include two debris avalanches from Socompa volcano (Francis and Self, 1987; Wadge and others, 1995; Day, 1996) which, without any reported transformation to debris flow, both ran to an $H / L$ of $<0.03$ (Francis and Self, 1987). Other explanations of high mobility (for example, Shreve, 1968; Melosh, 1987; Naranjo and Francis, 1987; Kobayashi, 1997; Davies and others, 1999) may well apply in such cases. Those flows suggest that, regardless of flow mechanism, the runout distance of debris avalanches is highly variable, and that the predictive value of any limitation is low.

Could less intense alteration (or weathering) be a significant additional factor in preventing complete transformation to a debris flow slurry? The 1980 debris avalanche at Mount St. Helens ran to an $H / L$ of 0.1 and stopped-for 5 hours 
before a cohesive debris flow (the type example; Scott and others, 1995) mobilized, possibly seismogenically (Fairchild, 1987), from the surficial avalanche deposit. Although the partial, delayed mobilization can be interpreted as the result of incomplete saturation (Voight and others, 1983), a contributing factor may also have been the relatively young age of the rocks in the 1980 avalanche. Although locally intense alteration can occur rapidly, the young age of the collapsed sector may have been insufficient for the degree of alteration necessary to create enough pervasive material weakness for direct transformation. Mount St. Helens is less than 40,000-50,000 years in age (Crandell, 1987); most if not all of the edifice that failed in 1980 (Glicken, 1996 and 1998) was less than about 2,500-3,000 years in age (Hausback and Swanson, 1990); and most of the upper part of the pre-1980 mountain was constructed in the last few hundred years (Crandell and others, 1975). In contrast, most other stratovolcanoes with active hydrothermal systems in the Cascade Range are older, and parts of Mount Rainier are much of one million years in age (Sisson and Lanphere, 1997; Sisson and others, 2001).

Crandell (1989) noted the risks in hazard zonation with a specific $H / L$ ratio where a debris avalanche "becomes directly transformed into a mudflow." Earlier, Plafker and Ericksen (1975) calculated an $H / L$ of 0.22 for the 1970 avalanches from Nevados Huascarán but noted that, because of the transformation to debris flow, it was virtually impossible to derive a meaningful figure. In the area of maximum casualties in and near Yungay, the 1970 flow consisted of a macroturbulent front with ballistically launched boulders that was immediately followed by wet, muddy debris that produced the peak trimline. The nonseismogenic flow from the same location in 1962 that took 4,000 lives in Ranrahirca, near Yungay, was also a debris flow (Plafker and Ericksen, 1975). In both cases, transformation to debris flow was facilitated by a high proportion of snow and ice as well as by cataclasis of bedrock during flow. Earlier yet, Heim (1932) suggested that the mobility of similar large flows could be the result of fluidization due to interstitial mud, and Hsü (1975) noted that the "presence of interstitial watery mud might also be responsible for the mobility for some sturzstroms such as the Huascarán event; muddy sturzstroms might...change into less rapidly advancing mudflows."

\section{DEBRIS FLOWS FROM LANDSLIDES AND VOLCANO COLLAPSES- EXTRAPOLATING CASE HISTORIES}

Although runout mobility can be very high, as well as unpredictably variable, is it possible for case histories of past volcanic collapses to be a useful guide to identifying areas at future risk?

Simply recognizing the potential for extreme mobility is a significant first step. For example, before May 18, 1980 at Mount St Helens, the possibility of sector collapse was known, but the potential mobility of its runout was not recognized. Had the 1980 runout been as mobile as a Holocene collapse of similar volume at Mount Rainier (the Osceola Mudflow), catastrophic flow would have extended to the Columbia River. Flow would then have proceeded upstream, approaching the metropolis of Portland, Oregon, and downstream to the Pacific Ocean, inundating portions of large communities in Oregon and Washington in both directions. On May 18, 1980 , there would have been little or no warning of the approaching flow. Had a radioed or telephoned event warning (flow is occurring) been received, emergency response and evacuation plans for a volcanic debris flow did not then exist in any of those communities. This huge volcanic disaster did not occur because the debris avalanche did not directly transform to a cohesive lahar, for reasons not precisely known but on which we speculate above. In retrospect, based on the frequency of direct flow transformations we report here, if recognized before May 18, 1980, the catastrophic scenario could have been seen as the more likely outcome.

Secondly, the size and frequency of past flows from different volcanoes, and from different watersheds of a single volcano, can concentrate mitigation strategies, otherwise possibly diffuse, where the risk is highest. Flank collapses large enough to reach communities have been 
common at some Cascade Range volcanoes but not others, and have tended to recur in specific watersheds. For example, at Mount Baker, Washington, numerous debris-flow-producing collapses have occurred from only the southeast half of the edifice during the Holocene (Scott and others, 2000). Viewing the Cascade Range volcanoes collectively at any time in the later Holocene, future risk has been accurately indicated by the earlier Holocene history. Only the 1980 lateral blast at Mount St. Helens is without an unequivocal earlier parallel of comparable magnitude in the Cascade Range.

In the following sections, we discuss why, in extrapolating from the past to the future, and from past flows of a certain size and type to potential future flows, significant variation can occur.

(1) Bulking. Debris flow volumes vary with the amount of material incorporated during flow (the process known as bulking). Consequently, total volume may increase downstream as material is added to the flow, yet the peak discharge will decline as the flow wave elongates but is reduced in amplitude. The process is well documented for noncohesive debris flows, in that they commonly form by the entrainment of sediment in water floods (Pierson and Scott, 1985; Scott, 1988a and 1988b, and Pierson and Waitt, 1997). It is less well known for cohesive debris flows. Examples, however, include the Electron Mudflow at Mount Rainier, which consisted of over 80 percent introduced material (8-32 $\mathrm{mm}$ fraction) where it reached the lowlands, $50 \mathrm{~km}$ downstream (Scott and others, 1995). The Osceola Mudflow consisted of 50 percent introduced clasts in the coarse or dispersed phase at the same distance (Vallance and Scott, 1997). Similarly, bulking of 30 percent of this size fraction in the Río Páez flow had occurred at Paicol, $91.4 \mathrm{~km}$ downstream. The best documented example is the enlargement in total volume of the 1998 collapse from Casita volcano in Nicaragua, relative to the volume of the derivative debris flow, by at least several fold (Scott, 2000).
(2) Gradations in flow behavior. Variation in the mobility of flows transformed from landslides reflects a spectrum of behaviors between the grain flow of a debris avalanche sensu stricto and the slurry of a debris flow. Although high mobility is common at Cascade Range volcanoes, intermediate degrees of mobility are emerging from detailed studies of several paleoflows. A noteworthy example is the behavior of the Round Pass Mudflow in two major tributaries of Mount Rainier (table 3); more than 90 percent of the deposits occur within $40 \mathrm{~km}$ of the volcano. In contrast, more than 90 percent of the deposits of the Electron Mudflow occur more than $40 \mathrm{~km}$ from the volcano. Both flows originated from the same sector of Mount Rainier.

(3) Changes in flood plain roughness. Future flows will travel faster and farther than did their ancient analogs of comparable volumes in temperate climates. For example, ancient flows at Mount Rainier and other Cascade Range volcanoes plowed through dense, mature forests of conifers up to $2 \mathrm{~m}$ in diameter. However, modern flood plains have been widely cleared for agriculture and development, with consequent large decreases in hydraulic roughness. Most of the modern structures built on the ancient flow deposits, relative to the likely impact forces of debris flows 10 or more $\mathrm{m}$ in depth, would provide trivial resistance to future flows. A recurrence of the Electron Mudflow, for example, could inundate a 40 percent greater area than did the prehistoric flow (Scott and Vallance, 1995). Flowrouting models applied to lahars (Costa, 1997) can address this problem where the changes in the energy-loss coefficients can be estimated.

(4) Scale effects. Large volcanic debris avalanches are more mobile than small ones, as defined by lower $H / L$ ratios (see discussion in Siebert, 1996). Near the upper end of the size range, a debris avalanche from Nevado del Colima in Mexico with a minimum volume of $22-33 \mathrm{~km}^{3}$ traveled $120 \mathrm{~km}$ to enter the ocean over a $>10-\mathrm{km}$-wide front 
with an $H / L$ of $<0.04$ (Stoopes and Sheridan,1992). The volumes of the flows in table 3 that reached the Pacific Ocean (50-60 to $>125 \mathrm{~km}$ ) vary from 0.1 to 3.8 $\mathrm{km}^{3}$. The Electron Mudflow, volume of $0.23 \mathrm{~km}^{3}$, and the Osceola Mudflow, volume of $3.8 \mathrm{~km}^{3}$, are flows of significantly different size that traveled from Rainier and inundated broad downstream valleys, wall-to-wall to or approaching Puget Sound. Although deposits of the Electron Mudflow have been verified only to within $15 \mathrm{~km}$ of the present shoreline, the lower modern floodplain roughness assures that a recurrence of the flow would extend to Puget Sound.

The effects of scale and source-material are difficult to separate, and they are illustrated at Cascade Range volcanoes by differences in the behavior of historic failed volumes of less than $0.1 \mathrm{~km}^{3}$ (tables 3 and 4). The A.D. 1890-1891 debris avalanche at Mount Baker, beginning as a failure of little altered material and the second largest of the historic flows at $0.020 \mathrm{~km}^{3}$, had mainly transformed to a cohesive debris flow by $8.5 \mathrm{~km}$ from source but traveled little more than $2 \mathrm{~km}$ farther (table 4). The third largest, the A.D. 1963, 0.011-km debris avalanche at Mount Rainier, was composed of moderately altered material and was probably approaching transformation when it stopped by ramping up a Neoglacial terminal moraine (table 4). It then yielded a small secondary debris flow. These examples contrast, however, with the largest of the historic flows at 0.03 to $0.04 \mathrm{~km}^{3}$, the A.D. 1843 Morovitz Creek lahar (table 3), that was derived from an intensely altered and probably saturated part of the Mount Baker edifice and immediately transformed to a cohesive debris flow.

(5) Varying collapse potential between sectors of an edifice. Mount Baker, as noted above, is an example of a volcano where numerous Holocene collapses have occurred from only the southeast half of the volcano (including all the examples cited in tables 3 and 4). This past history is clear evidence of the future hazard potential from the same flank of the volcano.

(6) Volume of a volcanic landslide as an "input hydrograph." Early predictions of inundation areas at risk of lahars at Cascade Range volcanoes included the approach of routing a meltwater surge that would transform to a noncohesive lahar as it entrained sediment. An "input hydrograph" was predicted from modeling of melt rates and volumes upon contact of hot volcanic products with snow and ice. Over time, with the experience of other case histories such as Nevado del Ruiz (Pierson and others, 1990) and with experimental study (Walder, 1997, 2000a, and 2000b), the interactions of hot volcanic products and snow and ice were recognized as complexly dynamic and difficult to forecast. No input hydrograph could be assumed.

With recognition that dangerous lahars also begin as landslides, forecasting inundation areas became a more logical approach. The "input hydrograph"- - volumes of unstable material - can be routed and their inundation areas extrapolated. Iverson and others (1998) make the important generalization that the area inundated by a debris flow (with no bulking) is about 20 times that of a rock avalanche (cf., debris avalanche senso stricto in this discussion) of initially similar volume. This minimal degree of potential mobility must be considered in every prediction of the future behavior of landslide runouts (table 6). The factors described above-flow bulking, differences in mobility, and changes in flood plain roughness - create uncertainty but they probably can be reasonably estimated from case histories at a volcanic scale. The extrapolation of any single predicted collapse volume is subject to considerable uncertainty because of these factors as well as the lack of any guarantee that a larger-than-predicted volume will not fail and thus that a larger area may be inundated. 
Potential debris flow inundation can be portrayed by extrapolating a range of lahar deposit volumes (LAHARZ program; Schilling, 1998), energy cone models (Sheridan and Macias, 1995; Sheridan and Kover, 1996), or simply known inundation areas. The LAHARZ program of Schilling (1998) is especially realistic because it incorporates case histories that include flows known to have enlarged by bulkingincluding those from Mount Rainier (Scott and others, 1995). GIS-based approaches (Schilling, 1998; Schilling and Iverson, 1998) are particularly useful where flow pathways are not well-defined on the ground, and where flows may spread widely as on the subtle topography of the ring plains of New Zealand volcanoes and the analogous faldas (skirts) of Nicaraguan volcanoes. Topographic control sufficient to construct accurate digital elevation models (DEM's) is a prerequisite. Regardless of the range or the size of the case histories extrapolated, all of these approaches will indicate relative risk and thus will be a valuable guide to planning future land-use. None, however, can be used to define the absolute downstream limits of flow in debris flow pathways.

\section{FORENSIC DOCUMENTATION OF FLOW PATHWAYS-PAST EVENTS AND FUTURE PREDICTIONS}

\author{
Each of the catastrophic flows discussed in \\ this report was foreshadowed by historic or \\ prehistoric analogs extending to and beyond the \\ sites of the modern tragedies.
}

With the tragedy at Nevado del Ruiz in 1985, our paradigm of concern for human welfare in volcanic terrains shifted emphasis from responding to disasters, to anticipating them over the longer term. The first stage in anticipating and therefore in preventing volcanic catastrophes is the recognition of past hazards and the areas they affected (Voight, 1996). Past flows are recognized, if not from history or oral tradition, from the paleohydrologic, sedimentologic, and strati- graphic characteristics of deposits that can provide incontrovertible evidence of future risk. Integrating paleoeruptive and paleohydrologic analyses provides a conservative analysis of past hazards and thus of future risk. Stratigraphic sequences can yield minimum flow frequency, minimum deposit volumes, reconstructed cross sections, and estimated velocities, from which we can usefully estimate flow magnitude, both as volumes and peak discharges. The risk factors discussed here can be components of regional surveys to reveal high-risk areas and to focus drainage-specific analyses, the time and expense of which are readily justified for large populations. Here we emphasize the forensic documentation of past events-evidence that will testify unequivocally that cities downstream from volcanoes and in the river valleys of volcanic terrains are constructed on the deposits of past debris flows and thus are located in the path of future flows.

\section{Hazard Assessments}

Hazard assessments and hazard-zonation maps are vital to planning effective mitigation (Crandell and others, 1979; Miller, 1988).

Recent examples include a series prepared by the U.S. Geological Survey that focuses on individual volcanoes of the Cascade Range (for example, that for Mount Rainier by Hoblitt and others, 1998). Hazard assessments can distinguish between those volcano hazards that will be associated with an eruption and those that may occur either without precursory activity or early in a volcanic crisis. They can also integrate volcanic and hydrologic flow hazards. Eruption planning may be based on a "maximum expected eruption," which can be a single historic or prehistoric eruption, or can represent a composite of hazardous areas based on intervals of volcanic history. Hydrologic planning commonly incorporates a "maximum probable flood" with a recurrence interval of 500 years that is estimated from flow records and regional approaches to flood frequency. The frequency of cohesive debris flows of collapse origin can be treated in this manner-the approach of Scott and others (1995) for Mount Rainier. 
Hazard assessments can also distinguish a category of so-called "worst-case" (or "maximum," "maximum credible," or "maximum possible") flows-those flows with risks that are unacceptable at even small, poorly defined probabilities - known as low-probability, highconsequence phenomena. The Osceola Mudflow at Mount Rainier is an example of a "maximum" cohesive debris flow (Vallance and Scott, 1997), and is so treated in the most recent hazard assessment (Hoblitt and others, 1998). This dichotomy permits contingency planning at two levels: (1) in the flow pathways that are of primary concern for evacuation planning linked with both the "maximum expected eruption," and the long-term frequency of debris flows regardless of origin and triggering mechanism, and (2) in the pathways that are potentially subject only to the most catastrophic flows but which still should be excluded as the sites of so-called "critical" facilities such as hospitals and emergency response centers.

There is no single recipe for flow hazard assessment. However, where large populations are at long-term risk, the only effective approach that will justify mitigation strategies such as land-use restrictions and warning systems will probably be evidence of past flow magnitude and frequency that is forensically documented with the approaches that we describe herein. Future hazard assessments may apply the following recent or developing approaches, especially where time is of the essence in cases of newly detected volcanic unrest:

(1) Delineating the potential areas of inundation from one or a series of flows, each with an estimated deposit volume that is portrayed in accordance with the behaviors represented by a group of case histories (LAHARZ PROGRAM; Schilling, 1998; as described above).

(2) Other projections of potential flow pathways, as with the approaches of Sheridan and Macias (1995) and Sheridan and Kovar (1996).

(3) Hydraulic modeling calibrated with paleohydrologic case histories (Costa, 1997; cf., Pareschi, 1996).
(4) Predicting flow travel times based on the velocities from a large data set of case histories at other volcanoes (Pierson, 1998), as well as the velocities reported here for seismogenic flows (table 2).

(5) Measuring rock strength of the edifice (Watters and Delahut, 1995; Bowman and others, 1998; and Watters and others, 2000).

(6) Quantifying slope stability by analyzing DEM's (Reid and others, 1999).

(7) Mapping or remotely sensing edifice structure (Sisson, 1995; Sisson and Lanphere, 1997; Sisson and others, 2001) and hydrothermal alteration (Crowley and Zimbelman, 1997; Finn and others, 1998; Finn, 2000) to define areas of potential failure.

\section{Risk Anaylsis-Example of Mount Rainier}

Risk analysis is a generic term for methods that support decisionmaking by quantifying consequences and their probabilities of occurrence (Committee on Techniques for Estimating Probabilities of Extreme Floods, 1988). In the case of eruption hazards at volcanoes, a hazard assessment may involve an analysis of eruption frequency to arrive at probability. The risk of a volcanic hazard like a debris flow of collapse origin can be treated like a randomly occurring, hydrometeorological event. Recurrence of huge sector collapses obviously involves a repose period during which the edifice is reconstructed; recurrences of the smaller failures we describe as flank collapses do not. The relation proposed by Fournier d'Albe (1979) can be applied to flows (Scott and others, 1995):

$$
\begin{aligned}
& \text { FLOW RISK = flow magnitude (volume, } \\
& \mathrm{x} \text { flow frequency (probability) } \\
& \mathrm{x} \text { values at risk (populations) } \\
& \mathrm{x} \text { vulnerability (high without } \\
& \text { event or pre-event warning) }
\end{aligned}
$$

The term for values at risk may be separated from the rest of the analysis, thereby permitting periodic recalculation of the risk in monetary terms in response to new information. 
Legally defensible estimates of flow probability were derived from the paleohydrologic and paleoeruptive record at Mount Rainier (Scott and others, 1992 and 1995). Consequently, a large-scale atlas portrayal (Scott and Vallance, 1995) of the resulting map became the basis for codified land-use restrictions in the unincorporated parts of downstream flow pathways. Acceptance by the planners involved in applying the growth restrictions, and the defense of those mandates by the U.S. Geological Survey in a legal challenge to the planning agency, were facilitated by presenting risk in the readily understood terms of flood hydrology and floodrisk analysis.

Public support of the growth restrictions in the valleys downstream from Rainier is facilitated by the statistical comparison of volcanic flow risk with the risk of structure fire. This strategy was modeled on that used by the Federal Environmental Management Agency (FEMA) to publicize the risk of meteorologic floods and thus encourage the purchase of flood insurance. In the flow pathways mapped downstream from Mount Rainier (fig. 19), the risk to an individual structure from damage by a debris flow of collapse origin is comparable to the risk from damage by fire (cf., comparison of flood-inundation frequency and fire incidence by FEMA, written commun, 1997; Scott and others, 1998).

The fire-risk analogy can also be effective in maintaining the long-term support necessary not only for limiting populations in lahar pathways, but for implementing a warning system and for planning evacuations and other emergency responses. Continued support of these measures over the long period that is probably necessary before they prove their worth can effectively be likened to, although fire has not occurred, renewing fire insurance and replacing the batteries in smoke detectors.

\section{MITIGATION STRATEGIES}

\section{Land-use Planning}

The obvious response to a flow hazard that presents either continuous risk or risk without a clear potential for effective pre-event warning is the maximum practical avoidance by limiting population densities with land-use planning. A timely case for limiting long-term exposure to volcanic risk was made by Crandell and others (1975) before the 1980 eruption of Mount St. Helens:

"[Once] dwelling places and other land uses are established, they tend to persist for centuries or even millennia. Major changes in long-established land-use patterns, which become necessary to protect lives or property, can themselves be economically disastrous and socially disruptive; therefore, potential volcanic hazards should be considered while choices can still be made with respect to future land use, even though eruptions may still be decades away."

Evacuating populations from flow pathways is an economically and socially disruptive procedure that is difficult to initiate, more difficult to maintain, and extremely difficult to repeat. Precursory volcanic activity, the potential consequences of which justify an evacuation, commonly will wax and wane; the risk may be prolonged or the activity may subside without an eruption. The public may perceive either situation as a false alarm, and continued evacuation or a second evacuation with renewed activity may be only partially successful. Eruptive activity, once begun, may also ebb and flow. Most eruption fatalities occur weeks (35 percent) to months (24 percent) after the initial activity (Simkin and others, 1998). The political consequences of a false alarm are known to have rendered evacuation so difficult that it appeared to have been possible only if the danger could be "guaranteed" (Voight, 1996).

Evacuation of flow pathways below Mount Rainier will be difficult, because of the size of the populations at risk (tens of thousands) and their distances from the volcano (over $50 \mathrm{~km}$ ). Sustained evacuation will disable the local economy, and possibly the regional economy as well. The chief of emergency planning for the area that includes most of the valleys downstream from Mount Rainier recognizes what is widely recognized as the "false alarm problem" in saying, "I can only evacuate the flow pathways once." (S.C. Bailey, personal commun., 1999). 


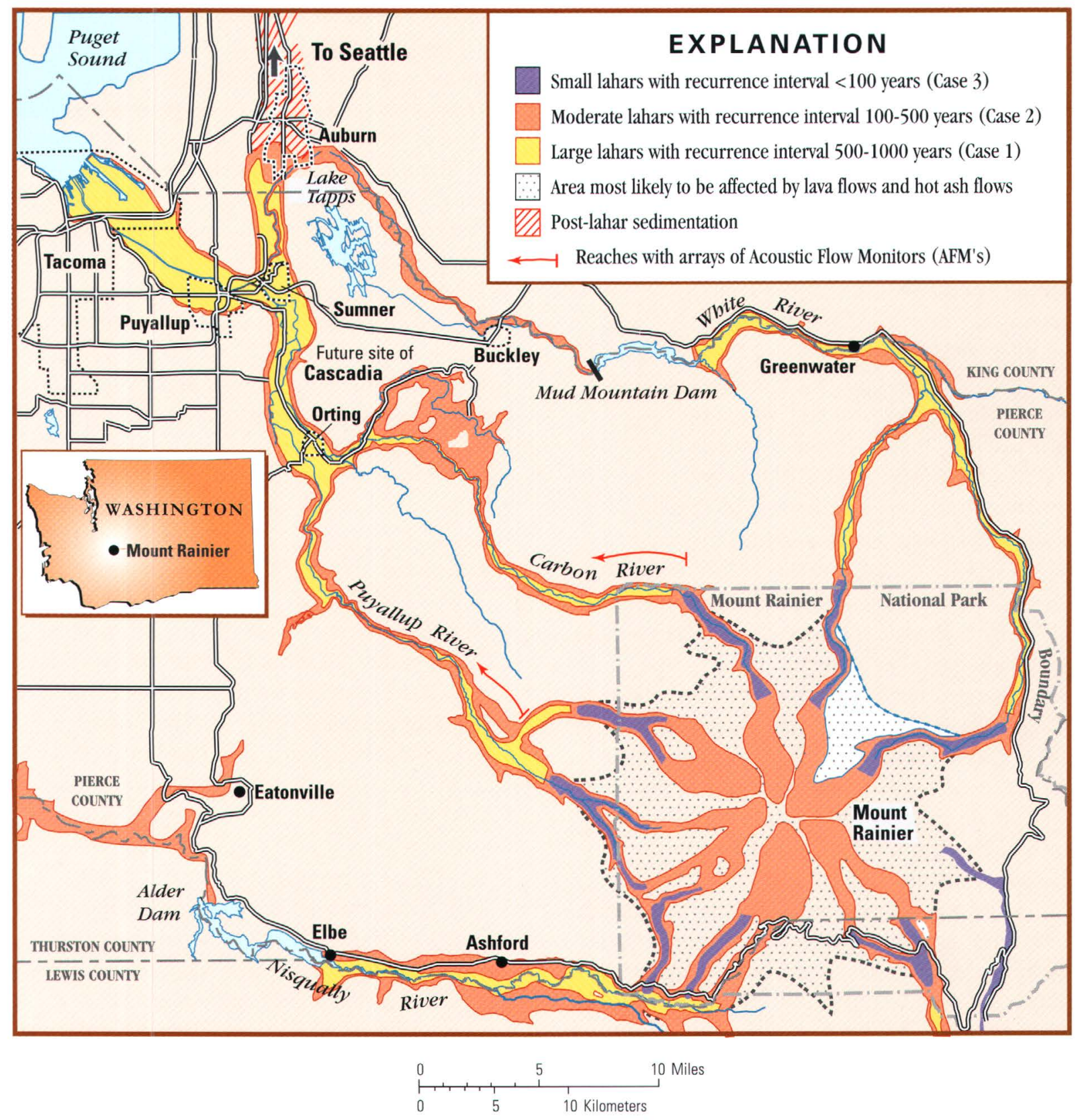

Figure 19. Volcanic flow hazards at Mount Rainier, Washington, showing the main population centers and downstream inundation areas for the three case histories described in the explanation. Note reduced inundation area downstream of Mud Mountain Dam, as discussed in text. Modified from Scott and Vallance (1995) and Hoblitt and others (1998). 
The net result of all considerations, and ultimately of the "false alarm problem," is for land-use planning to become the most logical as well as the only fail-safe response to the risks of debris cohesive flows of collapse origin. This is true regardless of how the initiating collapses are triggered. From the broadest perspective-one also incorporating the risks of large syneruptive and noncohesive debris flows for which pre-event warning is possible-land-use planning is likewise the most logical and the only fail-safe response. In reference to Crandell's comments, above, the ultimate basis for this conclusion is the 1985 destruction of Armero. That city was constructed on a site overrun by debris flows in 1595 and 1845 (see Voight, 1996), and it remained unevacuated - at the foot of an active volcano, in a lahar pathway defined by historic inundations - for many months before its destruction.

Many high-risk volcanoes exist in areas that are already densely populated areas, so that landuse planning is not an effective option (Tilling and Eichelberger, 1998). Where local populations are still at levels for which evacuation is possible, as in many of the Western Hemisphere examples discussed here, minimizing their numbers by legal mandate is a clear option. An example of unwise siting was the modern (1970's) location of two new towns in Nicaragua, El Porvenir and Rolando Rodriguez, both obliterated by the debris flow beginning as a flank collapse in 1998 (Scott, 2000). However, any volcanic hazard assessments of that era would have shown the town locations to be safe, because the risk of unanticipated lahars from inactive volcanoes was unrecognized. An example of wise planning is the siting of the future city of Cascadia, to be located near Mount Rainier yet on high ground between the Carbon and White Rivers (fig. 19).

\section{Instrumental Event Warnings to Lowland Residents in Volcanic Terrains}

Municipalities that are still at levels for which rapid evacuation is possible may elect to continue to increase their populations and rely on event warnings-notification that a flow may have begun or is on its way. The ground motion generated by debris flows is predominantly in the frequency range of 30 to $80 \mathrm{~Hz}$, compared to $6 \mathrm{~Hz}$ for earthquakes and volcanic tremor (R.G. LaHusen, 1998, and personal commun., 1998). This frequency can specifically be detected by Acoustic Flow Monitors (AFM's), solar-powered, microprocessor-based field computers linked to exploration-model geophones (LaHusen, 1998). Their upstream installation and telemetered linkage to downstream sirens can provide valuable detection and warnings of flows. The cities of Orting, Sumner, and Puyallup at Mount Rainier (fig. 19) are examples of large populations a significant distance from a volcano where an AFM system can prevent disaster, and could have done so for similarly situated Armero at Nevado del Ruiz. An AFM system will, of course, detect moving debris flows of any origin.

An AFM network exists at Cotopaxi Volcano in Ecuador; detection systems are also being installed both at Nevado del Ruiz and along the Río Páez downstream from Nevado del Huila; and a fully automated pilot system for both detection and warning is installed in two major drainages of Mount Rainier (fig. 19). An array of 5 AFM's is installed in each of the Carbon and Puyallup Rivers. In the case of the community of Orting (fig. 19; population presently about 6,000), 50 channel kilometers from Mount Rainier, sufficient warning time-most of one hour for a flow to travel from the array-exists for a siren alert and evacuation after AFMconfirmed flow detection. Nevertheless, development in flow pathways below Mount Rainier and elsewhere should not continue on the basis that any system can be fail-safe. Reliance on a warning system and rapid evacuation after a flow has begun is a policy that may tempt development into fatal ground if populations surpass levels for which evacuation cannot be assured.

In addition, the seismic signal of the flank collapse itself can potentially be distinguished from that of an earthquake as detected by the regional seismic network. This difference may be the future key to the earliest possible alert (see Norris, 1994; S.D. Malone, personal commun., 1998), whether the collapse is triggered by an earthquake or not. 


\section{Educating Residents of Flow Hazard Zones to Recognize the Possible Initiation or the Actual Approach of a Large Debris Flow}

\section{Recognition of seismic shock as a possible flow trigger}

In 5 case histories of seismogenic flows from volcanic terrain, or terrain in a volcanic zone (table 8), the time intervals between the initiating earthquake and the arrival of a catastrophic flow in populated areas were tragically short, most between 2 and about 10 minutes. The majority of the resulting 20,000 deaths (18,000 in Yungay, Peru) occurred so close to the flow origin, and velocities of the flow fronts were so high (see tables 2 and 9), that instrumental detection and confirmation of the moving flow and a siren warning could not have been very effective. The best chance for many of those in the proximal areas-from the base of failed slopes or the edifice flank to a distance of several kilometerswas to go to high ground with the initial seismic shock.

\section{Recognition of the acoustic signal of an approaching flow}

Beyond this proximal zone, however, the acoustic signal of the moving flow could have been an effective warning. Valley residents could, in effect, have been their own AFM's. Communities in Mexico and Colombia were destroyed by seismogenic flows that were clearly heard and felt as much as 5 minutes, from a distance of about $5 \mathrm{~km}$, before they arrived (table 9). Few people fled because the recurrent response in these cases was only that a second earthquake had begun. The initial warning of the moving flow was probably a rumbling or roaring noise (a "prolonged muffled thunderclap" in

Table 8: Historic seismogenic flows in the western hemisphere and times of arrival of flow fronts following earthquakes at the sites of most casualties.

Information sources: Mexico (Camacho, 1922; Flores, 1922); Chile (Wright and Mella, 1963): Peru (Plafker and Ericksen, 1975); Ecuador (Schuster and others, 1996); Colombia (this report)

[km, kilometers; min, minutes]

\begin{tabular}{|c|c|c|c|c|}
\hline Date & Fatalities & Location & $\begin{array}{l}\text { Distance from } \\
\text { source }(\mathrm{km})\end{array}$ & $\begin{array}{l}\text { Time of arrival in } \\
\text { main populated } \\
\text { area after } \\
\text { earthquake (min) }\end{array}$ \\
\hline 1920 & $>600$ & Barranca Grande, Mexico & 15 & $10 *$ \\
\hline 1960 & $>125$ & Lake Rupanco, Chile & $<4$ & $<2$ \\
\hline 1970 & $>18,000$ & Yungay, Peru** & $14-15$ & $3^{\#}$ \\
\hline 1987 & $1,000^{\# \#}$ & $\begin{array}{l}\text { Towns on Ríos Due, Coca, } \\
\text { and Salado, Ecuador }\end{array}$ & $\sim 2-20$ & Probably $\sim 2-25$ \\
\hline \multirow[t]{5}{*}{1994} & $600-1,000$ & Towns on Río Páez,Colombia: & & \\
\hline & & Dublín & 1 & 0.5 \\
\hline & & Irlanda & 4 & $2-3$ \\
\hline & & Tóez & 9 & $6-9 *$ \\
\hline & & Belalcázar & 30 & $20-30^{*}$ \\
\hline
\end{tabular}

\footnotetext{
* Flow heard or felt about five minutes before arrival

** Source was granitoid bedrock in steepland in volcanic zone

\# Flow heard when near point of origin from $14 \mathrm{~km}$ away, about 2.3 minutes before arrival, corrected for speed of sound

\#\# Includes deaths from slides and floods (small proportion from channelized debris flows)
} 
Table 9: Reports of noise and ground shaking associated with the approach of large debris flows. [m, meters; km, kilometers; min, minutes; $\mathrm{m} / \mathrm{s}$, meters per second]

\begin{tabular}{|c|c|c|c|c|c|c|}
\hline $\begin{array}{l}\text { Date and } \\
\text { location } \\
\text { of flow }\end{array}$ & $\begin{array}{l}\text { Noise [distance or } \\
\text { time before arrival } \\
\text { of flow front (or } \\
\text { distance away } \\
\text { from channel)] }\end{array}$ & $\begin{array}{l}\text { Ground shaking } \\
\text { [distance or time } \\
\text { before arrival of } \\
\text { flow front (or } \\
\text { distance away } \\
\text { from channel)] }\end{array}$ & $\begin{array}{l}\text { Depth } \\
(\mathrm{m})\end{array}$ & $\begin{array}{l}\text { Flow } \\
\text { velocity* } \\
\text { (km/min; } \\
\mathrm{m} / \mathrm{s})\end{array}$ & $\begin{array}{l}\text { Discharge } \\
\left(\mathrm{m}^{3} / \mathrm{s}\right)\end{array}$ & References \\
\hline \multicolumn{7}{|c|}{ COHESIVE FLOWS (Seismogenic)) } \\
\hline $\begin{array}{l}1-3-20 \\
\text { Mexico }\end{array}$ & $\begin{array}{l}\text { "Prolonged thunder } \\
\text { clap" } 5 \mathrm{~km} ; 5 \text { minutes }\end{array}$ & $\begin{array}{l}\text { Not reported but } \\
\text { probably similar to } \\
1994 \text { flow in Colombia, } \\
\text { below }\end{array}$ & $30-65$ & $\begin{array}{l}>1 \mathrm{~km} / \mathrm{min} \\
>17 \mathrm{~m} / \mathrm{s}\end{array}$ & $>100,000$ & $\begin{array}{l}\text { Camacho, } 1922 ; \\
\text { this report }\end{array}$ \\
\hline $\begin{array}{l}5-31-70 \\
\text { Peru }\end{array}$ & $\begin{array}{l}\text { Avalanche fall heard } \\
\text { as "explosion" } \\
14 \mathrm{~km} ; 2.3 \text { minutes** }\end{array}$ & $\begin{array}{l}\text { Not reported but } \\
\text { probably more intense } \\
\text { than } 1962 \text { flow, below }\end{array}$ & 80 & $\begin{array}{c}4.6 \mathrm{~km} / \mathrm{min} \\
78 \mathrm{~m} / \mathrm{s}\end{array}$ & $>100,000$ & $\begin{array}{l}\text { Plafker and Erickson, } \\
1975\end{array}$ \\
\hline $\begin{array}{l}\text { 6-6-94 } \\
\text { Colombia }\end{array}$ & $\begin{array}{l}\text { Mountains "roaring" } \\
5 \mathrm{~km} ; 5 \text { minutes }\end{array}$ & $\begin{array}{l}\text { Flow thought to be an } \\
\text { an aftershock; possibly } \\
5 \mathrm{~km} ; 5 \mathrm{~min}\end{array}$ & $30-40$ & $\begin{array}{l}1.0-1.5 \\
\mathrm{~km} / \mathrm{min} \\
17-25 \mathrm{~m} / \mathrm{s}\end{array}$ & $>100,000$ & This report \\
\hline \multicolumn{7}{|c|}{ COHESIVE FLOWS (Nonseismogenic) } \\
\hline $\begin{array}{l}1-10-62^{\#} \\
\text { Peru }\end{array}$ & $\begin{array}{l}\text { "Roar like that of } \\
10,000 \text { wild beasts;" } \\
\text { about } 14 \mathrm{~km} \text {; } \\
\sim 4 \text { minutes** }\end{array}$ & $\begin{array}{l}\text { "Rumble," "like an } \\
\text { earthquake;" } \\
\text { possibly about } 14 \mathrm{~km} \text {; } \\
\text {-4 min }\end{array}$ & $>20$ & $\begin{array}{c}2.8 \mathrm{~km} / \mathrm{min} \\
47 \mathrm{~m} / \mathrm{s}\end{array}$ & $>100,000$ & $\begin{array}{l}\text { McDowell and Fletcher, } \\
\text { 1962; Morales, 1996; } \\
\text { Plafker and Ericksen, } \\
1975\end{array}$ \\
\hline $\begin{array}{l}10-30-98 \\
\text { Casita }\end{array}$ & $\begin{array}{l}\text { "Helicopters" or } \\
\text { "thunder;" } \\
2.5-3.0 \text { minutes }\end{array}$ & $\begin{array}{l}\text { "Like earthquakes;" } \\
\text { unknown but probably } \\
<2 \text { minutes }\end{array}$ & $\begin{array}{l}>20 \\
\text { on flank; } \\
3-6 \text { at } \\
\text { townsites }\end{array}$ & $\begin{array}{l}>1.5 \mathrm{~km} / \mathrm{min} \\
>25 \mathrm{~m} / \mathrm{s}\end{array}$ & $\begin{array}{l}110,000 \\
\text { at townsites }\end{array}$ & $\begin{array}{l}\text { Sheridan and others, } \\
\text { 1998; Barreto, 1998; } \\
\text { Scott, } 2000\end{array}$ \\
\hline \multicolumn{7}{|c|}{ NONCOHESIVE FLOWS } \\
\hline $\begin{array}{l}11-13-85 \\
\text { Nevado } \\
\text { del Ruiz }\end{array}$ & $\begin{array}{l}\text { "Roar," but noise } \\
\text { damped by that of } \\
\text { concurrent storms }\end{array}$ & $\begin{array}{l}\text { "Incredible" ground } \\
\text { shaking; unknown } \\
\text { but probably several } \\
\text { minutes }\end{array}$ & $10-30$ & $8-15 \mathrm{~m} / \mathrm{s}$ & $\begin{array}{c}10,000- \\
48,000\end{array}$ & $\begin{array}{l}\text { Voight,1988; Pierson } \\
\text { and others, 1990; } \\
\text { J.P. Lockwood, per- } \\
\text { sonal commun., } 1998\end{array}$ \\
\hline $\begin{array}{l}10-2-47 \\
\text { Mount } \\
\text { Rainier }\end{array}$ & $\begin{array}{l}\text { Probably several } \\
\text { minutes }\end{array}$ & $\begin{array}{l}\text { "Rumbling and earth- } \\
\text { shaking that was } \\
\text { awesome in its } \\
\text { magnitude" }\end{array}$ & $3-15$ & $\sim 15 \mathrm{~m} / \mathrm{s}$ & $\sim 600$ & $\begin{array}{l}\text { Grater, 1948; Nelson, } \\
\text { 1987; Scott and others, } \\
1995\end{array}$ \\
\hline $\begin{array}{l}\text { 6-29-88 } \\
\text { Mount } \\
\text { Rainier }\end{array}$ & $\begin{array}{l}\text { "Roaring noise" } 2 \\
\text { minutes downhill } \\
\text { walk from channel, } \\
\sim 250 \mathrm{~m} ; \sim 30 \text { seconds }\end{array}$ & $\begin{array}{l}\text { "Ground rumbling } \\
\text { underfoot;" } \sim 250 \mathrm{~m} \text {; } \\
\sim 30 \text { seconds }\end{array}$ & 8 & $8 \mathrm{~m} / \mathrm{s} \# \#$ & $\sim 2,000$ & $\begin{array}{l}\text { J.S. Fielding, written } \\
\text { commun., } 1988\end{array}$ \\
\hline $\begin{array}{l}7-26-88 \\
\text { Mount } \\
\text { Rainier }\end{array}$ & $\begin{array}{l}\text { "An express train" } \\
2 \text { minutes }\end{array}$ & "Many yards" & 4 & 6-8 m/s \#\# & $\sim 2,000$ & $\begin{array}{l}\text { C.G.Parker and C.H. } \\
\text { Swift, written commun., } \\
1988\end{array}$ \\
\hline
\end{tabular}

* Based on travel times of front or, for flows at Mount Rainier, runup measurements

** Corrected for speed of sound, for 1970 flow by Plafker and Ericksen (1975)

\# Texture of flow not known but probably similar to that of 1970 flow from the same location (table 1)

\#\# Based on runup measurements of velocities of comparable flows at these locations by K.M.Scott 


\section{Descendents, descendentsoodisten}

Twenty times since the sun [first] rose... Vesuvius [has erupted] Always with huge extermination of those who hesitated...

I warn you so that it does not find you undecidled.oo

The mountain shakes itself and shakes the groundo..

If you are wise listen to the voice of this stone

Do not care about your home Do not worry about your packs Run away without delay

- Year 1632, 16 January in the reign of Philip IV Viceroy Emmanuel Fonseca

[Original ESWEV message, the Granatello Epigraph, a stone tablet inset in a street wall of Portici, Italy. Translation from Orsi and others (1998).]

Mexico in 1920; "first, we heard a sound, as if the earth and the mountains were roaring" in Colombia in 1994). In most cases the noise was accompanied by perceptible ground-shaking, and in some cases the tremor was what most impressed the survivors. In other cases, however, tremor occurred but may have been noticed after the noise of the flow. In the case of the 1998 noncohesive flow in Peru, the noise and tremor were sensed in an adjacent valley. The survivor interviews recorded by J.P. Lockwood indicate that significant ground shaking occurred prior to and during the arrival of the flow fronts in the Rìo Lagunillas at Armero and in other drainages from Nevado del Ruiz in 1985. He concluded (personal commun., 1998) that the "incredible" tremor, during which some people were unable to remain standing, could have served as a warning had its cause been known.

Potential warning time can vary greatly because of the variation in flow-front velocity (table 9) by a factor of as much as 5 . Differences in the predicted velocities of future flows can be assessed, however, on the basis of their size and the watershed and channel geometry (Pierson, 1998).

\section{Education for Self Warning and Evacuation (ESWEV)}

Education for Self Warning and Evacuation (Scott and Driedger, 1998) is simply advice to those in flow pathways to go to high ground without delay following any ground tremor perceived as an earthquake or any prolonged rumbling noise from upstream. The message creates recognition of (1) an earthquake that may have triggered seismogenic flows, (2) the seismicity possibly associated with an eruption and the possible initiation of a noncohesive lahar (as at Nevado del Ruiz in 1985, and at Ruapehu Volcano in New Zealand in 1995-1996), and (3) the approach of large debris flows regardless of their origins-whether any seismic shock (causing or caused by collapse, or both) that accompanies a collapse is felt or not. It will warn of the approach of both syneruptive debris flows of meltwater origin like those at Nevado del Ruiz and of those unassociated with eruptions or magmatic activity.

At Nevado del Ruiz, most of the 23,000 who died in 1985 would have had to travel only $75 \mathrm{~m}$ laterally (with altitude gain) from their homes to safety, and almost all who died would have had to travel less than $150 \mathrm{~m}$ (J.P. Lockwood, personal commun., 1998). At only a moderate walking speed, $75 \mathrm{~m}$ could be traversed in about 50 seconds on level ground. The accounts in table 9 establish that at least that amount of time had been available to most of the almost 50,000 who perished in 5 seismogenic flows (table 8 ) and 2 nonseismogenic examples (table 9; Huascarán in 1962 and Ruiz in 1985). 
Two case histories indicate that ESWEV can evolve as a local tradition based on past experience. We cite the reaction noted above of villagers in Peru in 1998 who, apparently aware of the signals of previous historic debris flows, climbed above the path of the flow, and did so even in an adjacent valley where no flow occurred! Okuda and others (1980, p. 147) report instances in Japan where "...sometimes people living at the lower reaches can detect the occurrence of debris flow by the vibration before the flow attacks their villages."

The potential is also underscored by the contrary, fatal reaction of villagers below Nevados Huascarán in 1962; there, "many" (Morales, 1966) or "scores" (McDowell and Fletcher, 1962) heard and felt the flow but ran, many downhill, to the central church in Ranrahirca and remained there to perish. Villagers had about 4 minutes to recognize and respond to the sound and tremor of the approaching flow (table 9). That flow was an ice-rich debris avalanche that transformed to a debris flow; it was not earthquake-triggered and, although at least one individual saw the originating avalanche, only the acoustic signals could have been generally sensed.

Table 9 includes one example-the flow beginning as a flank collapse of Volcán Casita in Nicaragua in 1998-where ESWEV could not have been more than marginally effective. Only $4-5 \mathrm{~km}$ from the base of the volcano, the result- ing debris flow spread to $1.2 \mathrm{~km}$ in width on the gentle slopes on which destroyed towns were located. There were no obvious valley-side slopes on which to have taken refuge.

The philosophy of ESWEV-encouraging individual responsibility-coincides with an emerging trend in public education about volcano hazards, endorsed by some local officials, and in some instances resonating with a distrust of authority. Bossa (1998), for example, describes the generic concept as "self protection and education to safety." The ESWEV message, in its most simplified form as designed for signs on trails and at campgrounds around Mount Rainier (fig. 20), is, "In case of earthquake or rumbling noise, go to high ground." This message can be included in public education in flow hazard zones, effectively presented with some of the anecdotal survivor accounts we relate here. It is an option wherever risk is identified, and it can be especially effective if conveyed by on-site scientists (Lockhart and others, 1998) during a developing volcanic crisis. It can be applied to unevacuated populations at the earliest level of a staged alert. The message should emphasize that only lateral movement up valley sides, as opposed to going downstream, will work. People that live, work, or attend school in potential inundation zones can be advised to plan their evacuation routes. Education in response to a volcanic crisis should distinguish debris flows, which can be sensed in time to escape their path,

\section{Lahar Hazard Zone}

In case of earthquake (or prolonged rumbling noise)

\section{Go to Higher Ground!!}

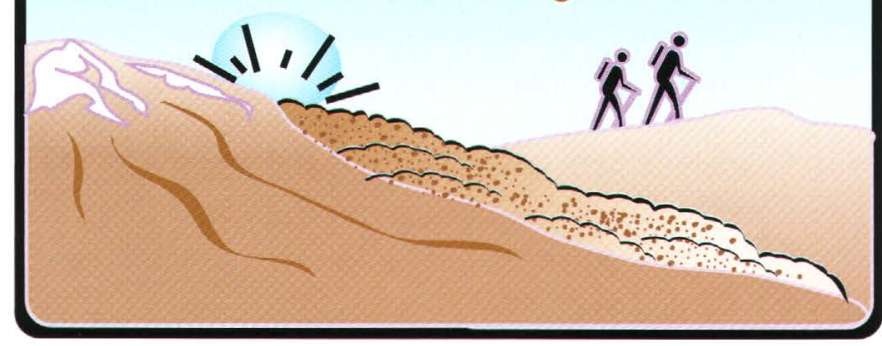

Figure 20. Version of ESWEV message posted at campgrounds and trailheads in Mount Rainier National Park, Washington. 
from pyroclastic flows, which generally cannot. Not only can pyroclastic flows be faster $(>100 \mathrm{~m} /$ s), the dilute front of the surge may travel almost silently. When one of us (Scott) accompanied Japanese scientists to the "red zone" at Mount Unzen in Japan in 1993, at that time yielding periodic dome collapses and pyroclastic flows, he was informed by experienced survivors that: "it's the ones you don't hear that can kill you." Hazard maps will show that the hazard zones for debris flows generally extend well beyond those for pyroclastic flows (fig. 19).

\section{Engineering Measures Integrating Response to Volcano and Hydrologic Hazards}

Where large populations and critical facilities already exist in potential flow pathways, "hardening" the potential targets is an option. Sediment retention structures (sediment dams) are a solution, albeit seemingly an unlikely one when no volcanic crisis impends. The expedited construction of such structures may be a logical response to precursory volcanic activity in some situations. Future reservoirs for flood control around volcanoes can be rockfill structures that will also trap significant portions of a catastrophic debris flow. Mud Mountain Dam in the White River drainage at Mount Rainier (fig. 19) is a rockfill structure that will impound much of almost any future catastrophic flow at no additional cost above that of its original function as a flood-control structure. This potential was unknown at the time of its 1948 completion. Conversely, reservoirs with the need for continuous water storage for power generation may increase downstream risks because of the potential for water displacement by a volcanic flow or, because these structures are commonly of concrete-arch design in the Cascades, their possible but unlikely failure when impacted by a flow. The potential inundation zone downstream from such structures, like Alder Dam (fig. 19), is approximated by the inundation that can result from seismic destruction of the dam. That inundation area is calculated by dam operators in the United States as required by the Federal Energy Regulatory Commission.
Risks downstream from most reservoirs cannot be reduced rapidly after an event warning or an escalation in staged alert level. Powergeneration needs normally require significant storage at all times, although levels are varied from a summer maximum to a winter minimum in order to provide storage for floods and snowmelt runoff as well. Typical reservoirs may require many days for emergency drawdown of water levels (Scott and others, 1995). In contrast, the reservoir behind Mud Mountain Dam is normally empty; in fact, since construction it has filled only once. In the future, the dam will: (1) Impound a significant part of any cohesive or noncohesive lahar, and (2) Trap a significant part of the greatly increased sediment yields that will follow an eruption.

Although the land-use planning now occurring downstream from Mount Rainier is close to the optimal possible, the population at risk will increase inexorably. The regional land-use plan does not apply within municipal boundaries, and the growth plans of cities vary greatly in their philosophy toward development and permissible densities. Thus the risk of a large cohesive debris flow will become less and less acceptable, even at probabilities smaller than those that would normally trigger a long-term planning response to rare events. A result of this trend could be structures like Mud Mountain Dam that will be designed to impound both floods and debris flows. This integrated response to volcanic and hydrologic hazards could be triggered by future events, such as a dramatic loss of life from the runout of a flank or sector collapse at Rainier or elsewhere, renewed magmatic activity at the volcano, or even a catastrophic flood like the rain-on-snow events that inundated several valleys downstream from Rainier and other Cascade Range volcanoes in the $19^{\text {th }}$ century. Those floods are not incorporated in all modern, flood-frequency-based design criteria (based mainly on $20^{\text {th }}$ century records), which could result in underestimation of potential flood magnitudes. 


\section{CONCLUSIONS}

In addition to their potential for catastrophic eruptive activity, many volcanoes must be viewed as unstable constructional landforms that form at high altitude in tectonically active zones and evolve with periodic collapse-like houses infested with termites. Volcano collapse is not only an intrusion- or eruption-related hazard, a common misconception resulting from the linkage of the largest volcanic landslides-sector collapses $\left(>1 \mathrm{~km}^{3}\right.$ )-with magmatic and phreatomagmatic activity. Smaller flank collapses may also yield highly mobile debris flows, increasing in volume by sediment entrainment (bulking), that may extend over $100 \mathrm{~km}$ to populated lowlands. The smaller the collapse volume, the less certain it will be triggered by the edifice deformation of magmatic intrusion or by eruption. Among several factors leading to increased risk from these flows is a general reduction in flood plain roughness in valleys downstream from several Cascade Range volcanoes that will cause future flows to travel faster and farther.

Findings relative to hazard assessment of volcanic debris flows include the following:

1. The most practical results will be achieved by integrating assessments of eruption hazards with assessments of the hazards that are not clearly tied to eruptions, especially the mobile debris flows transformed from flank collapses. Hazard assessments that focus on the second category will apply to selected inactive volcanic edifices.

2. The debris flow disasters cited throughout this report occurred in the pathways of readily recognized historic and, as revealed by paleohydrologic and sedimentologic analysis, prehistoric analogs. Flow history is an excellent guide to future hazard potential.

3. The most effective approach to saving lives from debris flows in large cities of volcanic terrains is the forensic documentation of flow pathways and the identification of the magnitude and frequency of previous flows as in item 2 . That evidence can testify to the need for land-use restrictions in flow pathways, and for automated event-warning systems that can successfully trigger evacuations.

4. Recognition of paleo-debris flows and paleo-debris avalanches for analysis of both frequency and inundation area will focus most effectively on the intermegaclast matrix of the deposits. The textural distinctions between cohesive and noncohesive debris flow deposits, and the consequent revelation of flow origins, are a sine qua non for probabilistic analysis of the debris flow history in volcanic terrains.

5. Multiple seismogenic failures from a volcano and the surrounding terrain mantled by volcanic flow and fall deposits can coalesce into huge waves of debris flow. This origin extends risk to major drainages in volcanic terrains that do not directly drain a stratovolcano.

6. Using limiting runout distances for potential collapse runouts (as debris avalanches) will require careful documentation of this behavior. Otherwise, the higher mobility of a debris flow must be assumed.

Specific findings relative to mitigation strategies for large volcanic debris flows include the following:

1. Land-use planning is the most practical and only fail-safe means of reducing risk in identified flow pathways regardless of flow type or triggering mechanism.

2. Permanent networks of Acoustic Flow Monitors (AFM's) may be justified to defend large populations near some volcanoes. In-place arrays may be justified by (a) the possibility of unanticipated collapses, (b) the possibility of collapse early in a magmatic episode before evacuations have been ordered, and (c) the difficulties, both of pre-event evacuation and in timely installation of an AFM network in response to a volcanic crisis.

3. ESWEV (Education for Self Warning and Evacuation) can be incorporated in public education programs, especially those in response to volcanic unrest. ESWEV is advice to residents in flow pathways to seek 
high ground upon sensing any seismic shock or rumbling noise from upstream. Numerous case histories show that fatalities can be reduced if, in effect, people are their own AFM's.

4. The integration of both volcanic and hydrologic flow risks may justify permanent structural impoundments for both sediment retention and flood control.

\section{REFERENCES CITED}

Alloway, B.V., Neall, V.E., and Vucetich, C.G., 1986, Another prehistoric debris avalanche deposit recognized from an ancestral Egmont Volcano (abs.): International Volcanological Congress, New Zealand, February 1-9, 1986, Abstracts, p. 2.

Atwater, B.F., and Hemphill-Haley, E., 1997, Recurrence intervals for great earthquakes of the past 3500 years at northeastern Willapa Bay, Washington: U.S. Geological Survey Professional Paper 1576.

Avila, G.E., Caro, P.E., Cepeda, H., Moreno, M., Torres, P., and Agudelo, A., 1995, Zonificación para uso del suelo in la cuenca del Río Páez: VII Jornadas Geotecnicas, Sociedad Colom-biana de Ingenieros y Sociedad Colombiana de Geotecnica, p. 6.79-6.102.

Bakun, W.H., and Wentworth, C.M., 1997, Estimating earthquake location and magnitude from seismic intensity data: Bulletin of the Seismological Society of America, v. 87, p. 1502--1521.

Barreto, P.E., 1998, Testimonios relacionados con los ruidos y imagenes fatales segundos antes de la tragedia, llegada repentinamente desde el volcán Casitas a las comunidades Rolando Rodriquez y El Porvenir: Managua, Nicaragua, unpublished report, $9 \mathrm{p}$.

Belousov, A.B., 1995, The Shiveluch volcanic eruption of 12 November 1964 -explosive eruption provoked by failure of the edifice: Journal of Volcanology and Geothermal Research, v. 66, p. 357-365.

Belousov, A.B., and Bogoyavlenskaya, G.E., 1988, Debris avalanche of the 1956 Bezymianny eruption: Kagoshima International Conference on Volcanoes, Proceedings, p, 460-462.
Belousova, M., Belousov, A., and Voight, B., 1998, Relationships between failure of volcanic edifice and explosive activity: case studies in Kurile-Kamchatka region, Russia (abs.): Sexta Reunion International, Volcán de Colima, Abstracts, unpaginated.

Bossa, L., 1998, The role of the local authorities in volcanic risk mitigation (abs.): International Meeting Cities on Volcanoes, Rome and Naples, "New Abstracts" addendum to Program and Abstracts, unpaginated.

Bowman, S.D., Watters, R.J., Zimbelman, D.R., and Crowley, J.K., 1998, Methodology for rock mass strength assessment and results from edifice rocks, Mount Rainier and Mount Hood, USA (abs.): Eos, v. 79, no. 45, p. 978.

Calderón, Y., Avila , G., and Ojeda, J., 1997, Estudio de amenazas y zonificación geológica de la cuenca del Río Paez, Cauca: II Simposio Latinoamericano de Deslizamientos, unpaginated separate.

Camacho, H., 1922, Efectos del temblor sobre el terrano: Chapter V, Tercera Parte, Memoria Relativa al Terremoto Mexicano del 3 de Enero de 1920: Instituto Geológico de México, Boletín 38, p. 89-94.

Carrasco-Núñez, G., and Gómez-Tuena, A., 1997, Volcanogenic sedimentation around Citlaltéptl volcano (Pico de Orizaba) and surroundings, Veracruz, México, in Aguirre-Diaz, G.J., Aranda-Gómez, J.J., Carrasco-Núñez, G., and Ferrari, L., eds., Magmatism and tectonics in central and northwestern Mexico-A selection of the 1997 IAVCEI General Assembly excursions: Mexico, D.F., Universidad Nacional Autónoma de México, Instituto de Geología, Excursion 16, p. 131-151.

Carrasco-Núñez, G., Vallance, J.W., and Rose, W.I., 1993, A voluminous avalanche-induced lahar from Citlaltépetl volcano, Mexico: Implications for hazard assessment: Journal of Volcanology and Geothermal Research, v. 59, p. 35-46.

Casadevall, T.J., Schuster, R.L., and Scott, K.M., 1994, Preliminary report on the effects of the June 6, 1994 Sismo de Páez (Páez Earthquake), Southern Colombia: U.S. Geological Survey Administrative Report, $15 \mathrm{p}$.

Committee on Techniques for Estimating Probabilities of Extreme Floods (National Research Council), 1988, Estimating probabilities of 
extreme floods, methods and recommended research: Washington, D.C., National Academy Press, $141 \mathrm{p}$.

Costa, J. E., 1984, Physical geomorphology of debris flows, in Costa, J.E., and Fleisher, P.J., eds., Developments and Applications of Geomorphology, Berlin, Springer-Verlag, p. 268--317.

_ 1997 , Hydraulic modeling for lahar hazards at Cascades volcanoes: Environmental and Engineering Geoscience, v. III, no. 1, p. 21-30.

Costa, J.E., and Schuster, R.L., 1991, Documented historical landslide dams from around the world: U.S. Geological Survey Open-File Report 91-239, 486 p.

Crandell, D.R., 1971, Postglacial lahars from Mount Rainier volcano, Washington: U.S. Geological Survey Professional Paper 677, 73 p.

_ 1987 , Deposits of pre-1980 pyroclastic flows and lahars from Mount St. Helens volcano, Washington: U.S. Geological Survey Professional Paper 1444, 91 p. , 1989, Gigantic debris avalanche of Pleistocene Age from Mount Shasta Volcano, California, and debris-avalanche hazard zonation: U.S. Geological Survey Bulletin 1861, $29 \mathrm{p}$.

Crandell, D.R., and Fahnestock, R.K., 1965, Rockfalls and avalanches from Little Tahoma Peak on Mount Rainier, Washington: U.S. Geological Survey Bulletin 1221-A, 39 p.

Crandell, D.R., Mullineaux, D.R., and Miller, C.D., 1979, Volcanic-hazard studies in the Cascade Range of the western United States, in Volcanic activity and human ecology: Academic Press, p. 195-219.

Crandell, D.R., Mullineaux, D.R., and Rubin, M., 1975, Mount St. Helens volcano: recent and future behavior: Science, v. 187, p. 438-441.

Crowley, J.K., and Zimbelman, D.R., 1997, Mapping hydrothermally altered rocks on Mount Rainier, Washington, with Airborne Visible/ Infrared Imaging Spectrometer (AVIRIS) data: Geology, v. 25, p. 559-562.

Cruden, D.M., and Varnes, D.J., 1996, Landslide types and processes, in Turner, A.K., and Schuster, R.L., eds., Landslides investigation and mitigation: Transportation Research Board,
U.S. National Research Council, Special Report 247, chap. 3, p. 36-75.

Day, S.J., 1996, Hydrothermal pore fluid pressure and the stability of porous, permeable volcanoes, in McGuire, W.J., Jones, A.P., and Neuberg, J., eds., Volcano instability on the Earth and other planets: Geological Society Special Publication n. 110, p. 77-93.

Dragovich, J.D., Pringle, P.T., Dunne, A., Parkinson, K.T., and Kahle, S.C., 1997, Quaternary geologic mapping and stratigraphy in the Deming and Kendall 7.5-minute quadrangles, Whatcom County, Washington-Implications for valley hydrostratigraphy in the foothills of the North Cascades (abs.): The $2^{\text {nd }}$ Symposium on the Hydrology of Washington State, August 25-27 1997, Evergreen State College, Olympia, Abstracts, p. 18.

Driedger, C.L., 1986, A visitor's guide to Mount Rainier glaciers: Longmire, Pacific Northwest National Parks and Forests Association, 80 p.

Driedger, C.L., and Kennard, P.M., 1986, Ice volumes on the Cascade volcanoes: Mount Rainier, Mount Hood, Three Sisters, and Mount Shasta: U.S. Geological Professional Paper $1365,28 \mathrm{p}$.

Dzurisin, D., 1998, Geodetic detection of inflating stratovolcanoes: a potential breakthrough for mitigating volcanic hazards in the $21^{\text {st }}$ century (abs.): Eos, v. 79. no. 45, p. 973.

Endo, K., Sumita, M., Machida, M., and Furuichi, M., 1989, The 1984 collapse and debris avalanche deposits of Ontake Volcano, central Japan, in Latter, J.H., ed., Volcanic hazards: Berlin, Springer-Verlag, p. 210-229.

Engebretson, D.C., Easterbrook, D.J., and Kovanen, D.J., 1996, Triggering of very large, deepseated, bedrock landslides by concentrat-ed, shallow earthquakes in the North Cascades, WA (abs.): Geological Society of America Cordilleran Section Meeeting, April 22-24, Portland, Abstracts with Programs, v. 28, no. 5, p. 64.

Escher, B.G., 1925, L'éboulement préhistorique de Tasikmalaja et le volcan Galunggung: Liedsche Geologische Mededeclingen, v. 1, p. 8-21.

Fairchild, L.H., 1987, The importance of lahar initiation processes, in Costa, J.E., and Wieczorek, G.F., eds., Debris flows/avalanches: process, recognition, and mitigation: Geological 
Society of America Reviews in Engineering Geology, v. VII, p. 51-61.

Finn, C., Deszcz-Pan, M., and Rystrom, V., 1998, Hunting for volcanic weakness at Mount Rainier with aerogeophysical data (abs.): Eos, v. 79 , no. 45 , p. 978.

Finn, C., Sisson, T.W., and Deszcz-Pan, M, 2001, Aerogeophysical measurements of collapseprone hydrothermally altered zones at Mount Rainier: Nature, v. 409, p. 600-603.

Flores, T., 1922, Efectos geológicos: Chapter IV, Primera Parte, Memoria del terremoto Mexicano del 3 de enero de 1920: Instituto Geológico de México, Boletín 38, p. 27-29.

Folk, R.L., 1980, Petrology of sedimentary rocks: Austin, Texas, Hemphill Publishing Company, $182 \mathrm{p}$.

Fournier d' Albe, E.M., 1979, Objectives of volcanic monitoring and prediction: Journal of the Geological Society of London, v. 136, p. 321-326.

Francis, P., 1993, Volcanoes, a planetary perspective: Oxford, Oxford University Press, 443 p.

Francis, P., and Self, S., 1987, Collapsing volcanoes: Scientific American, v. 256, p. 91-97.

Frank, D., Post, A., and Friedman, J.D., 1975, Recurrent geothermally induced debris avalanches on Boulder Glacier, Mount Baker, Washington: U.S. Geological Survey Journal of Research, v. 3, p. 77-87.

Fuller, R., 1980, Neoglaciation of Avalanche Gorge and the Middle Fork Nooksack River valley, Mount Baker, Washington: M.S. thesis, Western Washington University, Bellingham, Washington, $68 \mathrm{p}$.

Garwood, N.C., Janos, D.P., and Brokaw, N., 1979, Earthquake caused landslides: a major disturbance to tropical forests: Science, v. 205, p. 997-999.

Gaylord, D.R., Neall, V.E., and Palmer, A.S., 1993, The Maitahi Formation, a mid-Pleistocene volcanic debris avalanche assemblage, Taranaki, New Zealand (abs.): International Association of Volcanology and Chemistry of the Earth's Interior, General Assembly, Canberra, Abstracts.

Glicken, H., 1996, Rockslide-debris avalanche of May 18, 1980, Mount St. Helens Volcano, Washington: U.S. Geological Survey Open-File Report 96-677, 90 p.
1998, Rockslide-debris avalanche of May 18, 1980, Mount St. Helens Volcano, Washington: Geological Survey of Japan Bulletin, v. 49(2/3), p. 55-106.

Grater, R.K., 1948, A report on the Kautz Creek flood studies: National Park Service Unpublished Report [available at National Park Service Library, Longmire, Washington], 9 p.

Hausback, B.P., and Swanson, D.A., 1990, Record of prehistoric debris avalanches on the north flank of Mount St. Helens Volcano, Washington: Geoscience Canada, v. 17, p. 142-145.

Hayashi J.N., and Self, S., 1992, A comparison of pyroclastic flow and debris avalanche mobility: Geophysical Research, v. 97, p. 9063-9071.

Heim A., 1932, Bergsturz und Menschenleben: Deutsch. Geol. Gesell. Zeitschr., v. 34, p. 74--115.

Hoblitt, R.P., Walder, J.S., Driedger, C.L., Scott, K.M., Pringle, P.T., and Vallance, J.W., 1998, Volcanic hazards from Mount Rainier, Washington-Revised 1998: U.S. Geological Survey Open-File Report 98-428, 11 p.

Hsü, K.J., 1975, Catastrophic debris streams (sturzstroms) generated by rockfalls: Geological Society of America Bulletin, v. 86, p. 129-140.

Hyde, J.H., and Crandell, D.R., 1978, Postglacial volcanic deposits at Mount Baker, Washington, and potential hazards from future eruptions: U.S. Geological Survey Professional Paper 1022-C, $17 \mathrm{p}$.

INGEOMINAS (de Colombia), 1995a, El sismo del 6 de junio de 1994: I Seminario de Sismotectonica de Colombia, Memorias, Bogotá, 5 p.

— 1995b, El sismo de Paez, Cauca, 6 de junio de 1994: Video produced by Instituto de Investigaciones en Geociencias, Minería y Química, Bogotá.

Inokuchi, T., 1985, The Ontake rock slide and debris avalanche caused by the NaganokenSeibu earthquake, 1984: Proceedings, IVth International Conference and Field Workshop on Landslides, Toyko, unpaginated. , 1989, Characteristics of volcanic debris avalanches: (Japan) National Research Council for Disaster Prevention, Technology for Disaster Prevention, v. 13, p. 157-180. 
Instituto Geológico de México, 1922, Memoria relativa al terremoto Mexicano del 3 de enero de 1920, Boletín Numero 38, 106 p.

Ishihara, K., and Nakamura, S., 1987, Landslides in mountain slopes during the Ecuador earthquake of March 5, 1987, in Karasudhi, P., Nutalaya, P., and Chiu, A., US-Asia Conference on Engineering for Mitigation Natural Hazards Damage, Bangkok: Proceedings, p. C6-1 - C6-11.

Iverson, R.M., 1997, The physics of debris flows: American Geophysical Union, Reviews of Geophysics, v. 35, p. 245-296.

Iverson, R.M., Reid, M.E., and LaHusen, R.G., 1997, Debris flow mobilization from landslides: Annual Review of Earth and Planetary Sciences, v. 25.

Iverson, R.M., Schilling, S. P., and Vallance, J.W., 1998, Objective delineation of lahar hazard zones: Geological Society of America Bulletin, v. 110 , p. $972-984$.

Johnson, A.M., 1984, Debris flow (with contributions by Rodine, J.R.,), in Brunsden, D., and Prior, D.B., eds., Slope instability: New York, John Wiley and Sons, Ltd., p. 257-361.

Johnson, R.W., 1987, Large-scale volcanic cone collapse: the 1988 failure of Ritter volcano, and other examples from Papua New Guinea: Bulletin of Volcanology, v. 49, p. 669-679.

Keefer, D.K., 1984, Landslides caused by earthquakes: Geological Society of America Bulletin, v. 95, p. 406-421.

Kellerhals, R., and Bray, D.I., 1971, Sampling procedures for coarse fluvial sediments: Proceedings of American Society of Civil Engineers, Journal of the Hydraulics Division, v. 97, no. HY8, p. 1165-1180.

Kobayashi, Y., 1997, A mechanism facilitating long-runout rock avalanches (abs): International Association of Volcanology and Chemistry of the Earth's Interior, General Assembly, Jan. 19-24, 1997, Puerto Vallarta, Abstracts, p. 113.

LaHusen, R.G., 1998, Detecting debris flows using ground vibrations: U.S. Geological Survey Fact Sheet 236-96, 2 p.

Landim, P.M.B., and Frakes, L.A., 1968, Distinction between tills and other diamictons based on textural characteristics: Journal of Sedimentary Petrology, v. 38, p. 1213-1223.
Li, T., 1983, A mathematical model for predicting the extent of a major rockfall: Zeitschrift fur Geomorphologie, N.F., Band 27, Heft 24, p. 473-484.

Lockhart, A.B., Ewart, J.W., and Miller, C.D., 1998, The continuing need for scientists on-site during volcanic crises (abs.): Eos, v. 79, no. 45, p. 974.

López, D.L., and Williams, S.N., 1993, Catastrophic volcanic collapse: relation to hydrothermal processes: Science, v. 260, p. 1794-1796.

MacPhail, D.D., 1973, The geomorphology of the Río Teno lahar, Central Chile: Geographical Review, v. 63, p. 517-532.

McDowell, B., and Fletcher, J.E., 1962, Avalanche!: National Geographic Magazine, v. 121, p. 855--880.

Major, J.J., Iverson, R.M., McTigue, D.F., Macias, S., and Fiedorowicz, B.K., 1997, Geothechnical properties of debris-flow sediments and slurries, in Chen, C.L., ed., Debris-flow hazard mitigation: mechanics, prediction, and assessment: Proceedings of ASCE International Conference, Aug. 7-9, San Francisco

Major, J.J., and Newhall, C.R., 1989, Snow and ice perturbation during historical volcanic eruptions and the formation of lahars and floods-a global review: Bulletin of Volcanology, v. 52, p. 1-27.

Malone, S.D., 1996, Volcanic earthquake hazards in the Pacific Northwest (abs.): Geological Society of America Cordilleran Section Meeting, Portland, Oregon, Abstracts with Programs, p. 88.

Malone, S., and Moran, S., 1997, Deep long-period earthquakes in the Washington Cascades (abs.): Eos, v. 78, no. 46, p. F438.

Martínez, J.M., Avila, G., Agudelo, A., Schuster, R.L., Casadevall, T.J., and Scott, K.M., 1995, Landslides and debris flows triggered by the 6 June 1994 Paez earthquake, southwestern Colombia: Landslide News, no. 9, p. 13-15.

Melosh, H.J., 1987, The mechanics of large rock avalanches, in Costa, J.E., and Wieczorek, G.F. eds., Debris flows/avalanches: process, recognition, and mitigation: Geological Society of America Reviews in Engineering Geology, v. VII, p. 41-49.

Migale, L.S., Milone, A., 1998, Colate di Fango in terreni piroclastici della Campania-primi dati 
della ricerca storica: Rassegna Storica

Salernitana, v. XV (2), p. 235-271.

Miller, C.D., 1988, Development of volcanichazard-zonation maps for the Cascade Range,

Northwestern United States: Kagoshima International Conference on Volcanoes, 1988, Proceedings, p. 400-403.

Morales, B., 1966, The Huascarán avalanche in the Santa valley, Peru: International Symposium on Scientific Aspects of Snow and Ice Avalanches, International Association of Scientific Hydrology, pub. n. 69, p. 304-315.

Moran, S.C., 1997, Three-dimensional P-wave velocity structure in the Greater Mount Rainier Area from local earthquake tomography: Seattle, University of Washington, Ph.D. dissertation, $168 \mathrm{p}$.

Nakamura, Y., 1978, Geology and petrology of Bandai and Nekoma volcanoes: Tohoku University Science Reports, Series 3, v. 14, p. 67-119.

Nakamura, Y., and Glicken, H., 1997, Debris avalanche deposits of the 1888 eruption, Bandai Volcano, in Bandai Volcano-recent progress of hazard prevention: National Research Institute for Earth Science and Disaster Prevention, Japan Science and Technology Agency, 308 p.

Naranjo, J.A., and Francis, P., 1987, High-velocity debris avalanche at Lastarria volcano in the north Chilean Andes: Bulletin of Volcanology, v. 49 , p. $509-514$.

Naranjo, J.A., Scott, K.M., and Hildreth, E.W., 1997, Highly mobile catastrophic debris avalanche of Planchón-Peteroa volcanic complex, southern Andes, central Chile (abs.): IAVCEI General Assembly, Puerto Vallarta, Abstracts, p. 107.

Neall, V.E., 1976, Lahars as major geological hazards: Bulletin of the International Association of Engineering Geology, n. 14, p. 233-240.

- 1979, Sheets P19, P20, and P21 New Plymouth, Egmont, and Manaia ( $1^{\text {st }}$ ed.), "Geological Map of New Zealand." 3 maps and notes (36 p.) New Zealand Department of Scientific and Industrial Research, Wellington. 1996, Hydrological disasters associated with volcanoes, in Singh, V.P., ed., Hydrology of disasters: Norwell, Massachusetts, Kluwer Academic Publishers, p. 395-425.

Nelson, L.M., 1987, Flood characteristics for the Nisqually River and susceptibility of Sunshine
Point and Longmire facilities to flooding in Mount Rainier National Park, Washington: U.S. Geological Survey Open-File Report 86-4179, $18 \mathrm{p}$.

Newhall, C.G., and Punongbayan, R.S., eds., 1996, Fire and mud-eruptions and lahars of Mount Pinatubo, Philippines: Seattle, University of Washington Press, 1126 p.

Nieto, A.S., Schuster, R.L., and Plaza-Nieto, G., 1991, Mass wasting and flooding, in Schuster, R.L., ed., The March 5, 1987, Ecuador earthquakes-Mass wasting and socioeconomic effects: Natural Disaster Studies, Natural Academy of Sciences, National Academy Press, Washington, D.C., v. 5, p. 51-82.

Norris, R.D., 1994, Seismicity of rockfalls and avalanches at three Cascade volcanoes: implications for seismic detection of hazardous mass movements: Seismological Society of America Bulletin, v. 84 , p. 1,925-1,939.

Oddone, E., 1921, La catastrofe sismica al Messico addi 3 gennaio 1920: Zeitschrift für Vulkanologie, Band VI, Heft 2, p. 88-96.

Okuda, S., Suwa, H., Okunishi, K., Yokoyama, K., and Nakano, M., 1980, Observations on the motion of a debris flow and its geomorphological effects: Zeitschrift für Geomorphologie, Suppl., Bd. 35, p. 142-163.

Orsi, G., Di Vito, M., and Isaia, R., 1988, Volcanic hazards and risk in the Parthenopean megacity: Field Excurson Guidebook, International Meeting, Cities on Volcanoes, Rome and Naples (Italy), June 28 to July 4, 1998, 206 p.

Pain, C.F., 1972, Characteristics and geomorphic effects of earthquake-initiated landslides in the Adelbert Range, Papua New Guinea: Engineering Geology, v. 6, p. 261-274.

Palgarín, B., 2000, Depósitos masivos del Plesitoceno tardío asociados al colapso del flanco sur del Volcán Nevado del Huila, Colombia: Tesís de Maestría, National Autonomous University of Mexico, Mexico City, 135 p.

Palmer, B.A., Alloway, B.V., and Neall, V.E., 1991, Volcanic debris-avalanche deposits in New Zealand-lithofacies organization in confined, wet-avalanche flows, in Fisher, R.V., and Smith, G.A., Sedimentation in Volcanic Settings, SEPM Special Publication n. 45, p. 89-98.

Palmer, B.A., and Neall, V.E., 1989, The Murimotu Formation-9500 year old deposits of a debris 
avalanche and associated lahars, Mount Ruapehu, North Island, New Zealand: New Zealand Journal of Geology and Geophysics, v. 32, p. $477-486$.

Pareschi, M.T., 1996, Physical modeling of eruptive phenomena: lahars, in Scarpa, R., and Tilling, R.I., Monitoring and mitigation of volcanic hazards, Berlin, Springer-Verlag, p. 463-489.

Pareschi, M.T., Favalli, M., Zanchetta, G., Cavarra, L., and Santacroce, R., 1998, May 5, 1998 secondary lahars of Vesuvius (abs.): International Meeting, Cities on Volcanoes, International Association of Volcanology and Chemistry of the Earth's Interior, Abstracts with Programs, p. 108.

Pareschi, M.T., Favalli, M., Giannini, F., Sulpizio, R., Zanchetta, G., and Santacroce, R., 2000, May 5, 1998 debris flows in circum-Vesuvian areas (southern Italy): Insights for hazard assessment: Geology, v. 28, p. 639-642.

Pierson, T.C., 1985, Initiation and behavior of the 1980 Pine Creek and Muddy River lahars, Mount St. Helens, Washington: Geological Society of America Bulletin, v. 96, p. 1056-1069.

- 1997, Transformation of water flood to debris flow following the eruption-triggered transient-lake breakout from the crater on March 19, 1982, in Pierson, T.C., ed., Hydrologic consequences of hot-rock/snowpack interactions at Mount St. Helens volcano, Washington, 1982-84: U.S. Geological Survey Open-File Report 96-179, p. 19-36. , 1998, An empirical method for estimating travel times for wet volcanic mass flows: Bulletin of Volcanology, v. 60, p. 98-109.

Pierson, T.C., and Costa, J.E., 1987, A rheologic classification of subaerial sediment-water flows: Geological Society of America Reviews in Engineering Geology, Volume VII, p. 1-12.

Pierson, T.C., Janda, R.J., Thouret, J.-C., Borrero, C.A., 1990, Perturbation and melting of snow and ice by the 13 November 1985 eruption of Nevado del Ruiz, Colombia, and consequent mobilization, flow and deposition of lahars: Journal of Volcanology and Geothermal Research, v. 41, p. 17-66.

Pierson, T.C., Janda, R.J., Umbal, J.V., and Daag. A.S., 1992, Intermediate and long-term hazards from lahars and excess sedimentation in rivers draining Mt. Pinatubo, Philippines: U.S. Geological Survey Water-Resources Investigations Report 92-4039, 35 p.

Pierson, T.C., and Scott, K.M., 1985, Downstream dilution of a lahar: transition from debris flow to hyperconcentrated streamflow: Water Resources Research, v. 21, p. 1511-1524.

Pierson, T.C., and Waitt, R.B., 1997, Introduction, in Pierson, T.C., ed., Hydrologic consequences of hot-rock/snowpack interactions at Mount St. Helens volcano, Washington, 1982-84, U.S. Geological Survey Open-File Report 96-179, p. 1-8.

Plafker, G., and Ericksen, G.E., 1975, Nevados Huascarán avalanches, Peru, in Voight, B., ed, Rockslides and avalanches: Natural Phenomena, v. 1, Elsevier, Amsterdam, p. 277-314.

Post, A., 1967, Effects of the March 1964 Alaska earthquake on glaciers: U.S. Geological Survey Professional Paper 544-D, $42 \mathrm{p}$

Pringle, P.T., Schuster, R.L., and Logan, R.L., 1998, New radiocarbon ages of major landslides in the Cascade Range, Washington: Washington Geology, v. 26, p. 31-39.

Pulgarín, B., 2000, Depósitos masivos del Pleistoceno tardía asociados al colapsa del flanco sur del Volcán Nevado del Huila, Colombia: Tesís de Maestría, National Autonomous University of Mexico, Mexico City, 135 p.

Pulgarín, B., and Macías, J.L., 1998, Debris avalanche at Nevado del Huila volcanic complex, Colombia (abs.): Sexta Reunion International, Volcán de Colima, Abstracts, unpaginated.

Red Seismológica Nacional de Colombia, 1994, El Seismo de Paéz (Cauca) del 6 de Junio de 1994: Boletín Mensual de Seismos, INGEOMINAS, Santafé de Bogotá, Colombia, v. 2, no. 6, p. 13.

Reid, M.E., Christian, S.B., Brien, D.L., and Sisson, T., 1999, Gravitational stability of stratovolcanoes (abs.): EOS, American Geophysical Union Transactions, v. 80, p. 1151.

Rodríguez, S.R., and Komorowski, J.K., 1997, Las Cumbres volcanic complex, eastern TransMexican Volcanic Belt (TMVB), geological evolution and characteristics of the main pyroclastic deposits (abs.): International Association of Volcanology and Chemistry of the Earth's Interior, General Assembly, Puerto Vallarta, Abstracts, p. 154. 
Schilling, S.P., 1998, LAHARZ: GIS programs for automated mapping of lahar-inundation hazard zones: U.S. Geological Survey Open-File Report 98-638, $80 \mathrm{p}$.

Schilling, S.P., and Iverson, R.I., 1998, Automated hazard maps for Cascade volcanoes created using a GIS (abs.): International Meeting, Cities on Volcanoes, International Association of Volcanology and Chemistry of the Earth's Interior, Rome and Naples, Program and Abstracts, p, 122.

Schuster, R.L., 2001, Socioeconomic and environmental impacts of landslides in the western hemisphere: Poceedings, $3^{\text {rd }}$ Panamerican Symposium on Landslides, Cartagena, Colombia, July 30-August 3.

Schuster, R.L., and Crandell, D.R., 1984, Catastrophic debris avalanches from volcanoes: Proceedings IV Symposium on Landslides, Toronto, v. 1, p. 567-572.

Schuster, R.L., Logan, R.L., and Pringle, P.T., 1992, Prehistoric rock avalanches in the Olympic Mountains, Washington: Science, v. 258, p. 1620-1621.

- Logan, R.L., and Pringle, P.T., 1995, Prehistoric rock avalanches of the Olympic Peninsula - chronology and neotectonic significance (abs.): Geological Association of Canada/ Mineralogical Association of Canada Annual Meeting, Final Program and Abstracts, v. 20, p. A-95.

Schuster, R. L., Nieto, A.S., and O'Rourke, T.D., Crespo, E., and Plaza-Nieto, G., 1996, Mass wasting triggered by the 5 March 1987 Equador earthquakes: Engineering Geology, v. 42, p. 1-23.

Scott, K.M., 1988a, Origins, behavior, and sedimentology of lahars and lahar-runout flows in the Toutle-Cowlitz River system: U.S. Geological Survey Professional Paper 1447-A, 74 p.

$\longrightarrow, 1988 \mathrm{~b}$, Origin, behavior, and sedimentology of prehistoric lahars at Mount St. Helens, Washington: Geological Society of America Special Paper 229, p. 23-36.

1997, The dichotomy of cohesive (muddy) and noncohesive (granular) lahars-implications of deposit texture for hazard assessment (abs.): International Association of Volcanology and Chemistry of the Earth's Interior General Assembly, Puerto Vallarta, Abstracts, p. 106.
2000, Precipitation-triggered debris-flow at Casita volcano, Nicaragua: Implications for mitigation strategies in volcanic and tectonically active steeplands, in Wieczorek, G.F., and Naeser, N.D., Debris-flow hazards mitigation, mechanics, prediction, and assessment: Proceedings of the Second International Conference on Debris-Flow Hazards Mitigation, Taipei, Taiwan, 16-18 August, 2000: p. 3-13.

Scott, K.M., and Driedger, C.L., 1998, Education for Self Warning and Evacuation (ESWEV)saving lives from catastrophic lahars and nonvolcanic debris flows (abs.): International Meeting, Cities on Volcanoes, International Association of Volcanology and Chemistry of the Earth's Interior, Abstracts with Programs, p. 124.

Scott, K.M., and Janda, R.J., 1987, Multiple origins of catastrophic lahars at Cascade Range volcanoes-probabilities of precursor events, and hazards in downstream areas (abs): Hawaii Symposium on How Volcanoes Work, Hilo, January 19-25, 1987, p. 229.

Scott, K.M., Pringle, P.T., and Vallance, J.W., 1992, Sedimentology, behavior, and hazards of debris flows at Mount Rainier, Washington: U.S. Geological Survey Open-File Report 90-385, $106 \mathrm{p}$.

Scott, K.M., and Vallance, J.W., 1995, Debris flow, debris avalanche, and flood hazards at and downstream from Mount Rainier, Washington: U.S. Geological Survey Hydrologic Investigations Atlas 729: 2 Sheets and Accompanying Pamphlet.

Scott, K.M., Vallance, J.W., and Pringle, P.T., 1995, Sedimentology, behavior and hazards of debris flows at Mount Rainier, Washington: U.S. Geological Survey Professional Paper $1547,56 \mathrm{p}$.

Scott, K.M., Wolfe, E.W., and Driedger, C.L., 1998, Mount Rainier-living with perilous beauty: U.S. Geological Survey Fact Sheet 065-97, 4 p.

Scott, K.M., Hildreth, W., and Gardner, C. A., 2000, Mount Baker-Living with an active volcano: U.S. Geological Survey Fact Sheet 059-00, 4 p.

Sharp, R.P., and Nobles, L.H., 1953, Mudflow of 1941 at Wrightwood, southern California: Geological Society of America Bulletin v. 64, p. 547-560. 
Sheridan, M.F., and Macias, J.L., 1995, Estimation of risk probability for gravity-driven pyroclastic flows at Volcan Colima, Mexico: Journal of Volcanology and Geothermalk Research, v. 66, p. 251-256.

Sheridan, M.F., and Kover, T., 1996, FLOW3D: A computer code for simulating rapid, openchannel flows: Proceedings, Workshop on the Technology of Disaster Prevention Against Local Severe Storms, Norman, Oklahoma, p. $155-163$.

Sheridan, M.F., Siebe, C., Bonnard, C., Strauch, W., Navarro, M., Cruz Calero, J., and Buitrago Trujillo, N., 1998, Reporte sobre la avalanche y el flujo de agua con sedimentos, in el volcán Casita, Nicaragua, disparados por el huracán Mitch: in INETER, Las Lluvias del Siglo en Nicaragua; Managua, Anexo I, p. 141-143.

Shreve, R.L., 1968, The Blackhawk landslide: Geological Society of America Special Paper $108,47 \mathrm{p}$.

Siebe, C., Komorowski, J.C., and Sheridan, M.F., 1992, Morphology and emplacement collapse of an unusual debris avalanche deposit at Jocotitlán Volcano, Central Mexico: Bulletin of Volcanology, v. 54, p. 573-589.

Siebe, C., Abrams, M., and Sheridan, M.F., 1993, Major Holocene block-and-ash fan at the western slope of ice-capped Pico de Orizaba volcano, Mexico: implications for future hazards: Journal of Volcanology and Geothermal Research, v. 59, p. 1-33.

Siebe, C., Abrams, M., Macías, J.L., and Obenholzner, J., 1996, Repeated volcanic disasters in Prehispanic time at Popocatépetl, central Mexico: Past key to the future?: Geology, v. 24, p. 399-402.

Siebert, L., 1984, Large volcanic debris avalanches: characteristics of source areas, deposits, and associated eruptions: Journal of Volcanology and Geothermal Research, v. 22, p. 163-197.

$\longrightarrow, 1996$, Hazards of large volcanic debris avalanches and associated eruptive phenomena, in Scarpa, R., and Tilling, R.I., eds., Monitoring and mitigation of volcano hazards: Berlin, Springer-Verlag, p. 541-572.

Siebert, L., Glicken, H., and Ui, T., 1987, Volcanic hazards from Bezymianny- and Bandai-type eruptions: Bulletin of Volcanology, v. 49 , p. $435-459$.
Simkin, T., Siebert, L., and Blong, R., 1998, Historical patterns in volcanic eruptions (abs.): Eos, v. 79, no. 45, p. 973.

Singh, S.K.,, Rodríguez, M., and Espíndola, J.M., 1984, A catalog of shallow earthquakes of Mexico from 1900 to 1984: Seismological Society of America Bulletin, v. 74, p. 267-279.

Sisson, T.W., 1995, An overview of the geology of Mount Rainier's volcanic edifice (abs.): Eos, v. 76 , no. 46 , p. 643 .

Sisson, T.W., and Lanphere, M.A., 1997, The growth of Mount Rainier, Cascade Arc, USA (abs.): International Association of Volcanology and Chemistry of the Earth's Interior General Assembly, Puerto Vallarta, Abstracts, p. 5.

Sisson, T.W., Vallance, J.W., and Pringle, P.T., 2001, Progress made in understanding Mount Rainier's hazards: EOS, v. 82, no. 9 , p. 113-120.

Stoopes, G.R., and Sheridan, M.F., 1992, Giant debris avalanches from the Colima Volcanic Complex, Mexico: Implications for long-runout landslides $(>100 \mathrm{~km})$ and hazard assessment: Geology, v. 20, p. 299-302.

Tilling, R.I., and Eichelberger, J.C., 1998, Reducing volcanic risk in the $21^{\text {st }}$ century: context and challenges (abs.): Eos, v. 70, no. 45, p. 972

Ui, T., 1981, Dry avalanche-mechanisms of eruption, transportation, and deposition (abs): International Association of Volcanology and Chemistry of the Earth's Interior, Symposium on Arc Volcanism, Tokyo and Hakone, Abstracts, p. 388-389.

- 1983, Volcanic dry avalanche depositsidentification and comparison with nonvolcanic debris stream deposits: Journal of Volcanology and Geothermal Research, v. 18, p. 135-150.

Ui, T., Yamamoto, H., and Suzuki-Kamata, K., 1986, Characterization of debris avalanche deposits in Japan: Journal of Volcanology and Geothermal Research, p. 231-243.

United Nations Department of Humanitarian Affairs, 1994, Colombia-earthquake: DHA News, May-August, p. 39.

Vallance, J.W., 1995, Holocene tephras and history of Mount Rainier volcano (abs.): Eos, v.76, no. 46 , p. 644 . 2000, Lahars, in Sigurdsson, H., Houghton, B., McNutt, S.R., Rymer, H., and Stix, J., eds., 
Encyclopedia of Volcanoes: New York, Academic Press, p. 601-616.

Vallance, J.W., and Donoghue, S., 1999, Holocene eruptive history of Mount Rainier (abs.): Northwest Scientific Association, 1999 Annual Meeting, Tacoma, Washington, Program and Abstract Listings, p. 52.

Vallance, J.W., and Scott, K.M., 1997, The Osceola Mudflow from Mount Rainier: sedimentology and hazard implications of a huge clay-rich debris flow: Geological Society of America Bulletin, v. 109, p. 143-163.

van Wyk de Vries, B., and Francis, P.W., 1997, Catastrophic at stratovolcanoes induced by gradual volcano spreading: Nature, v. 387, p. 387-390.

Van Wyk de Vries, B., Kerle, N., and Petley, D., 2000 A sector collapse forming at Casita volcano, Nicaragua: Geology, v. 28, p. 167-170.

Varnes, D.J., 1978, Slope movement types and processes, in Schuster, R.L., and Krizek, R.J., eds., Landslides, analysis and control: National Research Council, Transportation Research Board, Special Report 176, p. 11-33.

Voight, B., 1988, Countdown to catastrophe: Earth and Mineral Sciences, v. 57, p. 17-30.

_ 1990, The 1985 Nevado del Ruiz volcano catastrophe: anatomy and retrospection: Journal of Volcanology and Geothermal Research, v. 42, p. 151-188.

— 1996, The management of volcano emergencies: Nevado del Ruiz, in Scarpa, R., and Tilling, R.I., eds., Monitoring and mitigation of volcanic hazards: Berlin, Springer-Verlag, p. 719-769.

Voight, B., Janda, R.J., Glicken, H., and Douglass, P.M., 1983, Nature and mechanics of the Mount St. Helens rockslide-avalanche of 18 May 1980: Geotechnique, v. 33, p. 243-273.

Wadge, G., Francis, P.W., and Ramirez, C.F., 1995, The Socompa collapse and avalanche event: Journal of Volcanology and Geothermal Research, v. 66, p. 309-336.
Walder, J.S., 1997, Nature of depositional contacts between pyroclastic deposits and snow or ice, in Pierson, T.C., ed., Hydrologic consequences of hot-rock/snowpack interactions at Mount St. Helens volcano, Washington, 1982-84: U.S. Geological Survey Open-File Report 96-179, p. 9-18.

_ 2000a, Pyroclast/snow interactions and thermally driven slurry formation. Part 1 : Theory for monodisperse grain beds: Bulletin of Volcanology, v. 62, p. 105-118.

$\longrightarrow, 2000 \mathrm{~b}$, Pyroclast/snow interactions and thermally driven slurry formation. Part 2 : Experiments and theoretical extension to polydisperse tephra: Bulletin of Volcanology, v. 62 , p. $119-129$.

Wallmann, P.C., Mahood, G.A., and Pollard, D.D., 1988, Mechanical models for correlation of ring-fracture eruptions at Pantelleria, Strait of Sicily, with glacial sea-level drawdown: Bulletin Volcanologique, v. 50, p. 327-339.

Watters, R.J., and Delahaut, W.D., 1995, Effect of argillic alteration on rock mass stability: Geological Society of America Reviews in Engineering Geology, v. X, p. 139-150.

Watters, R.J., Zimbelman, D.R., Bowman, S.D., and Crowley, J.K., 2000, Rock mass strength of fresh and altered rocks and significance to edifice stability, Cascade Range volcanoes: Journal of Pure and Applied Geophysics, v. 157, p. 957-976.

Wright, C., and Mella, A., 1963, Modifications to the soil pattern of South-Central Chile resulting from seismic and associated phenomena during the period May to August 1960: Seismological Society of America Bulletin, v. 53, no. 6, p. 1367-1402. 


\section{Availability of Publications of the U.S. Geological Survey}

Order U.S. Geological Survey (USGS) publications by calling the toll-free telephone number 1-888-ASK-USGS or contacting the offices listed below. Detailed ordering instructions, along with prices of the last offerings, are given in the current-year issues of the catalog "New Publications of the U.S. Geological Survey."

\section{Books, Maps, and Other Publications}

\section{By Mail}

Books, maps, and other publications are available by mail from-

USGS Information Services

Box 25286, Federal Center

Denver, CO 80225

Publications include Professional Papers, Bulletins, WaterSupply Papers, Techniques of Water-Resources Investigations, Circulars, Fact Sheets, publications of general interest, single copies of permanent USGS catalogs, and topographic and thematic maps.

\section{Over the Counter}

Books, maps, and other publications of the U.S. Geological Survey are available over the counter at the following USGS Earth Science Information Centers (ESIC's), all of which are authorized agents of the Superintendent of Documents:

- Anchorage, Alaska-Rm. 101, 4230 University Dr.

- Denver, Colorado-Bldg. 810, Federal Center

- Menlo Park, California-Rm. 3128, Bldg. 3, 345 Middlefield Rd.

- Reston, Virginia-Rm. 1 C402, USGS National Center, 12201 Sunrise Valley Dr.

- Salt Lake City, Utah-2222 West, 2300 South

- Spokane, Washington-Rm. 135, U.S. Post Office Building, 904 West Riverside Ave.

- Washington, D.C.-Rm. 2650, Main Interior Bldg., 18th and C Sts., NW.

Maps only may be purchased over the counter at the following USGS office:

- Rolla, Missouri-1400 Independence Rd.

\section{Electronically}

Some USGS publications, including the catalog "New Publications of the U.S. Geological Survey" are also available electronically on the USGS's World Wide Web home page at http://www.usgs.gov

\section{Preliminary Determination of Epicenters}

Subscriptions to the periodical "Preliminary Determination of Epicenters" can be obtained only from the Superintendent of Documents. Check or money order must be payable to the Superintendent of Documents.
Order by mail from-

Superintendent of Documents

Government Printing Office

Washington, DC 20402

\section{Information Periodicals}

Many Information Periodicals products are available through the systems or formats listed below:

\section{Printed Products}

Printed copies of the Minerals Yearbook and the Mineral Commodity Summaries can be ordered from the Superintendent of Documents, Government Printing Office (address above). Printed copies of Metal Industry Indicators and Mineral Industry Surveys can be ordered from the Center for Disease Control and Prevention, National Institute for Occupational Safety and Health, Pittsburgh Research Center, P.O. Box 18070, Pittsburgh, PA 15236-0070.

\section{Mines FaxBack: Return fax service}

1. Use the touch-tone handset attached to your fax machine's telephone jack. (ISDN [digital] telephones cannot be used with fax machines.)

2. Dial (703) 648-4999.

3. Listen to the menu options and punch in the number of your selection, using the touch-tone telephone.

4. After completing your selection, press the start button on your fax machine.

\section{CD-ROM}

A disc containing chapters of the Minerals Yearbook (1993-95), the Mineral Commodity Summaries (1995-97), a statistical compendium (1970-90), and other publications is updated three times a year and sold by the Superintendent of Documents, Government Printing Office (address above).

\section{World Wide Web}

Minerals information is available electronically at http://minerals.er.usgs.gov/minerals/

\section{Subscription to the catalog "New Publications of the U.S. Geological Survey"}

Those wishing to be placed on a free subscription list for the catalog "New Publications of the U.S. Geological Survey" should write to-

U.S. Geological Survey

903 National Center

Reston, VA 20192 


\section{Selected Series of U.S. Geological Survey Publications}

\section{Books and Other Publications}

Professional Papers report scientific data and interpretations of lasting scientific interest that cover all facets of USGS investigations and research.

Bulletins contain significant data and interpretations that are of lasting scientific interest but are generally more limited in scope or geographic coverage than Professional Papers.

Water-Supply Papers are comprehensive reports that present significant interpretive results of hydrologic investigations of wide interest to professional geologists, hydrologists, and engineers. The series covers i nvestiga-tions in all phases of hydrology, including hydrogeology, availability of water, quality of water, and use of water.

Circulars are reports of programmatic or scientific information of an ephemeral nature; many present important scientific information of wide popular interest. Circulars are distributed at no cost to the public.

Fact Sheets communicate a wide variety of timely information on USGS programs, projects, and research. They commonly address issues of public interest. Fact Sheets generally are two or four pages long and are distributed at no cost to the public.

Reports in the Digital Data Series (DDS) distribute large amounts of data through digital media, including compact disc-read-only memory (CD-ROM). They are high-quality, interpretive publications designed as self-contained packages for viewing and interpreting data and typically contain data sets, software to view the data, and explanatory text.

Water-Resources Investigations Reports are papers of an interpretive nature made available to the public outside the formal USGS publications series. Copies are produced on request (unlike formal USGS publications) and are also available for public inspection at depositories indicated in USGS catalogs.

Open-File Reports can consist of basic data, preliminary reports, and a wide range of scientific documents on USGS investigations. Open-File Reports are designed for fast release and are available for public consultation at depositories.

\section{Maps}

Geologic Quadrangle Maps (GQ's) are multicolor geologic maps on topographic bases in 7.5- or 15-minute quadrangle formats (scales mainly 1:24,000 or 1:62,500) showing bedrock, surficial, or engineering geology. Maps generally include brief texts; some maps include structure and columnar sections only.

Geophysical Investigations Maps (GP's) are on topographic or planimetric bases at various scales. They show results of geophysical investigations using gravity, magnetic, seismic, or radioactivity surveys, which provide data on subsurface structures that are of economic or geologic significance.
Miscellaneous Investigations Series Maps or Geologic Investigations Series (I's) are on planimetric or topographic bases at various scales; they present a wide variety of format and subject matter. The series also incudes 7.5minute quadran-gle photogeologic maps on planimetric bases and planetary maps.

\section{Information Periodicals}

Metal Industry Indicators (MII's) is a free monthly newsletter that analyzes and forecasts the economic health of ve metal industries with composite leading and coincident indexes: primary metals, steel, copper, primary and secondary aluminum, and aluminum mill products.

Mineral Industry Surveys (MIS's) are free periodic statistical and economic reports designed to provide timely statistical data on production, distribution, stocks, and consumption of significant mineral commodities. The surveys are issued monthly, quarterly, annually, or at other regular intervals, depending on the need for current data. The MIS's are published by commodity as well as by State. A series of international MIS's is also available.

Published on an annual basis, Mineral Commodity Summaries is the earliest Government publication to furnish estimates covering nonfuel mineral industry data. Data sheets contain information on the domestic industry structure, Government programs, tariffs, and 5-year salient statistics for more than 90 individual minerals and materials.

The Minerals Yearbook discusses the performance of the worldwide minerals and materials industry during a calendar year, and it provides background information to assist in interpreting that performance. The Minerals Yearbook consists of three volumes. Volume I, Metals and Minerals, contains chapters about virtually all metallic and industrial mineral commodities important to the U.S. economy. Volume II, Area Reports: Domestic, contains a chapter on the minerals industry of each of the 50 States and Puerto Rico and the Administered Islands. Volume III, Area Reports: International, is published as four separate reports. These reports collectively contain the latest available mineral data on more than 190 foreign countries and discuss the importance of minerals to the economies of these nations and the United States.

\section{Permanent Catalogs}

"Publications of the U.S. Geological Survey, 1879-1961" and "Publications of the U.S. Geological Survey, 1962-1970" are available in paperback book form and as a set of microfiche.

"Publications of the U.S. Geological Survey, 1971-1981" is available in paperback book form (two volumes, publications listing and index) and as a set of microfiche.

Annual supplements for 1982, 1983, 1984, 1985, 1986, and subsequent years are available in paperback book form. 

